\title{
Diverse Coordination Modes of Bidentate COC and Tridentate CNC Ligands Comprising 1,2,3-Triazol-5-ylidenes
}

\author{
Lewis C. Tolley, ${ }^{\dagger}$ Ian Strydom, ${ }^{\dagger}$ Wynand J. Louw, ${ }^{\ddagger}$ Manuel A. Fernandes, ${ }^{\dagger}$ Daniela I. Bezuidenhout, ${ }^{*}, \oplus$ \\ and Gregorio Guisado-Barrios*, ${ }^{*}(0)$ \\ ${ }^{\dagger}$ Molecular Sciences Institute, School of Chemistry, University of the Witwatersrand, Johannesburg 2050, South Africa \\ ${ }^{\ddagger}$ Department of Chemistry, University of Pretoria, Private Bag X20, Hatfield, 0028 Pretoria, South Africa \\ ${ }^{\S}$ Institute of Advance Materials (INAM), Centro de Innovación en Química Avanzada (ORFEO-CINQA). Universitat Jaume I, \\ Avenida Vicente Sos Baynat s/n, 12071 Castellon, Spain
}

\section{Supporting Information}

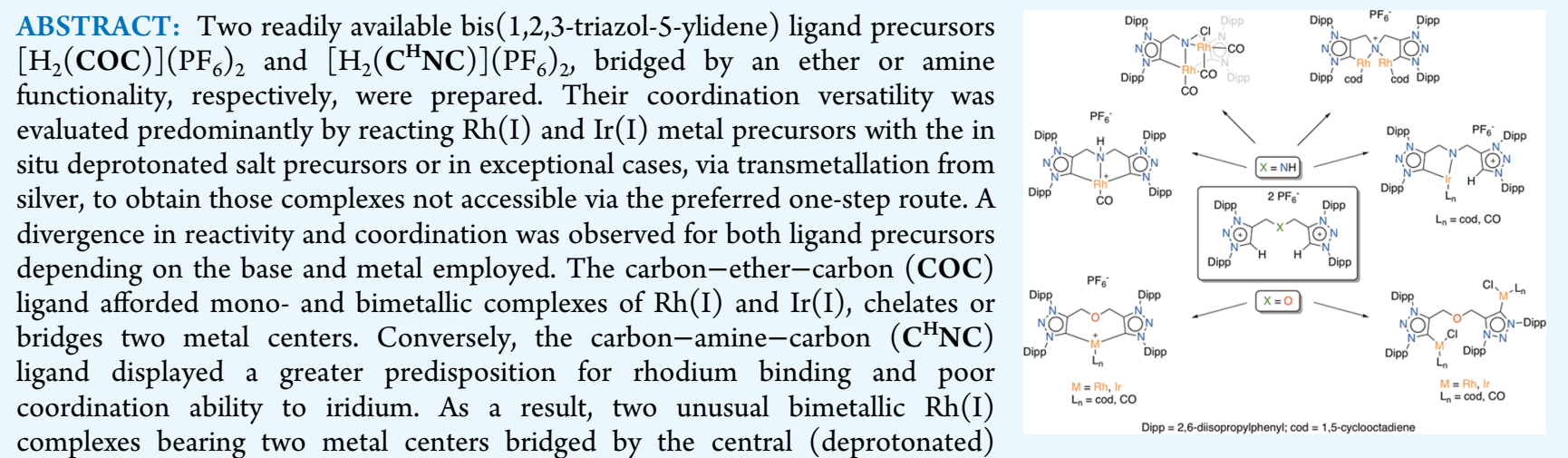
amido functionality, along with a monometallic $\mathrm{Rh}(\mathrm{I})$ containing the neutral amino-CNC pincer ligand were isolated. In contrast, only monometallic $\operatorname{Ir}(\mathrm{I})$ complexes bearing a pendant triazolium arm could be prepared.

\section{INTRODUCTION}

$\mathrm{N}$-heterocyclic carbene ligands (NHCs) have been widely used as ligands for the preparation of organometallic compounds, ${ }^{1}$ specifically in the arena of efficient homogeneous catalyst development. The continuous efforts to modify the electronic properties and modulate the substitution pattern (sequence and number of the heteroatoms) of the classical Arduengotype imidazolylidenes have led to the development of different NHC frameworks such as the cyclic(alkyl)(amino) carbenes ${ }^{2}$ and mesoionic carbenes (MICs). ${ }^{3}$ Among them, mesoionic 1,2,3-triazolylidene ligands have recently received considerable attention due to their intrinsic mesoionic character provisioning them as strong $\sigma$-donors. The particular advantage of this class of ligands is the potential for ligand-metal cooperativity combined with their synthetic versatility, giving access to readily available mono-, bi-, and tridentate ligands. ${ }^{4}$ In this context, the isolation of the first stable "click" chemistryderived mesoionic bis(triazolylidene) (i-bitz) bearing two carbene units directly bound to the $\mathrm{C} 4$ carbon of the triazolylidene and its related monometallic $[\mathrm{Rh}(\mathrm{i}-\mathrm{bitz})(\mathrm{cod})]-$ [OTf $]$ and $\left[\mathrm{Rh}(\mathrm{i}-\mathrm{bitz})(\mathrm{CO})_{2}\right][\mathrm{OTf}]$ complexes reported by Bertrand and co-workers ${ }^{5}$ spurred the development of several metal complexes based on poly(triazolylidene) ligands. Several examples, by varying the number of carbene moieties (two ${ }^{6}$ or three $^{7}$ ), the substituents at the N1 and N3 (alkyl or aryl) of the triazolylidene, as well the spacer or scaffold employed (flexible or rigid), have been reported since. We have recently isolated the potassium adduct of an anionic CNC bis(triazolylidene) pincer ligand based on a rigid carbazole scaffold, ${ }^{6 j}$ readily available upon deprotonation of the corresponding bistriazolium amine salt. Its coordination versatility and extraordinary electronic properties were demonstrated by the preparation of a range of complexes, ${ }^{6 \mathrm{~g}-\mathrm{j}}$ notably including reactive species such as the $\mathrm{Ni}(\mathrm{II})^{6 \mathrm{j}}$ and $\mathrm{Au}(\mathrm{III})$ hydrides $^{6 \mathrm{~g}}$ as well as $\mathrm{Rh}(\mathrm{I})$ oxygen adducts. ${ }^{6 i}$ Notwithstanding the significant catalytic implications demonstrated by related ancillary aliphatic pincer ligands, ${ }^{8}$ the number of metal complexes featuring poly(triazolylidene) ligands linked by a flexible aliphatic spacer bearing none or any additional functionality is still limited. ${ }^{9}$ Herein, we report the synthesis of readily available ether- and amine-bridged bis(triazolium) ligand precursors that were employed for the preparation of several mono- and binuclear rhodium and iridium complexes, including a $[(\mathrm{CNC}) \mathrm{Rh}(\mathrm{I})$ (CO)] metal complex containing an aliphatic CNC pincer ligand.

Received: February 23, 2019

Accepted: March 27, 2019

Published: April 4, 2019 
Scheme 1. Synthesis of Ligand Salt Precursors $\left[\mathrm{H}_{2}(\mathrm{COC})\right]\left(\mathrm{PF}_{6}\right)_{2}$ and $\left[\mathrm{H}_{2}\left(\mathrm{C}^{\mathrm{H}} \mathrm{NC}\right)\right]\left(\mathrm{PF}_{6}\right)_{2}$

$$
\text { (ipp }
$$

Scheme 2. Synthesis of Metal Complexes 1-5

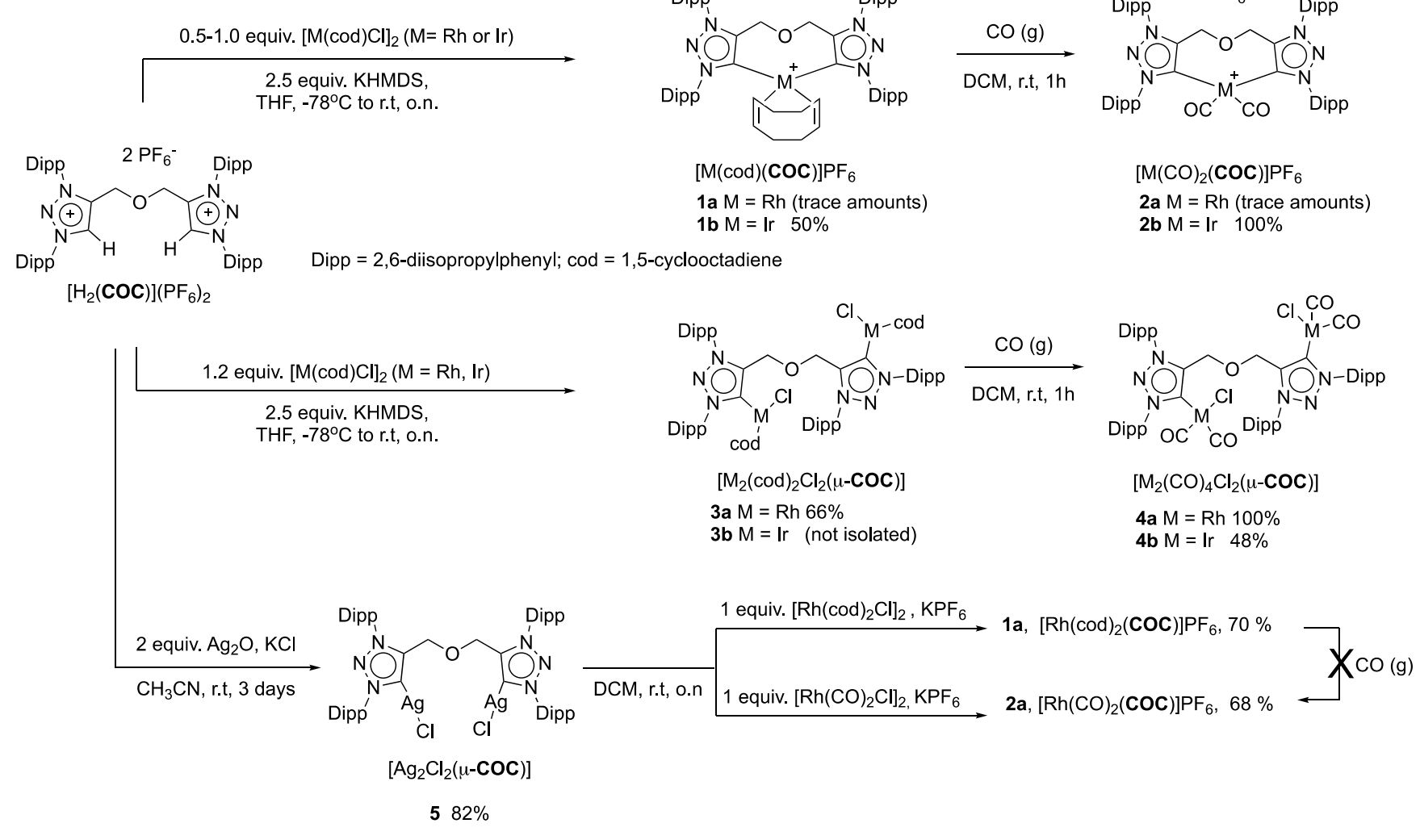

\section{RESULTS AND DISCUSSION}

The ether-bridged bistriazolium salt $\left[\mathrm{H}_{2}(\mathbf{C O C})\right]\left(\mathrm{PF}_{6}\right)_{2}$ was obtained in $87 \%$ yield by using an adapted version of a $1,3-$ dipolar cycloaddition between 1,3-bis-(2,6-diisopropylphenyl)triaz-1-ene and dipropargyl ether (Scheme 1). ${ }^{3 \mathrm{~d}}$ The aminobridged bistriazolium salt was prepared in two steps starting with a 1,3-dipolar cycloaddition between 1,3-bis-(2,6diisopropylphenyl)triaz-1-ene and $N$-(tert-butyloxy)carbonyl dipropargylamine that gives $\left[\mathrm{H}_{2}\left(\mathbf{C}^{\mathrm{Boc}} \mathrm{NC}\right)\right]\left(\mathrm{PF}_{6}\right)_{2}$, followed by a deprotection step involving the removal of the tertbutyloxycarbonyl (Boc) protecting group using a $3 \mathrm{~N}$ methanolic solution of hydrochloric acid to produce $\left[\mathrm{H}_{2}\left(\mathbf{C}^{\mathrm{H}} \mathbf{N C}\right)\right]\left(\mathrm{PF}_{6}\right)_{2}$ in $85 \%$ yield. ${ }^{9 \mathrm{e}}$ The detailed synthetic procedure and characterization data, including the $\mathrm{X}$-ray diffraction (XRD) crystal structures of $\left[\mathrm{H}_{2}(\mathbf{L})\right]\left(\mathrm{PF}_{6}\right)_{2}$ (with $\mathbf{L}=\mathbf{C O C}, \mathbf{C}^{\mathrm{Boc}} \mathbf{N C}$, and $\left.\mathbf{C}^{\mathrm{H}} \mathbf{N C}\right)$, are included in the Supporting Information (SI). The bistriazolium salts $\left[\mathrm{H}_{2}(\mathbf{C O C})\right]\left(\mathrm{PF}_{6}\right)_{2}$ and $\left[\mathrm{H}_{2}\left(\mathbf{C}^{\mathrm{H}} \mathbf{N C}\right)\right]\left(\mathrm{PF}_{6}\right)_{2}$ were selected as ligand precursors for the preparation of the corresponding $\mathrm{Rh}(\mathrm{I})$ and $\operatorname{Ir}(\mathrm{I})$ complexes.

We initially evaluated the coordination ability of salt $\left[\mathrm{H}_{2}(\mathrm{COC})\right]\left(\mathrm{PF}_{6}\right)_{2}$ against two metal precursors $[\mathrm{M}(\mathrm{cod}) \mathrm{Cl}]_{2}$ 
(with $\mathrm{M}=\mathrm{Rh}, \mathrm{Ir}, \operatorname{cod}=1,5$-cyclooctadiene), using a synthetic method involving the in situ deprotonation of the salt in the presence of potassium hexamethyldisilazide (KHMDS) as base (Scheme 2). Aiming to obtain the corresponding cationic monometallic complexes $[\mathrm{M}(\mathrm{cod})(\mathbf{C O C})]\left(\mathrm{PF}_{6}\right)$ (with $\mathrm{M}=$ $\mathrm{Rh}, \mathrm{Ir})$, we used less than 0.5 equiv of precursor $[\mathrm{M}(\operatorname{cod}) \mathrm{Cl}]_{2}$ (with $\mathrm{M}=\mathrm{Rh}, \mathrm{Ir}$ ) with respect to ligand salt. However, we found that only trace amounts of monometallic $\mathrm{Rh}(\mathrm{I})$ complex 1a $[\mathrm{Rh}(\operatorname{cod})(\mathbf{C O C})]\left(\mathrm{PF}_{6}\right)$ were obtained (Scheme 2). Efforts to isolate its dicarbonyl derivative $\mathbf{2 a}\left[\mathrm{Rh}(\mathrm{CO})_{2}(\mathbf{C O C})\right]\left(\mathrm{PF}_{6}\right)$ after treating the crude mixture with $\mathrm{CO}(\mathrm{g})$ produced a residual amount of $\mathbf{2 a}\left[\mathrm{Rh}(\mathrm{CO})_{2}(\mathrm{COC})\right]\left(\mathrm{PF}_{6}\right)$. Recrystallization of this fraction yielded single crystals of $\mathbf{2 a}$ suitable for XRD analysis. In view of these results, we decided to explore their synthesis by varying the amount of metal precursor, from 0.5 to 1.2 equiv. We found that only cationic monometallic $\operatorname{Ir}(\mathrm{I})$ complex $\mathbf{1 b}[\operatorname{Ir}(\mathrm{I})(\mathrm{cod})(\mathrm{COC})]\left(\mathrm{PF}_{6}\right)$ could be obtained in $50 \%$ yield after 1.0 equiv of $[\operatorname{Ir}(\operatorname{cod}) \mathrm{Cl}]_{2}$ was employed, which could be easily converted into its dicarbonyl derivative $\mathbf{2 b}\left[\operatorname{Ir}(\mathrm{CO})_{2}(\mathrm{COC})\right]\left(\mathrm{PF}_{6}\right)$ in $100 \%$ after treating a solution of $\mathbf{1 b}$ in dichloromethane with $\mathrm{CO}(\mathrm{g})$. Unfortunately, the related $\mathrm{Rh}(\mathrm{I})$ 1a was not accessible following this strategy and it was obtained via transmetallation from silver (vide infra). Interestingly, we observed that when 1.2 equiv of metal precursor was employed, neutral binuclear $\mathrm{Rh}(\mathrm{I})$ complex 3a $\left[\mathrm{Rh}_{2}(\operatorname{cod})_{2} \mathrm{Cl}_{2}(\mu\right.$-COC $\left.)\right]$ was obtained in $66 \%$ yield. Conversely, the related bimetallic iridium complex $3 \mathbf{b}$ $\left[\mathrm{Ir}_{2}(\mathrm{cod})_{2} \mathrm{Cl}_{2}(\mu\right.$-COC $\left.)\right]$ could only be extracted from the crude mixture using $n$-hexane as solvent and subsequently used in the next step, without further purification. The corresponding tetracarbonyl derivatives $\mathbf{4 a}$ and $\mathbf{4 b}$ with formula $\left[\mathrm{M}_{2}(\mathrm{CO}){ }_{4} \mathrm{Cl}_{2}(\mu\right.$-COC) $]$ (with $\mathrm{M}=\mathrm{Rh}, \mathrm{Ir}$ ) were obtained in 100 and $48 \%$ yield, respectively, after bubbling $\mathrm{CO}(\mathrm{g})$ through a dichloromethane solution containing either $3 \mathbf{a}$ or $\mathbf{3 b}$. It is noteworthy to mention that complexes $3 \mathbf{a}$ and $\mathbf{4 a}$ were also accessible in similar yields (69 and 100\%, respectively) by using a methodology that entails the generation of the free biscarbene by deprotonation of the ligand salt precursor $\left[\mathrm{H}_{2}(\mathbf{C O C})\right]\left(\mathrm{PF}_{6}\right)_{2}$ with KHMDS, followed by the addition of the metal precursors $[\mathrm{Rh}(\operatorname{cod}) \mathrm{Cl}]_{2}$ or $\left[\mathrm{Rh}(\mathrm{CO})_{2} \mathrm{Cl}\right]_{2}$ in tetrahydrofuran (THF) (see Experimental Section).

Our endeavor to obtain complex 1a involved the exploration of alternative synthetic routes such as transmetallation from silver. Thus, we first reacted $\left[\mathrm{H}_{2}(\mathrm{COC})\right]\left(\mathrm{PF}_{6}\right)_{2}$ with $\mathrm{Ag}_{2} \mathrm{O}$ in the presence of $\mathrm{KCl}$ as halide source in acetonitrile, which afforded the bimetallic complex $5\left[\mathrm{Ag}_{2} \mathrm{Cl}_{2}(\mu\right.$-COC $\left.)\right]$ in $82 \%$ yield after 3 days at room temperature (RT). Then, 5 was reacted with $[\mathrm{Rh}(\operatorname{cod}) \mathrm{Cl}]_{2}$ and $\left[\mathrm{Rh}(\mathrm{CO})_{2} \mathrm{Cl}\right]$ in dichloromethane at RT to afford both complexes 1a $[\mathrm{Rh}(\mathrm{cod})$ $(\mathrm{COC})]\left(\mathrm{PF}_{6}\right)(70 \%)$ and $2 \mathrm{a}\left[\mathrm{Rh}(\mathrm{CO})_{2}(\mathrm{COC})\right]\left(\mathrm{PF}_{6}\right)(68 \%)$, respectively. Attempts to convert compound $\mathbf{1 a}$ to $\mathbf{2 a}$ by bubbling $\mathrm{CO}(\mathrm{g})$ through a dichloromethane solution of $\mathbf{1 a}$ proved to be unsuccessful.

Complexes $\mathbf{1 a}, \mathbf{1 b}, \mathbf{2 a}, \mathbf{2 b}, \mathbf{3 a}, \mathbf{4 a}$, and $\mathbf{4 b}$ were characterized spectroscopically by NMR, high-resolution mass spectrometry (HRMS), and Fourier transform infrared (FTIR) spectroscopy. The carbene carbon atom resonance for complex $\mathbf{1 a}[\mathrm{Rh}(\operatorname{cod})(\mathrm{COC})]\left(\mathrm{PF}_{6}\right)$ appears as a doublet at $169.4 \mathrm{ppm}$ $(J=41.2 \mathrm{~Hz})$, while that for $\mathbf{1 b}[\operatorname{Ir}(\operatorname{cod})(\mathrm{COC})]\left(\mathrm{PF}_{6}\right)$ appears as a singlet at $166.7 \mathrm{ppm}$ (see Figures S8 and S10, SI). The carbene carbon for the dicarbonyl complex 2a [Rh$\left.(\mathrm{CO})_{2}(\mathrm{COC})\right]\left(\mathrm{PF}_{6}\right)$ resonates at $167.6 \mathrm{ppm}(J=45.5 \mathrm{~Hz})$, similar to that of $\mathbf{2 b}\left[\operatorname{Ir}(\mathrm{CO})_{2}(\mathrm{COC})\right]\left(\mathrm{PF}_{6}\right)$, appearing as a singlet at $166.2 \mathrm{ppm}$. The carbonyl ligands for 2a display a doublet at $183.8 \mathrm{ppm}(J=56.4 \mathrm{~Hz})$, while that of $2 \mathbf{b}$ resonates as a singlet at $176.5 \mathrm{ppm}$ in the ${ }^{13} \mathrm{C}$ NMR spectra (see Figures S12 and S14, SI).

The IR spectra for both $\mathbf{2 a}$ and $\mathbf{2 b}$ display two strong bands at 2016 and $1998 \mathrm{~cm}^{-1}\left(\nu_{(\mathrm{CO}) \text { av }} 2007 \mathrm{~cm}^{-1}\right)$ in the former case and at 2065 and $1999 \mathrm{~cm}^{-1}\left(\nu_{(\mathrm{CO}) \text { av }} 2032 \mathrm{~cm}^{-1}\right)$ in the latter case, both corresponding to the two carbonyl stretching modes. The carbene carbon signal for complex $3 \mathbf{a}$ $\left[\mathrm{Rh}_{2}(\operatorname{cod})_{2} \mathrm{Cl}_{2}(\mu\right.$-COC $\left.)\right]$ is observed as a doublet at 176.1 ppm $(J=46.8 \mathrm{~Hz})$. The carbene carbon atom resonance for the bimetallic tetracarbonyl complex $4 a\left[\mathrm{Rh}_{2}(\mathrm{CO})_{4} \mathrm{Cl}_{2}(\mu\right.$ COC)] appears as a doublet at $170.0 \mathrm{ppm}(J=41.1 \mathrm{~Hz})$, similar to that of $\mathbf{4 b}\left[\operatorname{Ir}_{2}(\mathrm{CO})_{4} \mathrm{Cl}_{2}(\mu\right.$-COC $\left.)\right]$, appearing as a singlet at $170.5 \mathrm{ppm}$. The carbonyl ligands for $4 \mathrm{a}$ are observed as two doublets in the ${ }^{13} \mathrm{C}$ NMR spectrum, one at $183.4 \mathrm{ppm}$ $(J=74.6 \mathrm{~Hz})$, representing the carbonyl trans to the chlorido, and the other at $185.8 \mathrm{ppm}(J=54.5 \mathrm{~Hz})$, representing the carbonyls trans to the carbene. Similarly to $4 a$, compound $4 b$ also displays two carbonyl resonances, resonating as singlets at $168.6 \mathrm{ppm}$ (trans $\mathrm{Cl}$ ) and 181.4 (trans carbene) (see Figures S18 and S20, SI).

The IR spectra for both $\mathbf{4 a}$ and $\mathbf{4 b}$ display two strong bands at 2076 and $1995 \mathrm{~cm}^{-1}\left(\nu_{(\mathrm{CO}) \text { av }} 2035 \mathrm{~cm}^{-1}\right)$ for the former and at 2063 and $1978 \mathrm{~cm}^{-1}\left(\nu_{(\mathrm{CO}) \mathrm{av}} 2020 \mathrm{~cm}^{-1}\right)$ for the latter, which are in agreement with the values previously reported for the related complexes $\left[\mathrm{M}(\mathrm{CO})_{2} \mathrm{Cl}(\mathrm{MIC})\right]$ (with $\mathrm{M}=\mathrm{Rh}$ or $\mathrm{Ir}$; MIC $=1$ 1,2,3-triazolyilidene). ${ }^{36, c}$ The structures of $\mathbf{1} \mathbf{b}, \mathbf{2} \mathbf{a}, \mathbf{2} \mathbf{b}$, $3 a$, and $4 \mathbf{a}$ were confirmed by X-ray diffraction studies, and are shown in Figures 1-5.

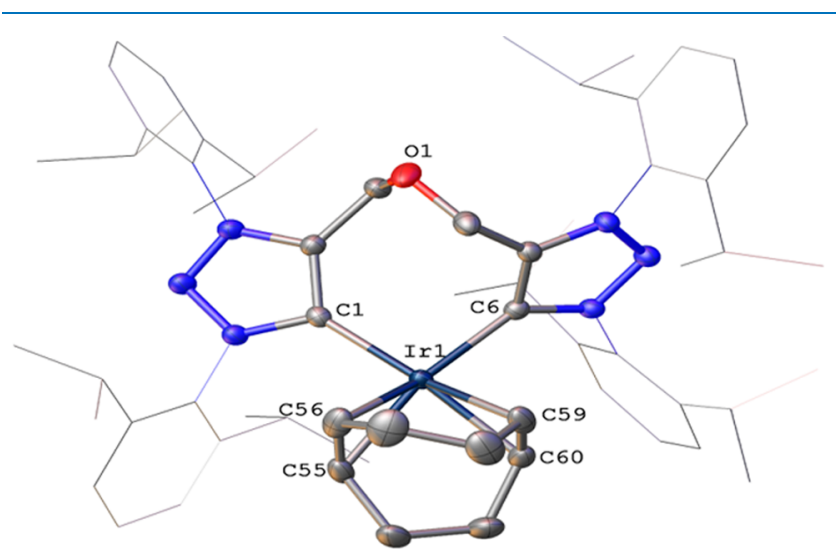

Figure 1. X-ray crystal structure of complex $1 \mathbf{b}[\operatorname{Ir}(\operatorname{cod})(\mathrm{COC})]$ $\left(\mathrm{PF}_{6}\right)$ (50\% displacement ellipsoids). [Counteranion $\left(\mathrm{PF}_{6}{ }^{-}\right)$, hydrogen atoms and solvent molecules (dichloromethane) omitted for clarity.] Selected bond distances $(\AA)$ and angles (deg): Ir1-C1 2.102(2), Ir1-C6 2.055(2), Ir1-C55 2.223(2), Ir1-C56 2.162(2), Ir1-C59 2.177(2), Ir1-C60 2.152(2), C1-Ir1-C6 92.74(8), C1Ir $1-\mathrm{C} 55 \quad 98.27(8), \quad \mathrm{C} 1-\operatorname{Ir} 1-\mathrm{C} 56 \quad 91.90(9), \quad \mathrm{C} 1-\operatorname{Ir} 1-\mathrm{C} 59$ 159.12(10), C1-Ir1-C60 163.36(10), C6-Ir1-C55 168.04(9), C6-Ir1-C56 147.91(10), C6-Ir1-C59 84.29(9), C6-Ir1-C60 $89.29(9)$.

Complex 1b $[\operatorname{Ir}(\operatorname{cod})(\mathrm{COC})]\left(\mathrm{PF}_{6}\right)$ displays a single $\operatorname{Ir}(\mathrm{I})$ metal center, which is bound to two 1,2,3-triazol-5-ylidene ligands, and a 1,5-cyclooctadiene (cod). The $\mathrm{Ir}-\mathrm{C}_{\text {carbene }}$ bond distances are 2.102(2) and 2.055(2) Å, respectively.

The bond angle between the two carbenic carbons and the iridium center was found to be $92.7(8)^{\circ}$, which confirms the pseudo-square planar geometry of the $\operatorname{Ir}(\mathrm{I})$ center. Complex 


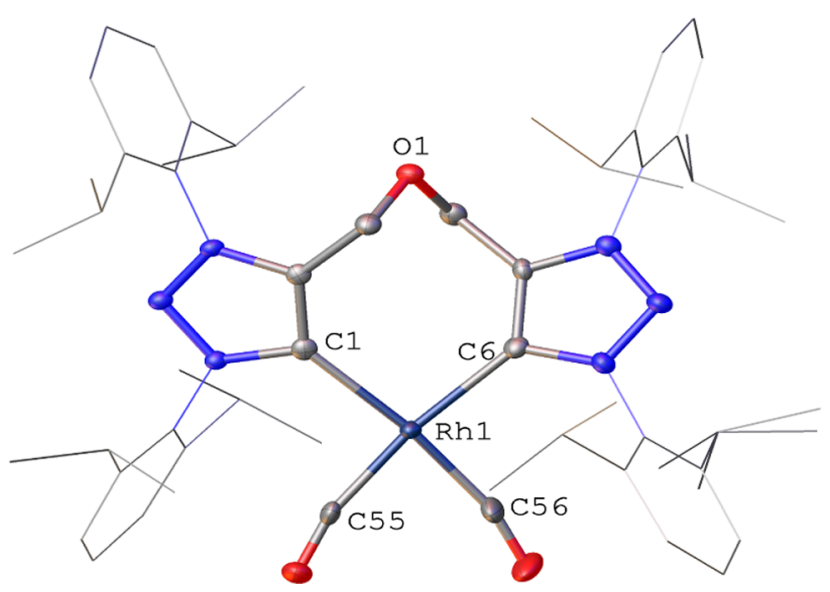

Figure 2. X-ray crystal structure of complex 2a $\left[\mathrm{Rh}(\mathrm{CO})_{2}(\mathrm{COC})\right]$ $\left(\mathrm{PF}_{6}\right)$ (50\% displacement ellipsoids). [Counteranion $\left(\mathrm{PF}_{6}{ }^{-}\right)$and hydrogen atoms omitted for clarity.] Selected bond distances $(\AA)$ and angles (deg): Rh1-C1 2.122(4), Rh1-C6 2.110(4), Rh1-C55 1.878(4), Rh1-C56 1.878(4), C1-Rh1-C6 95.24(14), C1-Rh1C55 93.09(15), C1-Rh1-C56 167.67(17), C6-Rh1-C55 167.76(15), C6-Rh1-C56 90.90(16).

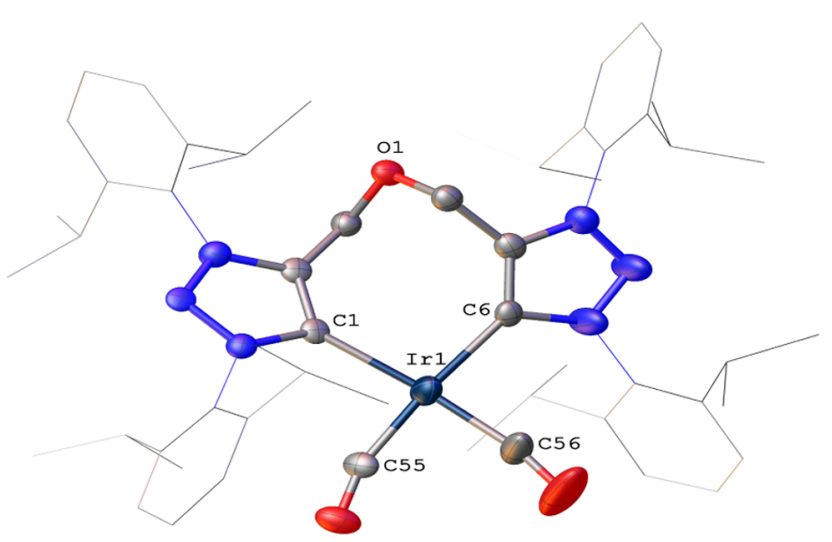

Figure 3. X-ray crystal structure of complex $\mathbf{2 b}\left[\operatorname{Ir}(\mathrm{CO})_{2}(\mathrm{COC})\right]$ $\left(\mathrm{PF}_{6}\right)$ (50\% displacement ellipsoids). [Counteranion $\left(\mathrm{PF}_{6}{ }^{-}\right)$and hydrogen atoms omitted for clarity.] Selected bond distances $(\AA)$ and angles (deg): Ir1-C1 2.110(16), Ir1-C6 2.059(15), Ir1-C55 1.824(17), Ir1-C56 1.868(19), C1-Ir1-C6 93.7(6), C1-Ir1-C55 91.5(7), C1-Ir1-C56 169.2(8), C6-Ir1-C55 172.6(7), C6-Ir1C56 92.7(7).

2a, $\left[\mathrm{Rh}(\mathrm{CO})_{2}(\mathrm{COC})\right]\left(\mathrm{PF}_{6}\right)$, displays a single $\mathrm{Rh}(\mathrm{I})$ metal center in a slightly distorted square planar geometry bound to two 1,2,3-triazol-5-ylidene ligands, and two carbonyls groups. The $\mathrm{Rh}-\mathrm{C}_{\text {carbene }}$ bond distances are 2.122(4) and 2.110(4) $\AA$, respectively. The bond angle between the two carbenic carbons and the rhodium center was found to be $93.09(15)^{\circ}$, which confirms the pseudo-square planar geometry of the $\mathrm{Rh}(\mathrm{I})$ center.

Complex $2 \mathbf{b}\left[\operatorname{Ir}(\mathrm{CO})_{2}(\mathrm{COC})\right]\left(\mathrm{PF}_{6}\right)$ shows a single $\operatorname{Ir}(\mathrm{I})$ metal center in a slightly distorted square planar geometry, which are coordinated to two 1,2,3-triazol-5-ylidene moieties, and two carbonyls. The $\mathrm{Ir}-\mathrm{C}_{\text {carbene }}$ bond distances are 2.110(16) and 2.059(15) $\AA$, respectively. The bond angle of $93.7(6)^{\circ}$ between the two carbenic carbons and the iridium center confirms the pseudo-square planar geometry of the $\operatorname{Ir}(\mathrm{I})$ center.

The molecular structure of complex $3 \mathbf{a}\left[\mathrm{Rh}_{2}(\operatorname{cod}){ }_{2} \mathrm{Cl}_{2}(\mu\right.$ COC)] (Figure 4) shows two $\mathrm{Rh}(\mathrm{I})$ centers, each bound to a

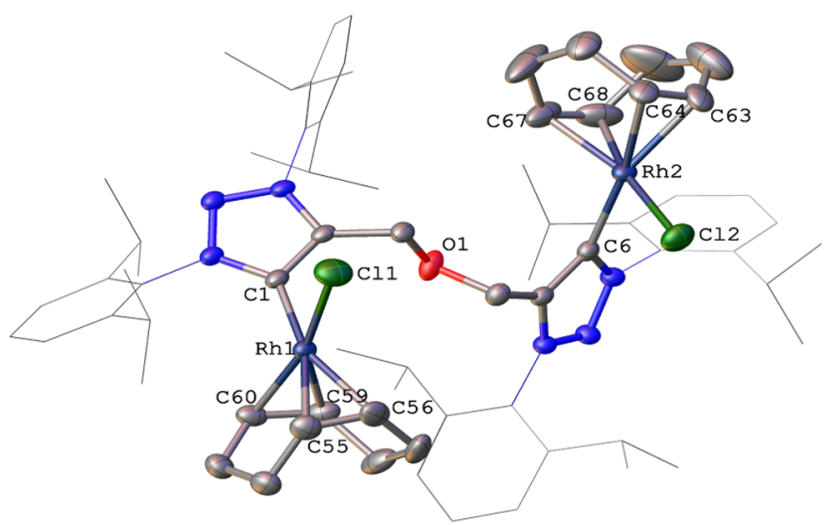

Figure 4. X-ray crystal structure of complex $3 \mathbf{a}\left[\mathrm{Rh}_{2}(\operatorname{cod})_{2} \mathrm{Cl}_{2}(\mu\right.$ COC)] (50\% displacement ellipsoids). (Hydrogen atoms and solvent molecules (dichloromethane) omitted for clarity.) Selected bond distances (A) and angles (deg): Rh1-C1 2.030(2), Rh1-Cl1 2.3927(7), Rh1-C55 2.197(3), Rh1-C56 2.177(3), Rh1-C59 2.099(3), Rh1-C60 2.089(2), Rh2-C6 2.043(2), Rh2-Cl2 2.3741(7), Rh2-C63 2.167(3), Rh2-C64 2.205(2), Rh2-C67 2.087(3), C1-Rh1-Cl1 86.46(7), C55-Rh1-C1 165.77(10), C56-Rh1-C1 157.78(10), C59-Rh1-C1 94.40(10), C60-Rh1C1 93.06(9), C6-Rh2-Cl2 87.31(7), C6-Rh2-C63 155.92(11), C6-Rh2-C64 167.10(10), C6-Rh2-C67 95.81(10), C6-Rh2C68 93.60(11).

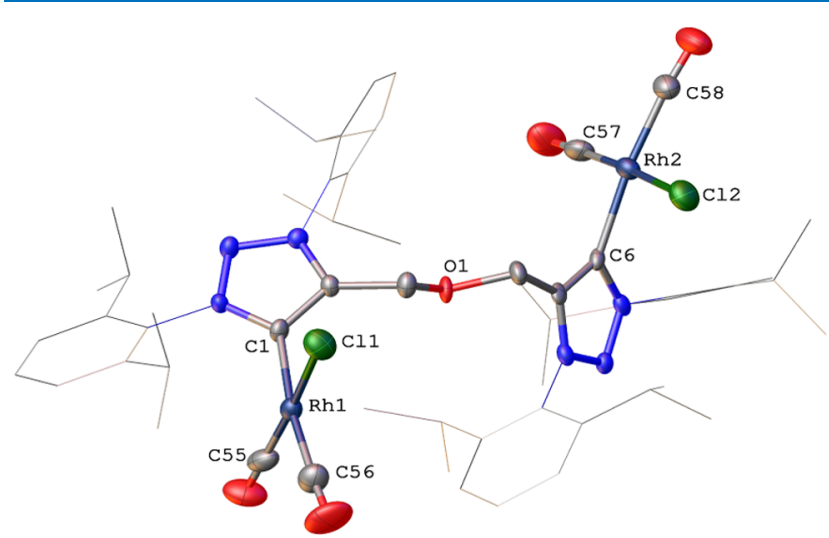

Figure 5. X-ray crystal structure of complex $4 \mathbf{a}\left[\mathrm{Rh}_{2}(\mathrm{CO})_{4} \mathrm{Cl}_{2}(\mu\right.$ COC)] (50\% displacement ellipsoids). (Hydrogen atoms omitted for clarity.) Selected bond distances ( $\AA$ ) and angles (deg): Rh1-C1 2.054(5), Rh1-Cl1 2.3434(16), Rh1-C55 1.831(7), Rh1-C56 1.899(7), Rh2-C6 2.041(5), Rh2-Cl2 2.3672(17), Rh2-C57 1.812(7), Rh2-C58 1.905(6), C1-Rh1-Cl1 87.50(15), C55Rh1-C1 93.1(2), C56-Rh1-C1 172.9(2), C6-Rh2-Cl2 85.70(15), C6-Rh2-C57 91.6(2), C6-Rh2-C58 174.0(2).

1,2,3-triazol-5-ylidene, a 1,5-cyclooctadiene (cod), and a chlorido ligand. The $\mathrm{Rh}-\mathrm{C}_{\text {carbene }}$ bond distances are 2.043(2) and 2.030(2) $\AA$, respectively. Interestingly, the metal centers and the (cod) ligands are facing in opposite directions (isomer DL) probably due to steric constraints imparted by the bulky ligand substituents. Related examples in the literature of bis-NHC $\mathrm{Rh}(\mathrm{I})$ complexes linked by an aliphatic chain indicate the possibility of forming different isomers meso and DL. ${ }^{10}$ In our case, we only observed one set of NMR resonances confirming the presence of only one of the isomers. In complex $\mathbf{4 a}\left[\mathrm{Rh}_{2}(\mathrm{CO})_{4} \mathrm{Cl}_{2}(\mu\right.$-COC) (Figure 5), two $\mathrm{Rh}(\mathrm{I})$ centers are present, each one is bound to a 1,2,3triazol-5-ylidene ligand, two carbonyls, and a chlorido. The 
Scheme 3. Synthesis of Metal Complexes 6-9

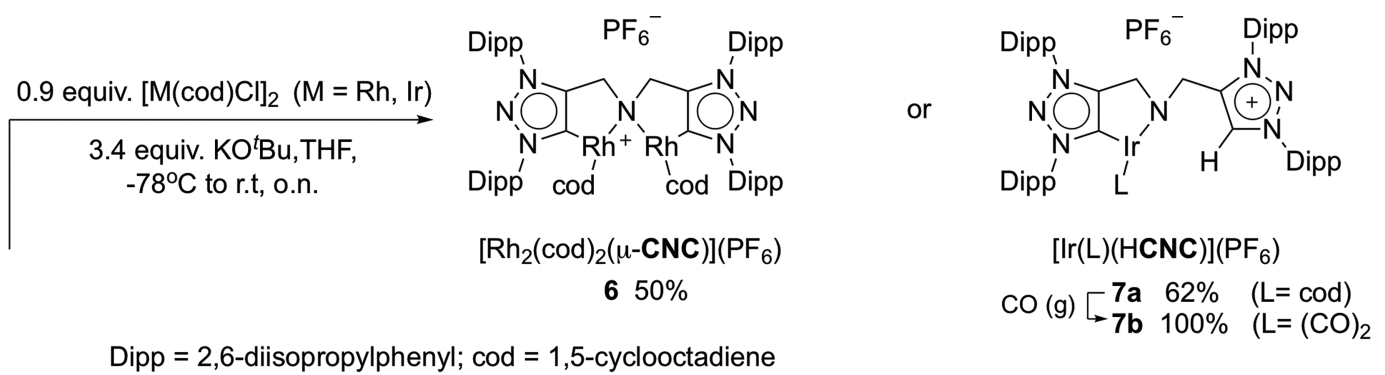

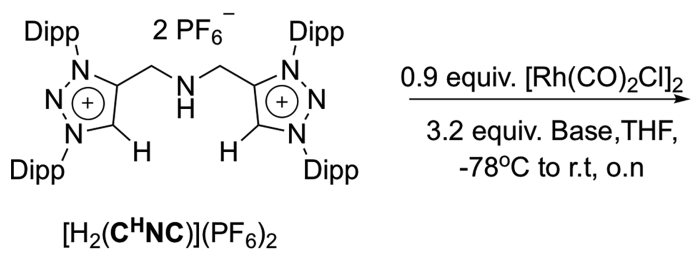

$$
\begin{array}{cr}
\text { Base }=\underset{\mathrm{KHMDS}}{\mathrm{KH}} \quad \mathbf{8 a} 70 \% \\
77 \%
\end{array}
$$

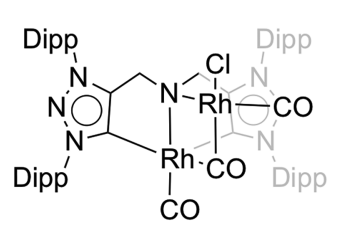

$\left[\mathrm{Rh}_{2}(\mathrm{CO})_{3} \mathrm{Cl}(\mu-\mathrm{CNC})\right]$

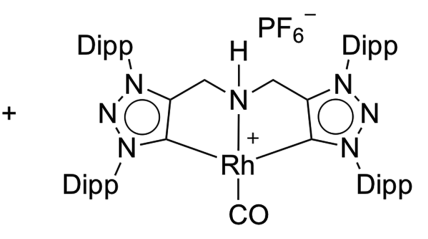

$\left[\mathrm{Rh}(\mathrm{CO})\left(\mathbf{C}^{\mathrm{H}} \mathrm{NC}\right)\right]\left(\mathrm{PF}_{6}\right)$

8b $30 \%$ $0 \%$

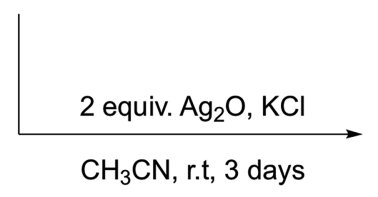<smiles></smiles>

0.9 equiv. $\left[\mathrm{Rh}(\mathrm{CO})_{2} \mathrm{Cl}_{2}, \mathrm{KPF}_{6}\right.$

8b, $\left[\mathrm{Rh}(\mathrm{CO})\left(\mathrm{C}^{\mathrm{H}} \mathrm{NC}\right)\right]\left(\mathrm{PF}_{6}\right), 88 \%$

DCM, r.t, o.n

$\left[\mathrm{Ag}_{2} \mathrm{Cl}_{2}\left(\mu-\mathrm{C}^{\mathrm{H}} \mathrm{NC}\right)\right]$

$985 \%$

$\mathrm{Rh}-\mathrm{C}_{\text {carbene }}$ bond distances are 2.054(5) and 2.041(5) $\AA$, respectively.

Based on the reactivity observed for the ligand salt $\left[\mathrm{H}_{2}(\mathbf{C O C})\right]\left(\mathrm{PF}_{6}\right)_{2}$, we decided to explore the coordination versatility of the ligand precursor $\left[\mathrm{H}_{2}\left(\mathrm{C}^{\mathrm{H}} \mathbf{N C}\right)\right]\left(\mathrm{PF}_{6}\right)_{2}$ toward two different $\mathrm{Rh}(\mathrm{I})$ metal precursors, $[\mathrm{Rh}(\operatorname{cod}) \mathrm{Cl}]_{2}$ and $\left[\mathrm{Rh}(\mathrm{CO})_{2} \mathrm{Cl}\right]_{2}$, and also an $\operatorname{Ir}(\mathrm{I})$ metal precursor, $[\operatorname{Ir}(\operatorname{cod})$ $\mathrm{Cl}]_{2}$, with the ultimate goal of obtaining a pincer complex analogous to the CNC-bis(triazolylidene) pincer ligand based on a rigid carbazole scaffold. ${ }^{6 j}$ In this case, when $\mathrm{KO}^{t} \mathrm{Bu}$ was used as base in the presence of $[\mathrm{Rh}(\operatorname{cod}) \mathrm{Cl}]_{2}$, complex 6 $\left[\mathrm{Rh}_{2}(\mathrm{cod})_{2}(\mu\right.$-CNC) $]\left(\mathrm{PF}_{6}\right)$ (Scheme 3 ) was obtained in $50 \%$ yield as the only product of the reaction. Conversely, when $[\mathrm{Ir}(\operatorname{cod}) \mathrm{Cl}]_{2}$ dimer was used as metal precursor and $\mathrm{KO}^{t} \mathrm{Bu}$ as base, cationic monometallic $\operatorname{Ir}(\mathrm{I})$ complex $7 \mathbf{a}[\operatorname{Ir}(\mathrm{cod})$ (HCNC) $]\left(\mathrm{PF}_{6}\right)$ (Scheme 3) was obtained in $62 \%$ yield. The carbene carbon atom resonance for complex $7 \mathbf{a}$ appears at $166.5 \mathrm{ppm}$. The related dicarbonylated derivative $7 \mathbf{b}$ [Ir$\left.(\mathrm{CO})_{2}(\mathrm{HCNC})\right]\left(\mathrm{PF}_{6}\right)$ could be easily obtained in $100 \%$ yield after bubbling $\mathrm{CO}(\mathrm{g})$ through a dichloromethane solution containing $7 \mathrm{a}$. The carbene carbon atom resonance for the dicarbonyl complex $7 \mathbf{b}$ appears at $174.1 \mathrm{ppm}$, while the carbonyl ligands give rise to two signals at 186.5 and 178.8 $\mathrm{ppm}$. The IR spectrum displayed two strong bands at 2035 and $1964 \mathrm{~cm}^{-1}\left(\nu(\mathrm{co})_{\mathrm{av}}=1999.5 \mathrm{~cm}^{-1}\right)$ corresponding to the two carbonyl stretching modes. These bands occur at frequencies significantly higher than the $2032.5 \mathrm{~cm}^{-1}$ observed for the cationic $\mathbf{2 b}$ and related examples in the literature, reflecting the donating character of the amido group. ${ }^{11,18}$ In these two complexes, the metal is bonded to only two of the three possible coordinating sites of the $\mathrm{CNC}$ ligand $\left[\mathrm{H}_{2}\left(\mathrm{C}^{\mathrm{H}} \mathrm{NC}\right)\right]$ -
$\left(\mathrm{PF}_{6}\right)_{2}$ featuring a pendant triazolium salt. All our attempts using KHMDS as base resulted in the formation of untreatable mixtures; similarly, attempts at a subsequent deprotonation and metalation step after isolation of $7 \mathbf{a} / \mathbf{b}$ did not proceed smoothly.

These observations reflect the marked differences in reactivity and coordination modes for ligand precursor $\left[\mathrm{H}_{2}\left(\mathrm{C}^{\mathrm{H}} \mathrm{NC}\right)\right]\left(\mathrm{PF}_{6}\right)_{2}$ with a $\mathrm{N}-\mathrm{H}$ bridge, compared to $\left[\mathrm{H}_{2}(\mathrm{COC})\right]\left(\mathrm{PF}_{6}\right)_{2}$ with the ether bridge, even though the ligand scaffolds share the same linker length. MIC-anchored/ pendant-triazolium species are not accessible via transmetallation reactions and isolation often occurs serendipitously and is hard to predict. In contrast to their NHCs analogues, only two examples are known. ${ }^{12}$ Such examples are however useful for the preparation of homo- and heterobimetallic complexes. In addition, the availability of $\operatorname{Ir}(\mathrm{I})$ complexes bearing an $\mathrm{N}$-donor-functionalized 1,2,3-triazolylidene ligands is very appealing for comparative reasons, since the related $\mathrm{Rh}(\mathrm{I})$ derivatives have recently shown hemilability and cooperativity in alkyne hydrothiolation reactions. ${ }^{16}$

When $\left[\mathrm{Rh}(\mathrm{CO})_{2} \mathrm{Cl}\right]_{2}$ was employed as metal precursor in combination with KHMDS as base, an inseparable mixture of complexes 8a $\left[\mathrm{Rh}_{2}(\mathrm{CO})_{3} \mathrm{Cl}(\mu\right.$-CNC $\left.)\right]$ and $\mathbf{8 b}[\mathrm{Rh}(\mathrm{CO})$ $\left.\left(\mathbf{C}^{\mathrm{H}} \mathbf{N C}\right)\right]\left(\mathrm{PF}_{6}\right)$ in a $70 / 30 \%$ ratio (Scheme 3$)$, where complex $8 \mathbf{a}$ is the major product (see Figures S31 and S32, SI) was obtained. Conversely, when $\mathrm{KO}^{t} \mathrm{Bu}$ was used instead, the reaction produces selectively the bimetallic $8 \mathbf{a}\left[\mathrm{Rh}_{2}(\mathrm{CO})_{3} \mathrm{Cl}\right.$ $(\mu$-CNC $)]$ in $77 \%$ yield as the only product. The potential noninnocent/hemilabile implication of the monometallic complex $\mathbf{8 b}\left[\mathrm{Rh}(\mathrm{CO})\left(\mathbf{C}^{\mathrm{H}} \mathbf{N C}\right)\right]\left(\mathrm{PF}_{6}\right)$ in catalysis piqued our interest in the isolation of this complex featuring the $\mathrm{CNC}$ 
ligand coordinated in a pincer manner. Thus, we decided to attempt an alternative preparatory route, namely, the transmetallation from silver. ${ }^{3 \mathrm{~b}, 9,13}$ Treatment of $\left[\mathrm{H}_{2}\left(\mathbf{C}^{\mathrm{H}} \mathbf{N C}\right)\right]$ $\left(\mathrm{PF}_{6}\right)_{2}$ with $\mathrm{Ag}_{2} \mathrm{O}$ in the presence of $\mathrm{KCl}$ as halide source in acetonitrile afforded the bimetallic complex $9\left[\mathrm{Ag}_{2} \mathrm{Cl}_{2}(\mu\right.$ $\left.\left.\mathrm{C}^{\mathrm{H}} \mathrm{NC}\right)\right]$ in $85 \%$ yield after 3 days at room temperature. ${ }^{9 \mathrm{e}}$ Next, 9 was reacted with $\left[\mathrm{Rh}(\mathrm{CO})_{2} \mathrm{Cl}\right]_{2}$ in dichloromethane at room temperature to afford the desired cationic monometallic complex $\mathbf{8 b}\left[\mathrm{Rh}(\mathrm{CO})\left(\mathrm{C}^{\mathrm{H}} \mathrm{NC}\right)\right]\left(\mathrm{PF}_{6}\right)$ in $88 \%$ yield as the only product (Scheme 3 ). The ${ }^{1} \mathrm{H}$ NMR spectrum of the cationic complex displays resonance of the $\mathrm{N}-\mathrm{H}$ group at $6.51 \mathrm{ppm}$. In the ${ }^{13} \mathrm{C}$ NMR spectrum, the $\mathrm{C}_{\text {carbene }}$ atom resonates as a doublet at $178.7 \mathrm{ppm}(J=44.2 \mathrm{~Hz})$, while the carbonyl ligand trans to the $\mathrm{N}-\mathrm{H}$ group resonates as a doublet at $192.3 \mathrm{ppm}(J$ $=81.5 \mathrm{~Hz}$ ). Also in the IR spectrum, the $\nu_{\mathrm{NH}}$ and $\nu_{\mathrm{CO}}$ bands are observed at 3256 and $1974 \mathrm{~cm}^{-1}$, respectively (see Experimental Section, and Figures S33 and S34, SI). Despite all our efforts, single crystals of $\mathbf{8 b}$, suitable for X-ray analysis, could not be obtained. Attempts to extend this methodology for the preparation of the $\operatorname{Ir}(\mathrm{I})$ analogue $\left[\operatorname{Ir}(\mathrm{CO})\left(\mathbf{C}^{\mathrm{H}} \mathbf{N C}\right)\right]$ $\left(\mathrm{PF}_{6}\right)$ employing several metal precursors such as $[\operatorname{Ir}(\operatorname{cod}) \mathrm{Cl}]_{2}$, $[\operatorname{Ir}(\mu \text {-OMe })(\operatorname{cod})]_{2}, \quad\left[\operatorname{Ir}(\text { coe })_{2} \mathrm{Cl}\right]_{2}$, or $\operatorname{Ir}(\mathrm{CO})_{2}($ acac $)$ were unsuccessful. The difficulty in isolating the iridium complexes might be due to the difference in the stability of the metalcarbon bonds for iridium compared to rhodium, or due to the larger size of the metal center along with the steric hindrance imposed by the bulky wingtips of the 1,2,3-triazolylidene ligands. Complexes 6, 7a, 7b, 8a, 8b, and 9 were spectroscopically characterized by NMR, HRMS, and FTIR analyses. The molecular structures of complexes $\mathbf{6}, \mathbf{7 b}$, and $8 \mathbf{a}$ were confirmed by X-ray diffraction studies, and are shown in Figures 6-8, respectively.

The structure of the cationic complex $6\left[\mathrm{Rh}_{2}(\operatorname{cod})_{2}(\mathrm{CNC})\right]-$ $\left(\mathrm{PF}_{6}\right)$ comprises two $\mathrm{Rh}(\mathrm{I})$ atoms, each one bound to a 1,2,3triazolylidene ligand and a 1,5-cyclooctadiene (cod). The two metal centers are bridged by the amido functionality with a

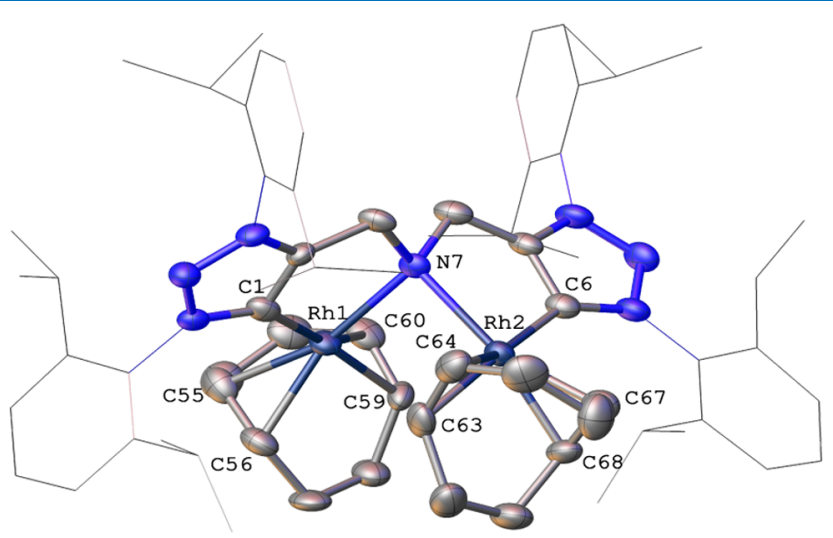

Figure 6. X-ray crystal structure of complex $6\left[\mathrm{Rh}_{2}(\operatorname{cod})_{2}(\mu\right.$ $\mathrm{CNC})]\left(\mathrm{PF}_{6}\right)$ (50\% displacement ellipsoids). [Counteranion $\left(\mathrm{PF}_{6}^{-}\right)$, hydrogen atoms, and solvent molecules (dichloromethane) omitted for clarity.]. Selected bond distances $(\AA)$ and angles (deg): Rh1-Rh2 3.1963(12), Rh1-C1 2.035(11), Rh2-C6 2.037(10), Rh1-N7 2.209(8), Rh2-N7 2.217(8), Rh1-C55 2.125(12), Rh1-C56 2.136(11), Rh1-C59 2.223(11), Rh1-C60 2.191(11), Rh2-C63 2.207(11), Rh2-C64 2.179(12), Rh1-N7-Rh2 92.5(3), C1-Rh1N7 80.8(4), C1-Rh1-C55 93.9(4), C1-Rh1-C56 94.7(4), C1Rh1-C59 169.6(4), C1-Rh1-C60 153.9(4), C6-Rh2-C63 167.9(4), C6-Rh2-C64 156.4(4), C6-Rh2-C67 95.4(5), C6Rh2-C68 95.3(4).

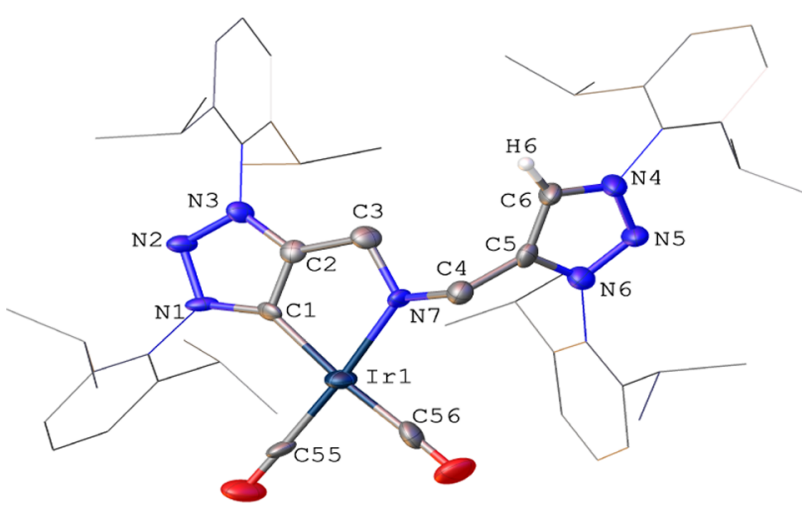

Figure 7. X-ray crystal structure of complex $7 \mathbf{b}\left[\operatorname{Ir}(\mathrm{CO})_{2}(\mathrm{HCNC})\right]$ $\left(\mathrm{PF}_{6}\right)$ (50\% displacement ellipsoids). (Hydrogen atoms, counteranion $\left(\mathrm{PF}_{6}^{-}\right)$, and solvent molecules (dichloromethane) omitted for clarity.) Selected bond distances ( $\AA$ ) and angles (deg): Ir1-C1 2.032(9), Ir1-N7 2.048(7), Ir1-C55 1.865(9), Ir1-C56 1.866(11), C1-Ir1-N7 78.0(3), C1-Ir1-C55 97.2(3), C1-Ir1-C56 174.3(4), N7-Ir1-C55 175.3(3), N7-Ir1-C56 96.3(3).

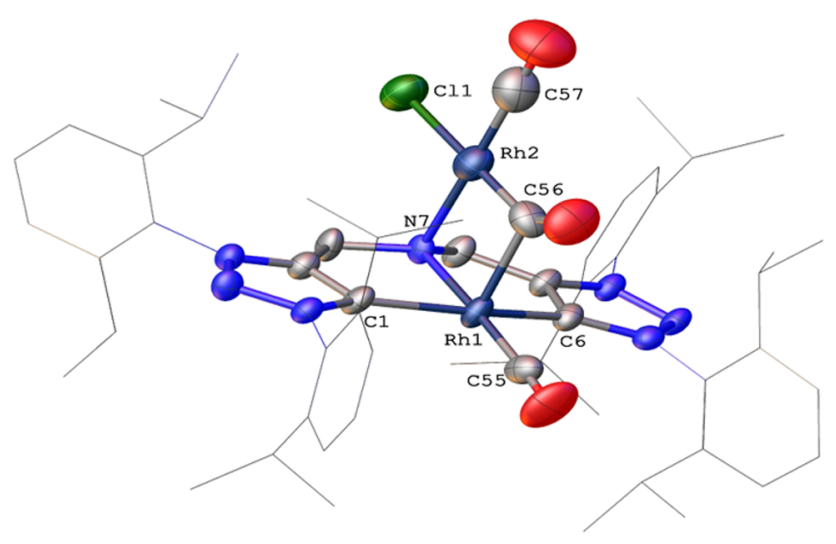

Figure 8. X-ray crystal structure of complex 8a $\left[\mathrm{Rh}_{2}(\mathrm{CO})_{3} \mathrm{Cl}(\mu\right.$ CNC)] (50\% displacement ellipsoids). [Hydrogen atoms omitted for clarity.] Selected bond distances ( $\AA$ ) and angles (deg): Rh1-Rh2 2.9698(12), Rh1-C1 2.046(8), Rh1-C6 2.029(8), Rh1-N7 2.113(6), Rh1-C55 51.846(10), Rh1-C56 2.211(10), Rh2-N7 2.189(7), Rh2-C56 1.909(11), Rh2-C57 1.819(15), Rh2-Cl1 2.385(3), C1-Rh1-C6 157.3(3), C1-Rh1-N7 79.3(3), C1-Rh1C55 100.0(3), N7-Rh1-C56 87.3(3), Rh1-N7-Rh2 56 47.41(18), N7-Rh2-C57 177.7(4).

short $\mathrm{Rh}-\mathrm{Rh}$ distance of $3.196 \AA$, slightly shorter than the $3.226 \AA$ observed for a related bimetallic $\mathrm{Rh}(\mathrm{I})$ complex described by Bertrand and co-workers, which features an anionic 1,2,3-triazolylidene ligand example. ${ }^{15}$ The structure of the cationic monometallic $\operatorname{Ir}(\mathrm{I})$ complex $7 \mathbf{b}$ [Ir$\left.(\mathrm{CO})_{2}(\mathrm{HCNC})\right]\left(\mathrm{PF}_{6}\right)$, featuring a pendant triazolium salt, displays a pseudo-square planar geometry around the $\operatorname{Ir}(\mathrm{I})$ center (Figure 7). The metal is bonded to one 1,2,3triazolylidene ligand, the bridging nitrogen acting as a oneelectron donor, and two carbonyls completing the 16VE coordination sphere. The $\mathrm{Ir}-\mathrm{C}$ and $\mathrm{Ir}-\mathrm{N}$ bond distances of

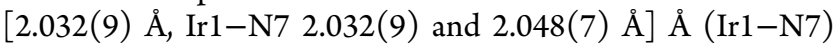
are within the expected range. The structure of the binuclear complex $8 \mathrm{a}\left[\mathrm{Rh}_{2}(\mathrm{CO})_{3} \mathrm{Cl}(\mathrm{CNC})\right]$ consists of two $\mathrm{Rh}(\mathrm{I})$ atoms bridged by the $\mathrm{N}$ atom of the CNC ligand and a carbonyl group. The $\mathrm{Rh}-\mathrm{Rh}$ distance $(2.9698 \AA$ ) between the two metal centers of $\mathbf{8 a}$ is within the range for related amidobridged rhodium complexes. ${ }^{15}$ 
The first rhodium atom shows a slightly distorted square planar geometry featuring a pincer ligand with a central amidoligating atom and the two 1,2,3-triazol-5-ylidene ligand units. A carbonyl ligand completes the coordination sphere around the metal center. The second rhodium atom displays a square planar geometry bound to the nitrogen atom of the CNC ligand, two carbonyls, and a chloride. In solution, however, there is no evidence for the presence of a bridging carbonyl ligand between the two rhodium metal centers.

Both the ${ }^{13} \mathrm{C}$ NMR and FTIR spectra are consistent with the presence of three terminal $\mathrm{CO}$ ligands. In the ${ }^{13} \mathrm{C}$ NMR spectrum, the $\mathrm{C}_{\text {carbene }}$ atom resonates as a doublet at 173.7 ppm $(J=44.5 \mathrm{~Hz})$, while the carbonyl ligand trans to the chlorido resonates as a doublet at $187.4 \mathrm{ppm}(J=75.7 \mathrm{~Hz})$. The two CO ligands, both trans to ligand-N, are observed at $193.7 \mathrm{ppm}(J=71.7 \mathrm{~Hz})$. Also in the IR spectrum, only two bands are observed at 2019 and $1981 \mathrm{~cm}^{-1}$.

What is especially noteworthy is the different bonding modes displayed by the coordinated $\left[\mathrm{H}_{2}\left(\mathbf{C}^{\mathrm{H}} \mathbf{N C}\right)\right]\left(\mathrm{PF}_{6}\right)_{2}$ for complexes 6-8, with either a trivalent or a tetravalent central nitrogen atom. In the case of symmetric $6\left[\mathrm{Rh}_{2}(\operatorname{cod})_{2}(\mu\right.$ $\mathrm{CNC})]\left(\mathrm{PF}_{6}\right)$, the positive charge is presumably located on the ammonium-type $\mathrm{N}$-atom, acting as a one electron donor to each of the $\mathrm{Rh}$ metal centers. ${ }^{14}$ In contrast, 8a $\left[\mathrm{Rh}_{2}(\mathrm{CO})_{3} \mathrm{Cl}-\right.$ $(\mu$-CNC)] also displays a tetravalent $\mathrm{N}$-atom, but in this case, the bonding can be better described as a neutral amino ligand that binds via a one electron donation to the bis(triazolylidene $)(\mathrm{CO})_{2}-\mathrm{Rh}$ metal and a lone pair donation to the $\mathrm{Rh}(\mathrm{CO})_{2} \mathrm{Cl}$ fragment. In $\mathbf{8 b}\left[\mathrm{Rh}(\mathrm{CO})\left(\mathrm{C}^{\mathrm{H}} \mathrm{NC}\right)\right]\left(\mathrm{PF}_{6}\right)$, the protonated nitrogen atom acts exclusively as a neutral twoelectron donor, while in the case of $7 \mathbf{a} / 7 \mathbf{b}$, the trivalent nitrogen exhibits anionic bonding (one electron donor) to iridium. Finally, absence of base in the reaction of $\left[\mathrm{H}_{2}\left(\mathrm{C}^{\mathrm{H}} \mathrm{NC}\right)\right]\left(\mathrm{PF}_{6}\right)_{2}$ with $\mathrm{Ag}_{2} \mathrm{O}$ provides access to a bimetallic metal complex $9\left[\mathrm{Ag}_{2} \mathrm{Cl}_{2}(\mu\right.$-CNC $\left.)\right]$, where the nitrogen is not coordinated.

\section{CONCLUSIONS}

In summary, we have reported the synthesis of both ether- and amine-linked bis(1,2,3-triazolylidene) ligand salt precursors via a 1,3-dipolar cycloaddition between 1,3-bis-(2,6diisopropylphenyl)triaz-1-ene and the corresponding bisalkyne. We have studied their coordination versatility preferentially by reacting the in situ deprotonated salt precursor with either KHMDS or ${ }^{t} \mathrm{BuOK}$ as a base, and with $\mathrm{Rh}(\mathrm{I})$ or $\operatorname{Ir}(\mathrm{I})$ metal precursors. Both COC- and CNC-bis(1,2,3-triazol-5ylidene) ligands displayed very different reactivities and coordination modes, which are strongly influenced by the base employed. Exceptionally, when the desired monometallic complexes could not be accessible via in situ deprotonation, the transmetallation route from silver was employed instead. We found that the COC ligand can act as either a chelating ligand or a bridging ligand, yielding either mono- or bimetallic $\mathrm{Rh}(\mathrm{I})$ and $\operatorname{Ir}(\mathrm{I})$ complexes showing no preference between the metals. In contrast, the $\mathrm{CNC}$ ligand revealed a coordination inclination toward rhodium complexes. Two unusual bimetallic $\mathrm{Rh}(\mathrm{I})$ complexes where the metal centers are bridged by the central amido functionality of the anionic CNC ligand, along with a cationic monometallic $\mathrm{Rh}(\mathrm{I})$ complex bearing a neutral CNC bis(1,2,3-triazol-5-ylidene)-based pincer ligand, were obtained. However, only a monometallic $\operatorname{Ir}(\mathrm{I})$ complex with a pendant uncoordinated triazolium arm could be isolated. The catalytic performances of the mono- and bimetallic complexes are currently under investigation in our laboratories.

\section{EXPERIMENTAL SECTION}

General Experimental Procedures. All synthetic manipulations, unless otherwise stated, were performed under a $\mathrm{N}_{2}(\mathrm{~g})$ or $\operatorname{Ar}(\mathrm{g})$ atmosphere using standard Schlenk line techniques. Air-sensitive solids were stored and handled in an InertLab glovebox. Preparation of NMR and crystallization samples that also require an inert atmosphere were performed in a glovebox.

The following ligand and metal precursors were synthesized in this study according to known synthetic procedures: 1,3-bis(2,6-diisopropylphenyl)triaz-1-ene, ${ }^{16}$ sodium hypochlorite, ${ }^{17}$ $N$-(tert-butyloxy)carbonyl dipropargylamine, ${ }^{18}$ di- $\mu$-chloro-bis(1,5-cyclooctadiene)dirhodium(I), ${ }^{19}$ di- $\mu$-chloro-bis $(1,5$ cyclooctadiene)dirhodium(I), ${ }^{20}$ and di- $\mu$-chloro-bis $(1,5$ cyclooctadiene)diiridium(I). ${ }^{21}$ All other reagents were obtained from commercial sources and were used without any further purification.

Unless otherwise stated, only anhydrous solvents were used for the experimental procedures. Anhydrous tetrahydrofuran (THF) and diethyl ether (DEE) were obtained after distillation over sodium wire $\mathrm{Na}(\mathrm{s})$ and benzophenone under a $\mathrm{N}_{2}$ atmosphere. Anhydrous toluene and hexane were obtained after distillation over sodium wire under $\mathrm{N}_{2}$ atmosphere. Anhydrous dichloromethane was obtained after distillation over calcium hydride $\left(\mathrm{CaH}_{2}\right)$ under $\mathrm{N}_{2}$ atmosphere. Deuterated benzene was dried over sodium and distilled under Ar atmosphere. Deuterated acetonitrile, chloroform, and dichloromethane were dried over calcium hydride under $\operatorname{Ar}(\mathrm{g})$ atmosphere.

Nuclear magnetic resonance (NMR) spectra were obtained using a Bruker AVANCE-III-300 operating at $300.13 \mathrm{MHz}$ for ${ }^{1} \mathrm{H}, 75.47 \mathrm{MHz}$ for ${ }^{13} \mathrm{C}, 121.49 \mathrm{MHz}$ for ${ }^{31} \mathrm{P}$, and $282.40 \mathrm{MHz}$ for ${ }^{19} \mathrm{~F}$; AVANCE-III-400 operating at $400.21 \mathrm{MHz}$ for ${ }^{1} \mathrm{H}$, 100.64 MHz for ${ }^{13} \mathrm{C}, 162.01 \mathrm{MHz}$ for ${ }^{31} \mathrm{P}$, and $376.57 \mathrm{MHz}$ for ${ }^{19} \mathrm{~F}$; or AVANCE-III-500 operating at $500.13 \mathrm{MHz}$ for ${ }^{1} \mathrm{H}$, 125.31 MHz for ${ }^{13} \mathrm{C}, 202.46 \mathrm{MHz}$ for ${ }^{31} \mathrm{P}$, and $470.59 \mathrm{MHz}$ for ${ }^{19} \mathrm{~F} .{ }^{1} \mathrm{H}$ Chemical shifts are reported as $\delta(\mathrm{ppm})$ values downfield from $\mathrm{Me}_{4} \mathrm{Si}$, and chemical shifts were referenced to residual nondeuterated solvent peaks $\left(\mathrm{CDCl}_{3}: 7.260 \mathrm{ppm}\right.$, $\mathrm{C}_{6} \mathrm{D}_{6}: 7.160 \mathrm{ppm} ; \mathrm{CD}_{2} \mathrm{Cl}_{2}: 5.32 \mathrm{ppm}$; and $\mathrm{CD}_{3} \mathrm{CN}: 1.940$ $\mathrm{ppm}) .{ }^{13} \mathrm{C}$ chemical shifts are also reported as $\delta(\mathrm{ppm})$ values downfield from $\mathrm{Me}_{4} \mathrm{Si}$, and chemical shifts were referenced to residual nondeuterated solvents peaks $\left(\mathrm{CDCl}_{3}: 77.160 \mathrm{ppm}\right.$, $\mathrm{C}_{6} \mathrm{D}_{6}: 128.060 \mathrm{ppm} ; \mathrm{CD}_{2} \mathrm{Cl}_{2}: 54.00 \mathrm{ppm}$; and $\mathrm{CD}_{3} \mathrm{CN}$ : $118.260 \mathrm{ppm})$. Proton coupling constants $(J)$ are given in hertz. The spectral coupling patterns are designated as follows: s/S-singlet; d/D-doublet; t/T-triplet; $q / Q$ - quartet; quint-quintet; sept-septet; hept-heptet; $\mathrm{m}$-multiplet; $\mathrm{dd}$-doublet of doublets; $\mathrm{dt}$-doublet of triplets; $\mathrm{td}$ - triplet of doublets; and br-broad signal. Quaternary carbons are designated as $\mathrm{C}_{\mathrm{q}}$.

Chemical shift assignment in the ${ }^{1} \mathrm{H}$ NMR spectra is based on first-order analysis experiments. The ${ }^{13} \mathrm{C}$ shifts were obtained from proton-decoupled ${ }^{13} \mathrm{C}$ NMR spectra. Where necessary, the multiplicities of the ${ }^{13} \mathrm{C}$ signals were deduced from proton-decoupled DEPT-135 spectra. The resonances of the proton-bearing carbon atoms were correlated with specific proton resonances using two-dimensional $\left({ }^{13} \mathrm{C}-{ }^{1} \mathrm{H}\right)$ heteronuclear single-quantum coherence experiments. Standard 
Bruker pulse programs $(298 \mathrm{~K})$ were used in the experiments, while low-temperature $(243 \mathrm{~K}) \mathrm{NMR}$ experiments were run for all of the fluxional 1,5-cyclooctadiene metal complexes.

Solution IR spectra $(\nu(\mathrm{CO}))$ were recorded on a Bruker $\alpha$ FTIR spectrophotometer with $\mathrm{CH}_{2} \mathrm{Cl}_{2}$ as solvent. The range of absorption measured was $4000-400 \mathrm{~cm}^{-1}$.

Electrospray mass spectroscopy (ESI-MS) images were recorded on a Bruker Q-TOF mass spectrometer with positive electron spray as the ionization techniques; nitrogen was employed as drying and nebulizing gas at a flow rate of $4 \mathrm{~L}$ / $\min$. The $\mathrm{m} / z$ values were measured in the range of $100-1500$ with acetonitrile as solvent. Accurate mass measurements were performed by using a Q-TOF premier mass spectrometer with electrospray source (Waters, Manchester, U.K.) operating at a resolution of ca. 16000 (full width at half-maximum).

Synthesis of $1 \mathrm{a}[\mathrm{Rh}(\mathrm{cod})(\mathrm{COC})]\left(\mathrm{PF}_{6}\right)$. Note: Attempts to obtain 1a via in situ deprotonation produced only traces of the desired compound. Herein, the entitled compound was obtained in two steps via transmetallation reaction from its corresponding bimetallic silver derivative $5\left[\mathrm{Ag}_{2} \mathrm{Cl}_{2}(\mathrm{COC})\right]$ (see vida infra).

To a Schlenk tube loaded with $5\left[\mathrm{Ag}_{2} \mathrm{Cl}_{2}(\mu\right.$-COC) $]$ (165 $\mathrm{mg}, 0.15 \mathrm{mmol}), \mathrm{KPF}_{6}(55 \mathrm{mg}, 0.30 \mathrm{mmol})$, and $[\mathrm{Rh}(\operatorname{cod}) \mathrm{Cl}]_{2}$ $(73 \mathrm{mg}, 0.15 \mathrm{mmol})$, dichloromethane (ca. $50 \mathrm{~mL}$ ) was added via cannula in a dark environment under stirring. The initial clear golden brown solution eventually changes to a murky orange solution over time. The reaction vessel was capped and the mixture was stirred overnight in the dark resulting in a murky orange solution the following morning. The solvent was removed in vacuo. By means of cannula filtration, the reaction mixture was washed with hexane and diethyl ether. Finally, compound 1a $[\mathrm{Rh}(\mathrm{cod})(\mathrm{COC})]\left(\mathrm{PF}_{6}\right)$ was extracted with dichloromethane, resulting in an orange solid $(108 \mathrm{mg}, 0.09$ mmol, 62\%) after solvent evaporation. The product was dried under vacuum at $50{ }^{\circ} \mathrm{C}$ overnight for NMR analysis.

${ }^{1} \mathrm{H}$ NMR: $\delta_{\mathrm{H}}\left(\mathrm{CDCl}_{3}, 500.13 \mathrm{MHz}\right) 7.60\left(\mathrm{~m}, 4 \mathrm{H}, \mathrm{ArH}_{\text {Dipp }}\right)$, 7.40 (d, 4H, J = 7.8 Hz, ArH $\left.\operatorname{Dipp}_{\text {) }}\right) 7.33(\mathrm{~d}, 4 \mathrm{H}, J=7.9 \mathrm{~Hz}$, $\mathrm{ArH}_{\text {Dipp }}$ ), 4.93 (br s, $4 \mathrm{H}, \mathrm{O}\left(\mathrm{CH}_{2}\right)_{2}$ ), 4.82 (br s, $2 \mathrm{H}$, cod-CH), 3.27 (br s, $2 \mathrm{H}$, cod-CH), 2.11 (sept, $J=6.5 \mathrm{~Hz}, 8 \mathrm{H}$, $\left.\mathrm{CH}\left(\mathrm{CH}_{3}\right)_{2}\right), 1.77$ (br s, $4 \mathrm{H}$, cod- $\mathrm{CH}_{2}$ ), 1.64 (br s, $4 \mathrm{H}$, cod$\left.\mathrm{CH}_{2}\right), 1.38\left(\mathrm{~s}, 12 \mathrm{H}, \mathrm{CH}\left(\mathrm{CH}_{3}\right)_{2}\right), 1.19\left(\mathrm{~s}, 12 \mathrm{H}, \mathrm{CH}\left(\mathrm{CH}_{3}\right)_{2}\right)$, $1.10\left(\mathrm{~d}, 12 \mathrm{H}, J=6.7 \mathrm{~Hz}, \mathrm{CH}\left(\mathrm{CH}_{3}\right)_{2}\right), 1.07(\mathrm{~d}, 12 \mathrm{H}, J=6.8$ $\left.\mathrm{Hz}, \mathrm{CH}\left(\mathrm{CH}_{3}\right)_{2}\right) .{ }^{13} \mathrm{C}$ NMR: $\delta_{\mathrm{C}}\left(\mathrm{CDCl}_{3}, 125.31 \mathrm{MHz}\right) 169.37$ $\left(\mathrm{d}, J=41.2 \mathrm{~Hz}, \mathrm{C}_{\text {carbene }}\right), 145.56\left(\mathrm{C}_{\mathrm{q} T \mathrm{Trz}}\right), 144.79\left(\mathrm{ArC}_{\mathrm{q}}\right)$, $144.72\left(\mathrm{ArC}_{\mathrm{q}}\right), 135.15\left(\mathrm{ArC}_{\mathrm{q}}\right), 132.34(\mathrm{ArCH}), 131.56$ $(\mathrm{ArCH}), 130.16\left(\mathrm{ArC}_{\mathrm{q}}\right), 124.74(\mathrm{ArCH}), 124.51(\mathrm{ArCH})$, 97.30 (cod-CH), 69.39 (d, $J=13.9 \mathrm{~Hz}$, cod-CH), 57.88 $\left(\mathrm{O}\left(\mathrm{CH}_{2}\right)_{2}\right), 32.86\left(\right.$ cod- $\left.\mathrm{CH}_{2}\right), 29.30\left(\mathrm{CH}\left(\mathrm{CH}_{3}\right)_{2}\right), 29.23$ $\left(\mathrm{CH}\left(\mathrm{CH}_{3}\right)_{2}\right), 28.42\left(\right.$ cod- $\left.\mathrm{CH}_{2}\right), 25.94\left(\mathrm{CH}\left(\mathrm{CH}_{3}\right)_{2}\right), 25.84$ $\left(\mathrm{CH}\left(\mathrm{CH}_{3}\right)_{2}\right), 23.72\left(\mathrm{CH}\left(\mathrm{CH}_{3}\right)_{2}\right), 22.81\left(\mathrm{CH}\left(\mathrm{CH}_{3}\right)_{2}\right) .{ }^{19} \mathrm{~F}$ NMR: $\delta_{\mathrm{F}}\left(\mathrm{CDCl}_{3}, 470.59 \mathrm{MHz}\right)-73.64(\mathrm{~d}, J=712.6 \mathrm{~Hz}$, PF 6$).{ }^{31} \mathrm{P}$ NMR: $\delta_{\mathrm{P}}\left(\mathrm{CDCl}_{3}, 202.46 \mathrm{MHz}\right)-144.31$ (sept, $J=$ $712.6 \mathrm{~Hz}, \mathrm{PF}_{6}$ ). HRMS (flow injection analysis (FIA)-ESI): calcd for $\left[\mathrm{C}_{62} \mathrm{H}_{84} \mathrm{~N}_{6} \mathrm{ORh}\right]^{+}\left[\mathrm{M}-\mathrm{PF}_{6}\right]^{+}$: 1031.5761; found: 1031.5783 .

Synthesis of $1 \mathbf{b}\left[\operatorname{Ir}(\operatorname{cod}) \mathrm{Cl}_{2}(\mathrm{COC})\right]$. An oven-dried Schlenk tube was loaded with $\left[\mathrm{H}_{2}(\mathbf{C O C})\right]\left(\mathrm{PF}_{6}\right)_{2}(369 \mathrm{mg}$, $0.33 \mathrm{mmol}), \mathrm{KHMDS}(165 \mathrm{mg}, 0.83 \mathrm{mmol})$, and $[\operatorname{Ir}(\mathrm{cod}) \mathrm{Cl}]_{2}$ $(222 \mathrm{mg}, 0.33 \mathrm{mmol})$. Dry THF (ca. $50 \mathrm{~mL}$ ) was added to the reaction mixture at $-78{ }^{\circ} \mathrm{C}$ under stirring in an inert atmosphere for $30 \mathrm{~min}$, whereafter the septum was removed and the Schlenk was capped. The reaction mixture was allowed to gradually warm to RT overnight. The reaction mixture turned from yellow-orange to a darker yellow-brown upon overnight reaction. The solvent was evaporated under reduced pressure followed by several washings with hexane and DEE, followed by cannula extraction with dichloromethane to afford compound $\mathbf{1 b}\left[\operatorname{Ir}(\operatorname{cod}) \mathrm{Cl}_{2}(\mathrm{COC})\right](0.26 \mathrm{~g}, 0.21 \mathrm{mmol}, 50 \%)$ as a bright orange solid. The product was dried overnight, under vacuum, at $50{ }^{\circ} \mathrm{C}$ for NMR analysis. Crystallization from a toluene/dichloromethane mixture yielded single crystals suitable for XRD analysis.

${ }^{1} \mathrm{H}$ NMR: $\delta_{\mathrm{H}}\left(\mathrm{CD}_{2} \mathrm{Cl}_{2}, 400.21 \mathrm{MHz}\right) 7.65(\mathrm{t}, 2 \mathrm{H}, J=7.8$ $\left.\mathrm{Hz}, \operatorname{ArH}_{\text {Dipp }}\right), 7.59\left(\mathrm{t}, 2 \mathrm{H}, J=7.8 \mathrm{~Hz}, \operatorname{ArH}_{\text {Dipp }}\right), 7.40(\mathrm{~d}, 6 \mathrm{H}, J$ $\left.=7.2 \mathrm{~Hz}, \operatorname{ArH}_{\text {Dipp }}\right), 7.32\left(\mathrm{~d}, 2 \mathrm{H}, J=7.7 \mathrm{~Hz}, \operatorname{ArH}_{\text {Dipp }}\right), 5.13(\mathrm{~d}$, $\left.2 \mathrm{H}, J=13.6 \mathrm{~Hz}, \mathrm{O}\left(\mathrm{CH}_{2}\right)_{2}\right), 4.35(\mathrm{~d}, 2 \mathrm{H}, J=13.6 \mathrm{~Hz}$, $\left.\mathrm{O}\left(\mathrm{CH}_{2}\right)_{2}\right), 4.06$ (br s, $2 \mathrm{H}$, cod-CH), $2.54\left(\mathrm{~m}, 4 \mathrm{H}\right.$, cod- $\left.\mathrm{CH}_{2}\right)$, $2.22\left(\mathrm{~m}, 4 \mathrm{H}, \mathrm{CH}\left(\mathrm{CH}_{3}\right)_{2}\right), 2.01\left(\mathrm{~m}, 4 \mathrm{H}, \mathrm{CH}\left(\mathrm{CH}_{3}\right)_{2}\right), 1.82(\mathrm{~m}$, $2 \mathrm{H}$, cod-CH), $1.44\left(\mathrm{~m}, 2 \mathrm{H}\right.$, cod- $\left.\mathrm{CH}_{2}\right), 1.31(\mathrm{~d}, 6 \mathrm{H}, J=6.3 \mathrm{~Hz}$, $\left.\mathrm{CH}\left(\mathrm{CH}_{3}\right)_{2}\right), 1.25$ (d, 6H, $\left.J=6.3 \mathrm{~Hz}, \mathrm{CH}\left(\mathrm{CH}_{3}\right)_{2}\right), 1.19$ (d, $\left.6 \mathrm{H}, \mathrm{J}=6.4 \mathrm{~Hz}, \mathrm{CH}\left(\mathrm{CH}_{3}\right)_{2}\right), 1.12\left(\mathrm{~m}, 26 \mathrm{H}, \mathrm{CH}\left(\mathrm{CH}_{3}\right)_{2}[24 \mathrm{H}]\right.$, cod- $\left.\mathrm{CH}_{2}[2 \mathrm{H}]\right), 0.93\left(\mathrm{~d}, 6 \mathrm{H}, \mathrm{J}=6.2 \mathrm{~Hz}, \mathrm{CH}\left(\mathrm{CH}_{3}\right)_{2}\right) .{ }^{13} \mathrm{C}$ NMR: $\delta_{\mathrm{C}}\left(\mathrm{CD}_{2} \mathrm{Cl}_{2}, 100.64 \mathrm{MHz}\right) 166.68$ ( $\left.\mathrm{C}_{\text {carbene }}\right), 145.74$ $\left(\mathrm{C}_{\mathrm{q} T r z}\right), 145.63\left(\mathrm{ArC}_{\mathrm{q}}\right), 144.95\left(\mathrm{ArC}_{\mathrm{q}}\right), 144.00\left(\mathrm{ArC}_{\mathrm{q}}\right) 141.89$ $\left(\mathrm{ArC}_{\mathrm{q}}\right), 135.04\left(\mathrm{ArC}_{\mathrm{q}}\right), 132.78(\mathrm{ArCH}), 131.76(\mathrm{ArCH})$, $128.59\left(\mathrm{ArC}_{\mathrm{q}}\right), 125.37(\mathrm{ArCH}), 125.08(\mathrm{ArCH}), 124.87$ $(\mathrm{ArCH}), 124.30(\mathrm{ArCH}), 73.77(\operatorname{cod}-\mathrm{CH}), 73.11(\operatorname{cod}-\mathrm{CH})$, $57.01\left(\mathrm{O}\left(\mathrm{CH}_{2}\right)_{2}\right), 35.17\left(\operatorname{cod}-\mathrm{CH}_{2}\right), 29.53\left(\mathrm{CH}\left(\mathrm{CH}_{3}\right)_{2}\right)$, $29.53\left(\mathrm{CH}\left(\mathrm{CH}_{3}\right)_{2}\right), 29.47\left(\mathrm{CH}\left(\mathrm{CH}_{3}\right)_{2}\right), 29.28\left(\mathrm{CH}\left(\mathrm{CH}_{3}\right)_{2}\right)$, $27.06\left(\operatorname{cod}-\mathrm{CH}_{2}\right), 26.00\left(\mathrm{CH}\left(\mathrm{CH}_{3}\right)_{2}\right), 25.53\left(\mathrm{CH}\left(\mathrm{CH}_{3}\right)_{2}\right)$, $24.71\left(\mathrm{CH}\left(\mathrm{CH}_{3}\right)_{2}\right), 24.47\left(\mathrm{CH}\left(\mathrm{CH}_{3}\right)_{2}\right), 23.73\left(\mathrm{CH}\left(\mathrm{CH}_{3}\right)_{2}\right)$, $23.66\left(\mathrm{CH}\left(\mathrm{CH}_{3}\right)_{2}\right), 23.11\left(\mathrm{CH}\left(\mathrm{CH}_{3}\right)_{2}\right), 21.56\left(\mathrm{CH}\left(\mathrm{CH}_{3}\right)_{2}\right)$. ${ }^{19} \mathrm{~F}$ NMR: $\delta_{\mathrm{F}}\left(\mathrm{CD}_{2} \mathrm{Cl}_{2}, 376.57 \mathrm{MHz}\right)-73.64(\mathrm{~d}, J=710.0 \mathrm{~Hz}$, PF $\left.{ }_{6}\right) .{ }^{31}$ P NMR: $\delta_{\mathrm{P}}\left(\mathrm{CD}_{2} \mathrm{Cl}_{2}, 162.01 \mathrm{MHz}\right)-144.52$ (sept, $J=$ $710.24 \mathrm{~Hz}, \mathrm{PF}_{6}$ ). HRMS (FIA-ESI): calcd for $\left[\mathrm{C}_{62} \mathrm{H}_{84} \mathrm{~N}_{6} \mathrm{OIr}\right]^{+}$ $\left[\mathrm{M}-\mathrm{PF}_{6}\right]^{+}:$1121.6336; found: 1121.6274 .

Synthesis of $2 \mathrm{a}\left[\mathrm{Rh}(\mathrm{CO})_{2}(\mathrm{COC})\right]\left(\mathrm{PF}_{6}\right)$. The entitled compound was synthesized according to the same procedure described for compound 1a $[\mathrm{Rh}(\operatorname{cod})(\mathrm{COC})]\left(\mathrm{PF}_{6}\right)$. To a Schlenk tube loaded with $5\left[\mathrm{Ag}_{2} \mathrm{Cl}_{2}(\mathrm{COC})\right](206 \mathrm{mg}, 0.18$ $\mathrm{mmol}), \mathrm{KPF}_{6}(68 \mathrm{mg}, 0.37 \mathrm{mmol})$, and $\left[\mathrm{Rh}(\mathrm{CO})_{2} \mathrm{Cl}\right]_{2}(72$ $\mathrm{mg}, 0.18 \mathrm{mmol}$ ), dichloromethane (ca. $50 \mathrm{~mL}$ ) was added via cannula in a dark environment. The color of the reaction contents changed from the initial dark brown to orange-brown within a few minutes. The reaction vessel was capped and the reaction was stirred overnight, resulting in a yellow-brown solution the following morning. The solvent was removed in vacuo. By means of cannula filtration, the reaction mixture was washed with hexane and diethyl ether. Finally, compound 2a was extracted with dichloromethane, resulting in an orangebrown solid (142 mg, $0.13 \mathrm{mmol}, 68 \%$ ) after solvent evaporation.

Trace amounts of $\mathbf{2 a}$ could also be isolated from the reaction procedure to prepare $4 \mathbf{a}\left[\mathrm{Rh}_{2}(\mathrm{CO})_{4} \mathrm{Cl}_{2}(\mu\right.$-COC $\left.)\right]$, using 0.5 equiv of metal precursor $[\mathrm{Rh}(\mathrm{cod}) \mathrm{Cl}]_{2}$, followed by treatment with $\mathrm{CO}(\mathrm{g})$ as described above. After cannula extraction of $\mathbf{4 a}$ $\left[\mathrm{Rh}_{2}(\mathrm{CO})_{4} \mathrm{Cl}_{2}(\mu\right.$-COC $\left.)\right]$ from the reaction mixture in solvents hexane and DEE, the residue was extracted with dichloromethane to yield a mixture of unreacted $\left[\mathrm{H}_{2}(\mathbf{C O C})\right]\left(\mathrm{PF}_{6}\right)_{2}$ and 2a. Recrystallization of this fraction yielded single crystals of $\mathbf{2 a}\left[\mathrm{Rh}(\mathrm{CO})_{2}(\mathrm{COC})\right]\left(\mathrm{PF}_{6}\right)$, which were analyzed by X-ray diffraction, HRMS, and FTIR spectroscopy.

${ }^{1} \mathrm{H}$ NMR: $\delta_{\mathrm{H}}\left(\mathrm{CDCl}_{3}, 500.13 \mathrm{MHz}\right) 7.66\left(\mathrm{~m}, 4 \mathrm{H}, \mathrm{ArH}_{\text {Dipp }}\right)$, $7.40\left(\mathrm{~m}, 8 \mathrm{H}, \operatorname{ArH}_{\text {Dipp }}\right), 4.29\left(\mathrm{~d}, 2 \mathrm{H}, J=13.6 \mathrm{~Hz}, \mathrm{O}\left(\mathrm{CH}_{2}\right)_{2}\right)$, $4.24\left(\mathrm{~d}, 2 \mathrm{H}, J=13.5 \mathrm{~Hz}, \mathrm{O}\left(\mathrm{CH}_{2}\right)_{2}\right), 2.69$ (sept, $2 \mathrm{H}, J=6.8$ $\left.\mathrm{Hz}, \mathrm{CH}\left(\mathrm{CH}_{3}\right)_{2}\right), 2.31$ (sept, $\left.2 \mathrm{H}, J=6.7 \mathrm{~Hz}, \mathrm{CH}\left(\mathrm{CH}_{3}\right)_{2}\right), 2.14$ 
(sept, $\left.2 \mathrm{H}, J=6.8 \mathrm{~Hz}, \mathrm{CH}\left(\mathrm{CH}_{3}\right)_{2}\right), 1.96$ (sept, $2 \mathrm{H}, J=6.7 \mathrm{~Hz}$, $\left.\mathrm{CH}\left(\mathrm{CH}_{3}\right)_{2}\right), 1.42\left(\mathrm{~d}, 6 \mathrm{H}, \mathrm{J}=6.8 \mathrm{~Hz}, \mathrm{CH}\left(\mathrm{CH}_{3}\right)_{2}\right), 1.27$ (d, $\left.6 \mathrm{H}, J=6.9 \mathrm{~Hz}, \mathrm{CH}\left(\mathrm{CH}_{3}\right)_{2}\right), 1.25(\mathrm{~d}, 6 \mathrm{H}, J=6.8 \mathrm{~Hz}$, $\left.\mathrm{CH}\left(\mathrm{CH}_{3}\right)_{2}\right), 1.20\left(\mathrm{dd}, 12 \mathrm{H}, J=7.1,7.1 \mathrm{~Hz}, \mathrm{CH}\left(\mathrm{CH}_{3}\right)_{2}\right), 1.14$ $\left(\mathrm{d}, 6 \mathrm{H}, J=6.7 \mathrm{~Hz}, \mathrm{CH}\left(\mathrm{CH}_{3}\right)_{2}\right), 1.09(\mathrm{dd}, 12 \mathrm{H}, J=6.9,6.8 \mathrm{~Hz}$, $\left.\mathrm{CH}\left(\mathrm{CH}_{3}\right)_{2}\right) .{ }^{13} \mathrm{C}$ NMR: $\delta_{\mathrm{C}}\left(\mathrm{CDCl}_{3}, 125.31 \mathrm{MHz}\right) 183.82(\mathrm{~d}, J$ $\left.=56.4 \mathrm{~Hz}, \mathrm{Rh}-(\mathrm{CO})_{2}\right), 167.59\left(\mathbf{C}_{\text {carbene }}\right), 146.48\left(\mathbf{C}_{\mathrm{q} \text { Trz }}\right)$, $146.38\left(\mathrm{C}_{\mathrm{q} T r z}\right)$ 145.53 $\left(\operatorname{ArC}_{\mathrm{q}}\right), 144.67\left(\mathrm{ArC}_{\mathrm{q}}\right) 143.57\left(\mathrm{ArC}_{\mathrm{q}}\right)$, $143.54\left(\mathrm{ArC}_{\mathrm{q}}\right), 135.44\left(\mathrm{ArC}_{\mathrm{q}}\right), 133.22(\mathrm{ArCH}), 132.79$ $(\mathrm{ArCH}), 128.44\left(\mathrm{ArC}_{\mathrm{q}}\right), 125.39(\mathrm{ArCH}), 124.98(\mathrm{ArCH})$, $124.98(\mathrm{ArCH}), 124.98(\mathrm{ArCH}), 55.44\left(\mathrm{O}\left(\mathrm{CH}_{2}\right)_{2}\right), 29.85$ $\left(\mathrm{CH}\left(\mathrm{CH}_{3}\right)_{2}\right), 29.77\left(\mathrm{CH}\left(\mathrm{CH}_{3}\right)_{2}\right), 29.51\left(\mathrm{CH}\left(\mathrm{CH}_{3}\right)_{2}\right), 29.23$ $\left(\mathrm{CH}\left(\mathrm{CH}_{3}\right)_{2}\right), 26.38\left(\mathrm{CH}\left(\mathrm{CH}_{3}\right)_{2}\right), 25.58\left(\mathrm{CH}\left(\mathrm{CH}_{3}\right)_{2}\right), 24.89$ $\left(\mathrm{CH}\left(\mathrm{CH}_{3}\right)_{2}\right), 24.69\left(\mathrm{CH}\left(\mathrm{CH}_{3}\right)_{2}\right), 23.52\left(\mathrm{CH}\left(\mathrm{CH}_{3}\right)_{2}\right), 23.41$ $\left(\mathrm{CH}\left(\mathrm{CH}_{3}\right)_{2}\right), 22.54\left(\mathrm{CH}\left(\mathrm{CH}_{3}\right)_{2}\right), 22.51\left(\mathrm{CH}\left(\mathrm{CH}_{3}\right)_{2}\right) \cdot{ }^{19} \mathrm{~F}$ NMR: $\delta_{\mathrm{F}}\left(\mathrm{CDCl}_{3}, 470.59 \mathrm{MHz}\right)-73.54(\mathrm{~d}, J=712.3 \mathrm{~Hz}$, PF 6$).{ }^{31}$ P NMR: $\delta_{\mathrm{P}}\left(\mathrm{CDCl}_{3}, 202.46 \mathrm{MHz}\right)-144.33$ (sept, $J=$ $712.9 \mathrm{~Hz}, \mathrm{PF}_{6}$ ). HRMS (FIA-ESI): calcd for $\left[\mathrm{C}_{62} \mathrm{H}_{84} \mathrm{~N}_{6} \mathrm{ORh}\right]^{+}$ $\left[\mathrm{M}-\mathrm{PF}_{6}\right]^{+}$: 979.4721; found: 979.4963. FTIR $\nu_{\mathrm{CO}}\left(\mathrm{CH}_{2} \mathrm{Cl}_{2}\right)$ : 2016, $1998 \mathrm{~cm}^{-1}$.

Synthesis of $2 \mathrm{~b}\left[\operatorname{Ir}(\mathrm{CO})_{2}(\mathrm{COC})\right]\left(\mathrm{PF}_{6}\right)$. Compound $2 \mathbf{b}$ was obtained by substitution of the 1,5-cyclooctadiene (cod) ligand of $\mathbf{1 b}[\operatorname{Ir}(\mathrm{cod})(\mathrm{COC})]\left(\mathrm{PF}_{6}\right)$. A dichloromethane solution of compound $\mathbf{1 b}(0.26 \mathrm{~g}, 0.21 \mathrm{mmol})$ was treated with $\mathrm{CO}(\mathrm{g})$ for $1 \mathrm{~h}$, resulting in a color change from an intense red-orange to yellow-green. After solvent removal, product $\mathbf{2 b}$ [Ir$\left.(\mathrm{CO})_{2}(\mathrm{COC})\right]\left(\mathrm{PF}_{6}\right)(0.25 \mathrm{~g}, 0.21 \mathrm{mmol}, 100 \%)$ was obtained as a light yellow-green solid. The product was dried under vacuum at $50{ }^{\circ} \mathrm{C}$ overnight for NMR analysis. Crystallization from $\mathrm{CDCl}_{3}$ yielded single crystals suitable for XRD analysis.

${ }^{1} \mathrm{H}$ NMR: $\delta_{\mathrm{H}}\left(\mathrm{CD}_{2} \mathrm{Cl}_{2}, 500.13 \mathrm{MHz}\right) 7.71$ (d, 2H, $J=7.9$ $\mathrm{Hz}, \operatorname{ArH}_{\text {Dipp }}$ ), 7.67 (d, 2H, J = 7.9 Hz, $\operatorname{ArH}_{\text {Dipp }}$ ), 7.47 (d, 4H, J $\left.=7.8 \mathrm{~Hz}, \operatorname{ArH}_{\text {Dipp }}\right), 7.43\left(\mathrm{~d}, 4 \mathrm{H}, J=7.8 \mathrm{~Hz}, \operatorname{ArH}_{\text {Dipp }}\right), 4.35$ (d, $\left.2 \mathrm{H}, J=13.5 \mathrm{~Hz}, \mathrm{O}\left(\mathrm{CH}_{2}\right)_{2}\right), 4.22(\mathrm{~d}, 2 \mathrm{H}, J=13.5 \mathrm{~Hz}$, $\left.\mathrm{O}\left(\mathrm{CH}_{2}\right)_{2}\right), 2.63$ (sept, $\left.2 \mathrm{H}, J=6.8 \mathrm{~Hz}, \mathrm{CH}\left(\mathrm{CH}_{3}\right)_{2}\right), 2.31$ (sept, $\left.2 \mathrm{H}, J=6.8 \mathrm{~Hz}, \mathrm{CH}\left(\mathrm{CH}_{3}\right)_{2}\right), 2.14$ (sept, $2 \mathrm{H}, J=6.8 \mathrm{~Hz}$, $\left.\mathrm{CH}\left(\mathrm{CH}_{3}\right)_{2}\right), 1.97$ (sept, $\left.2 \mathrm{H}, J=6.8 \mathrm{~Hz}, \mathrm{CH}\left(\mathrm{CH}_{3}\right)_{2}\right), 1.40$ (d, $\left.6 \mathrm{H}, J=6.8 \mathrm{~Hz}, \mathrm{CH}\left(\mathrm{CH}_{3}\right)_{2}\right), 1.27(\mathrm{dd}, 12 \mathrm{H}, J=6.9,6.9 \mathrm{~Hz}$, $\left.\mathrm{CH}\left(\mathrm{CH}_{3}\right)_{2}\right), 1.21\left(\mathrm{dd}, 12 \mathrm{H}, J=6.7,6.7 \mathrm{~Hz}, \mathrm{CH}\left(\mathrm{CH}_{3}\right)_{2}\right), 1.14$ $\left(\mathrm{d}, 6 \mathrm{H}, J=6.8 \mathrm{~Hz}, \mathrm{CH}\left(\mathrm{CH}_{3}\right)_{2}\right), 1.11(\mathrm{~d}, 6 \mathrm{H}, J=6.8 \mathrm{~Hz}$, $\left.\mathrm{CH}\left(\mathrm{CH}_{3}\right)_{2}\right), 1.08\left(\mathrm{~d}, 6 \mathrm{H}, \mathrm{J}=6.9 \mathrm{~Hz}, \mathrm{CH}\left(\mathrm{CH}_{3}\right)_{2}\right) .{ }^{13} \mathrm{C} \mathrm{NMR}$ : $\delta_{\mathrm{C}}\left(\mathrm{CD}_{2} \mathrm{Cl}_{2}, 125.31 \mathrm{MHz}\right) \quad 176.46\left(\mathrm{Ir}-(\mathrm{CO})_{2}\right), \quad 166.17$ $\left(\mathrm{C}_{\text {carbene }}\right), 146.83\left(\mathrm{C}_{\mathrm{q} \text { Trz }}\right), 146.79\left(\mathrm{ArC}_{\mathrm{q}}\right), 146.28\left(\mathrm{ArC}_{\mathrm{q}}\right)$ $145.17\left(\mathrm{ArC}_{\mathrm{q}}\right), 144.74\left(\mathrm{ArC}_{\mathrm{q}}\right), 135.25\left(\mathrm{ArC}_{\mathrm{q}}\right), 133.77$ $(\mathrm{ArCH}), 133.40(\mathrm{ArCH}), 128.65\left(\mathrm{ArC}_{\mathrm{q}}\right), 125.91(\mathrm{ArCH})$, $125.62(\mathrm{ArCH}), 125.56(\mathrm{ArCH}), 125.42(\mathrm{ArCH}), 55.63$ $\left(\mathrm{O}\left(\mathrm{CH}_{2}\right)_{2}\right), 30.48\left(\mathrm{CH}\left(\mathrm{CH}_{3}\right)_{2}\right), 30.26\left(\mathrm{CH}\left(\mathrm{CH}_{3}\right)_{2}\right), 30.08$ $\left(\mathrm{CH}\left(\mathrm{CH}_{3}\right)_{2}\right), 29.73\left(\mathrm{CH}\left(\mathrm{CH}_{3}\right)_{2}\right), 25.78\left(\mathrm{CH}\left(\mathrm{CH}_{3}\right)_{2}\right), 25.12$ $\left(\mathrm{CH}\left(\mathrm{CH}_{3}\right)_{2}\right), 24.98\left(\mathrm{CH}\left(\mathrm{CH}_{3}\right)_{2}\right), 23.72\left(\mathrm{CH}\left(\mathrm{CH}_{3}\right)_{2}\right), 23.72$ $\left(\mathrm{CH}\left(\mathrm{CH}_{3}\right)_{2}\right), 23.72\left(\mathrm{CH}\left(\mathrm{CH}_{3}\right)_{2}\right) 22.79\left(\mathrm{CH}\left(\mathrm{CH}_{3}\right)_{2}\right), 22.67$ $\left(\mathrm{CH}\left(\mathrm{CH}_{3}\right)_{2}\right) .{ }^{19} \mathrm{~F}$ NMR: $\delta_{\mathrm{F}}\left(\mathrm{CDCl}_{3}, 470.59 \mathrm{MHz}\right)-73.53(\mathrm{~d}$, $\left.J=712.4 \mathrm{~Hz}, \mathrm{PF}_{6}\right) .{ }^{31} \mathrm{P}$ NMR: $\delta_{\mathrm{P}}\left(\mathrm{CDCl}_{3}, 202.46 \mathrm{MHz}\right)$ -144.38 (sept, $J=712.3 \mathrm{~Hz}, \mathrm{PF}_{6}$ ). HRMS (FIA-ESI): calcd for $\left[\mathrm{C}_{56} \mathrm{H}_{72} \mathrm{~N}_{6} \mathrm{O}_{3} \mathrm{Ir}\right]^{+}\left[\mathrm{M}-\mathrm{PF}_{6}\right]^{+}:$1069.5295; found: 1069.5167. FTIR $\nu_{\mathrm{CO}}\left(\mathrm{CH}_{2} \mathrm{Cl}_{2}\right): 2065,1999 \mathrm{~cm}^{-1}$.

Synthesis of $3 a\left[\mathrm{Rh}_{2}(\mathrm{cod})_{2} \mathrm{Cl}_{2}(\boldsymbol{\mu}-\mathrm{COC})\right]$. Complex 3a could be prepared using either one of two different synthetic methods: (1) a one-pot deprotonation and metallation approach and (2) generation of the free carbene with subsequent metallation.

Method 1. An oven-dried Schlenk tube was loaded with $\left[\mathrm{H}_{2}(\mathrm{COC})\right]\left(\mathrm{PF}_{6}\right)_{2}(532 \mathrm{mg}, 0.48 \mathrm{mmol}), \mathrm{KHMDS}(238 \mathrm{mg}$, $1.19 \mathrm{mmol})(\mathrm{KHMDS}=$ potassium hexamethyldisilazide $)$, and
$[\mathrm{Rh}(\operatorname{cod}) \mathrm{Cl}]_{2}(283 \mathrm{mg}, 0.57 \mathrm{mmol})$. Dry THF (ca. $50 \mathrm{~mL}$ ) was added to the dry contents at $-78{ }^{\circ} \mathrm{C}$ under stirring in an inert atmosphere for $30 \mathrm{~min}$, whereafter the septum was removed and the Schlenk tube was capped. The reaction mixture was allowed to gradually warm to RT overnight. The reaction mixture turned from orange-brown to bright yellow upon overnight reaction.

Method 2. An oven-dried Schlenk tube was loaded with $\left[\mathrm{H}_{2}(\mathrm{COC})\right]\left(\mathrm{PF}_{6}\right)_{2}(479 \mathrm{mg}, 0.41 \mathrm{mmol})$ and KHMDS (215 $\mathrm{mg}, 1.08 \mathrm{mmol}$ ), to which was added degassed dry THF (ca. $40 \mathrm{~mL}$ ) at $-78^{\circ} \mathrm{C}$ under stirring, and the color of the solution changed to dark purple upon triazolium deprotonation and in situ generation of the free biscarbene. After stirring for $2 \mathrm{~min}$, $[\mathrm{Rh}(\text { cod }) \mathrm{Cl}]_{2}(255 \mathrm{mg}, 0.52 \mathrm{mmol})$ dissolved in THF (ca. 10 $\mathrm{mL}$ ) was transferred to the reaction mixture at low temperature. The reaction mixture changed color from purple to orange-brown. The reaction was allowed to react for $30 \mathrm{~min}$ before the septum was removed and the Schlenk tube was capped for overnight reaction, gradually heating to RT. The color again changed from orange-brown to bright yellow upon overnight reaction.

For both methods 1 and 2, the reaction workup involved evaporation of the solvent and washing with solvents hexane and diethyl ether. Extraction with dichloromethane afforded compound 3a $\left[\mathrm{Rh}_{2}(\mathrm{cod})_{2} \mathrm{Cl}_{2}(\mu\right.$-COC $\left.)\right](0.4 \mathrm{~g}, 0.32 \mathrm{mmol}$, $66 \%$-method $1 ; 0.4 \mathrm{~g}, 0.30 \mathrm{mmol}, 69 \%$-method 2) as a bright yellow solid. Crystallization from $\mathrm{CDCl}_{3}$ yielded single crystals suitable for XRD analysis.

${ }^{1} \mathrm{H}$ NMR: $\delta_{\mathrm{H}}\left(\mathrm{CDCl}_{3}, 400.21 \mathrm{MHz}\right) 7.56(\mathrm{dd}, 4 \mathrm{H}, J=7.5$ $\mathrm{Hz}, \operatorname{ArH}_{\text {Dipp }}$ ), 7.44 (d, 2H, J = 7.3 Hz, $\operatorname{ArH}_{\text {Dipp }}$ ), 7.30 (d, 4H, J $\left.=7.1 \mathrm{~Hz}, \operatorname{ArH}_{\text {Dipp }}\right), 7.25$ (d, 2H, $J=8.6 \mathrm{~Hz}, \operatorname{ArH}_{\text {Dipp }}$ ), 5.68 (d, $\left.2 \mathrm{H}, \mathrm{J}=11.4 \mathrm{~Hz}, \mathrm{O}\left(\mathrm{CH}_{2}\right)_{2}\right), 4.77$ (br s, $2 \mathrm{H}$, cod- $\left.\mathrm{CH}\right), 4.67$ (d, $4 \mathrm{H}, J=11.5 \mathrm{~Hz}$, cod-CH [2H], O $\left.\left(\mathrm{CH}_{2}\right)_{2}[2 \mathrm{H}]\right), 3.30$ (br s, $2 \mathrm{H}$, cod- $\mathrm{CH}_{2}$ ), $3.25\left(\mathrm{t}, 2 \mathrm{H}, J=6.0 \mathrm{~Hz}\right.$, cod- $\mathrm{CH}_{2}$ ), 2.85 (br s, $2 \mathrm{H}$, cod-CH), $2.45\left(\mathrm{t}, 2 \mathrm{H}, \mathrm{J}=5.4 \mathrm{~Hz}\right.$, cod- $\mathrm{CH}_{2}$ ), 1.95 (sept, $\left.4 \mathrm{H}, J=6.2 \mathrm{~Hz} \mathrm{CH}\left(\mathrm{CH}_{3}\right)_{2}\right), 1.86$ (sept, $4 \mathrm{H}, J=7.2 \mathrm{~Hz}$, $\left.\mathrm{CH}\left(\mathrm{CH}_{3}\right)_{2}\right), 1.58$ (br s, $2 \mathrm{H}$, cod- $\left.\mathrm{CH}_{2}\right), 1.53(\mathrm{~d}, 6 \mathrm{H}, J=6.0$ $\mathrm{Hz}$, cod- $\mathrm{CH}_{2}$ ), 1.45 (br s, $4 \mathrm{H}, \operatorname{cod}-\mathrm{CH}_{2}$ ), 1.26 (br s, $5 \mathrm{H}$, $\left.\mathrm{CH}\left(\mathrm{CH}_{3}\right)_{2}\right), 1.19\left(\mathrm{dd}, 12 \mathrm{H}, \mathrm{J}=6.2,6.3 \mathrm{~Hz}, \mathrm{CH}\left(\mathrm{CH}_{3}\right)_{2}\right), 1.13$ $\left(\mathrm{d}, 7 \mathrm{H}, J=6.5 \mathrm{~Hz}, \mathrm{CH}\left(\mathrm{CH}_{3}\right)_{2}\right), 1.07$ (br s, $\left.12 \mathrm{H}, \mathrm{CH}\left(\mathrm{CH}_{3}\right)_{2}\right)$, $1.01\left(\mathrm{dd}, 12 \mathrm{H}, J=9.1,7.2 \mathrm{~Hz}, \mathrm{CH}\left(\mathrm{CH}_{3}\right)_{2}\right) .{ }^{13} \mathrm{C}$ NMR: $\delta_{\mathrm{C}}$ $\left(\mathrm{CDCl}_{3}, 100.64 \mathrm{MHz}\right) 176.08\left(\mathrm{~d}, J=46.8 \mathrm{~Hz}, \mathrm{C}_{\text {carbene }}\right), 147.29$ $\left(\mathrm{C}_{\mathrm{q} T r z}\right), 146.65\left(\operatorname{ArC}_{\mathrm{q}}\right), 145.90\left(\operatorname{ArC}_{\mathrm{q}}\right), 144.91\left(\operatorname{ArC}_{\mathrm{q}}\right) 144.59$ $\left(\mathrm{ArC}_{\mathrm{q}}\right), 135.17\left(\mathrm{ArC}_{\mathrm{q}}\right), 132.10(\mathrm{ArCH}), 130.74(\mathrm{ArCH})$, $129.74\left(\mathrm{ArC}_{\mathrm{q}}\right), 124.73(\mathrm{ArCH}), 124.54(\mathrm{ArCH}), 124.20$ $(\mathrm{ArCH}), 122.88(\mathrm{ArCH}), 95.77(\mathrm{~d}, J=7.2 \mathrm{~Hz}, \operatorname{cod}-\mathrm{CH})$, $94.96(\mathrm{~d}, J=7.0 \mathrm{~Hz}$, cod-CH), $67.47(\mathrm{dd}, J=14.8,13.8 \mathrm{~Hz}$, cod- $\mathrm{CH}), 64.56\left(\mathrm{O}\left(\mathrm{CH}_{2}\right)_{2}\right), 33.12\left(\right.$ cod- $\left.\mathrm{CH}_{2}\right), 32.38$ (cod$\left.\mathrm{CH}_{2}\right), 28.84\left(\mathrm{CH}\left(\mathrm{CH}_{3}\right)_{2}\right), 28.84\left(\mathrm{CH}\left(\mathrm{CH}_{3}\right)_{2}\right), 28.73$ (cod$\left.\mathrm{CH}_{2}\right), 28.64\left(\mathrm{CH}\left(\mathrm{CH}_{3}\right)_{2}\right), 28.64\left(\right.$ cod- $\left.\mathrm{CH}_{2}\right), 28.34(\mathrm{CH}-$ $\left.\left(\mathrm{CH}_{3}\right)_{2}\right), 26.99\left(\mathrm{CH}\left(\mathrm{CH}_{3}\right)_{2}\right), 25.99\left(\mathrm{CH}\left(\mathrm{CH}_{3}\right)_{2}\right), 25.58$ $\left(\mathrm{CH}\left(\mathrm{CH}_{3}\right)_{2}\right), 25.16\left(\mathrm{CH}\left(\mathrm{CH}_{3}\right)_{2}\right), 24.32\left(\mathrm{CH}\left(\mathrm{CH}_{3}\right)_{2}\right), 24.32$ $\left(\mathrm{CH}\left(\mathrm{CH}_{3}\right)_{2}\right), 24.03\left(\mathrm{CH}\left(\mathrm{CH}_{3}\right)_{2}\right), 22.95\left(\mathrm{CH}\left(\mathrm{CH}_{3}\right)_{2}\right)$. HRMS (FIA-ESI): calcd for $\left[\mathrm{C}_{70} \mathrm{H}_{96} \mathrm{~N}_{6} \mathrm{ORh}_{2}\right]^{2+}[\mathrm{M}-2 \mathrm{Cl}]^{2+}$ : 621.2877; found: 621.2769, and $\left[\mathrm{C}_{70} \mathrm{H}_{96} \mathrm{~N}_{6} \mathrm{OClRh}_{2}\right][\mathrm{M}-$ $\mathrm{Cl}]^{+}$: 1277.5444; found: 1277.5303 .

Synthesis of $4 a\left[\mathrm{Rh}_{2}(\mathrm{CO})_{4} \mathrm{Cl}_{2}(\mu-\mathrm{COC})\right]$. Compound $4 \mathrm{a}$ could be prepared from either of two synthetic pathways: (1) directly from $\left[\mathrm{Rh}(\mathrm{CO})_{2} \mathrm{Cl}\right]_{2}$ and $(2)$ by substitution of the 1,5 cyclooctadiene (cod) ligand of compound 3 a $\left[\mathrm{Rh}_{2}(\operatorname{cod})_{2} \mathrm{Cl}_{2}(\mu\right.$-COC $\left.)\right]$ with two carbonyl ligands. For synthetic pathway 1 , a one-pot deprotonation and metallation 
approach as well as the generation of the free carbene with subsequent metallation led to the formation of product $4 a$.

Method 1. An oven-dried Schlenk tube was loaded with $\left[\mathrm{H}_{2}(\mathbf{C O C})\right]\left(\mathrm{PF}_{6}\right)_{2}(524 \mathrm{mg}, 0.47 \mathrm{mmol}), \mathrm{KHMDS}(207 \mathrm{mg}$, $1.04 \mathrm{mmol})$, and $\left[\mathrm{Rh}(\mathrm{CO})_{2} \mathrm{Cl}\right]_{2}(169 \mathrm{mg}, 0.44 \mathrm{mmol})$ and submerged in a cold bath at $-78{ }^{\circ} \mathrm{C}$ under stirring. Anhydrous THF (ca. $50 \mathrm{~mL}$ ) was transferred via cannula to the Schlenk tube under stirring in an inert atmosphere. The reaction was allowed to react for $30 \mathrm{~min}$ before the septum was removed, and the Schlenk tube was capped for overnight reaction, gradually heating to RT. The reaction mixture turned from dark brown to orange-brown. The product was isolated by evaporating the solvent and cannula extraction with dichloromethane following washing with hexane and DEE. Compound 4a $\left[\mathrm{Rh}_{2}(\mathrm{CO})_{4} \mathrm{Cl}_{2}(\mu\right.$-COC $\left.)\right](0.3 \mathrm{~g}, 0.25 \mathrm{mmol}, 53 \%)$ was isolated as a light yellow solid. Crystallization from $\mathrm{CDCl}_{3}$ yielded single crystals suitable for XRD analysis.

Method 2. Compound 4a could also be obtained by converting compound $3 \mathrm{a}\left[\mathrm{Rh}_{2}(\operatorname{cod})_{2} \mathrm{Cl}_{2}(\mu\right.$-COC $\left.)\right]$ by bubbling $\mathrm{CO}(\mathrm{g})$ through a dichloromethane solution of compound $3 \mathrm{a}(0.41 \mathrm{~g}, 0.32 \mathrm{mmol})$ for $1 \mathrm{~h}$, resulting in a color change from light orange to yellow. After solvent removal, product $4 \mathrm{a}\left[\mathrm{Rh}_{2}(\mathrm{CO}){ }_{4} \mathrm{Cl}_{2}(\mu\right.$-COC) $](0.38 \mathrm{~g}, 0.32$ mmol, 100\%) was obtained as a yellow solid. Crystallization from $\mathrm{CDCl}_{3}$ yielded single crystals suitable for XRD analysis.

${ }^{1} \mathrm{H}$ NMR: $\delta_{\mathrm{H}}\left(\mathrm{CDCl}_{3}, 500.13 \mathrm{MHz}\right) 7.57$ (m, 4H, ArH $\left.\mathrm{Dipp}_{\text {) }}\right)$, $7.35\left(\mathrm{dd}, 8 \mathrm{H}, J=6.7,6.7 \mathrm{~Hz}, \operatorname{ArH}_{\text {Dipp }}\right), 4.62(\mathrm{~s}, 4 \mathrm{H}$, $\left.\mathrm{O}\left(\mathrm{CH}_{2}\right)_{2}\right), 2.57$ (sept, $\left.4 \mathrm{H}, J=6.1 \mathrm{~Hz}, \mathrm{CH}\left(\mathrm{CH}_{3}\right)_{2}\right), 2.23$ (sept, $\left.4 \mathrm{H}, J=6.1 \mathrm{~Hz}, \mathrm{CH}\left(\mathrm{CH}_{3}\right)_{2}\right), 1.37(\mathrm{~d}, 12 \mathrm{H}, J=5.8 \mathrm{~Hz}$, $\left.\mathrm{CH}\left(\mathrm{CH}_{3}\right)_{2}\right), 1.19\left(\mathrm{~d}, 12 \mathrm{H}, J=5.9 \mathrm{~Hz}, \mathrm{CH}\left(\mathrm{CH}_{3}\right)_{2}\right), 1.09(\mathrm{dd}$, $\left.24 \mathrm{H}, J=7.2,7.2 \mathrm{~Hz}, \mathrm{CH}\left(\mathrm{CH}_{3}\right)_{2}\right) .{ }^{13} \mathrm{C} \mathrm{NMR}: \delta_{\mathrm{C}}\left(\mathrm{CDCl}_{3}\right.$, $125.31 \mathrm{MHz}) 185.75\left(\mathrm{~d}, J=54.5 \mathrm{~Hz}, \mathrm{Rh}-\mathrm{CO}_{\text {trans carbene }}\right)$, $183.40\left(\mathrm{~d}, J=74.6 \mathrm{~Hz}, \mathrm{Rh}-\mathrm{CO}_{\text {trans } \mathrm{Cl}}\right), 170.00(\mathrm{~d}, J=41.1 \mathrm{~Hz}$, $\left.\mathrm{C}_{\text {carbene }}\right), 146.35\left(\mathrm{C}_{\mathrm{q} T \mathrm{Trz}}\right), 145.89\left(\mathrm{ArC}_{\mathrm{q}}\right) 145.68 \quad\left(\mathrm{ArC}_{\mathrm{q}}\right)$, $135.45\left(\mathrm{ArC}_{\mathrm{q}}\right), 132.28(\mathrm{ArCH}), 131.45(\mathrm{ArCH}), 129.88$ $\left(\mathrm{ArC}_{\mathrm{q}}\right), 124.78(\mathrm{ArCH}), 124.20(\mathrm{ArCH}), 63.41\left(\mathrm{O}\left(\mathrm{CH}_{2}\right)_{2}\right)$, $29.05\left(\mathrm{CH}\left(\mathrm{CH}_{3}\right)_{2}\right), 28.99\left(\mathrm{CH}\left(\mathrm{CH}_{3}\right)_{2}\right), 26.59\left(\mathrm{CH}\left(\mathrm{CH}_{3}\right)_{2}\right)$, $25.83\left(\mathrm{CH}\left(\mathrm{CH}_{3}\right)_{2}\right), 23.29\left(\mathrm{CH}\left(\mathrm{CH}_{3}\right)_{2}\right), 23.12\left(\mathrm{CH}\left(\mathrm{CH}_{3}\right)_{2}\right)$. HRMS (FIA-ESI): calcd for $\mathrm{C}_{57} \mathrm{H}_{72} \mathrm{~N}_{6} \mathrm{O}_{4} \mathrm{ClRh}_{2}[\mathrm{M}-\mathrm{Cl}-$ $\mathrm{CO}]^{+}$: 1145.3414; found: 1145.3220, $\mathrm{C}_{56} \mathrm{H}_{72} \mathrm{~N}_{6} \mathrm{O}_{3} \mathrm{Cl}_{2} \mathrm{Rh}_{2}[\mathrm{M}$ $-2 \mathrm{CO}]^{+}: 1152.3153$; found: $1152.3556, \mathrm{C}_{56} \mathrm{H}_{72} \mathrm{~N}_{6} \mathrm{O}_{3} \mathrm{ClRh}_{2}$ $[\mathrm{M}-\mathrm{Cl}-2 \mathrm{CO}]^{+}:$1117.3464; found: 1117.3301 . FTIR $\nu_{\mathrm{CO}}$ $\left(\mathrm{CH}_{2} \mathrm{Cl}_{2}\right): 2076,1995 \mathrm{~cm}^{-1}$.

Synthesis of $4 \mathrm{~b}\left[\mathrm{Ir}_{2}(\mathrm{CO})_{4} \mathrm{Cl}_{2}(\mu-\mathrm{COC})\right]$. Complex $4 \mathrm{~b}$ was synthesized in a one-pot synthetic approach, using the metal precursor $[\operatorname{Ir}(\operatorname{cod}) \mathrm{Cl}]_{2}$, followed by 1,5-cyclooctadiene (cod) substitution with $\mathrm{CO}(\mathrm{g})$. An oven-dried Schlenk tube was loaded with $\left[\mathrm{H}_{2}(\mathrm{COC})\right]\left(\mathrm{PF}_{6}\right)_{2}(369 \mathrm{mg}, 0.33 \mathrm{mmol})$, KHMDS (165 mg, $0.83 \mathrm{mmol})$, and $[\operatorname{Ir}(\operatorname{cod}) \mathrm{Cl}]_{2}(222 \mathrm{mg}$, $0.33 \mathrm{mmol}$ ) and submerged in a cold bath at $-78{ }^{\circ} \mathrm{C}$ under stirring. Anhydrous THF (ca. $50 \mathrm{~mL}$ ) was transferred via a cannula to the Schlenk tube under stirring in an inert atmosphere. The reaction was allowed to react for $30 \mathrm{~min}$ before the septum was removed, and the Schlenk was capped for overnight reaction, gradually heating to RT before allowing to reach $\mathrm{RT}$. The reaction mixture turned from yellow-orange to a darker yellow-brown upon overnight reaction. The solvent was removed under reduced pressure, followed by hexane extraction. The hexane fraction was dried and redissolved in anhydrous dichloromethane, after which $\mathrm{CO}(\mathrm{g})$ was bubbled through the solution for $1 \mathrm{~h}$. The product was isolated by evaporating the solvent, extracting compound $\mathbf{4 b}$
$\left[\mathrm{Ir}_{2}(\mathrm{CO})_{4} \mathrm{Cl}_{2}(\mu\right.$-COC $\left.)\right]$ with hexane, and drying the light brown solid overnight $(0.22 \mathrm{~g}, 0.16 \mathrm{mmol}, 48 \%)$.

${ }^{1} \mathrm{H}$ NMR: $\delta_{\mathrm{H}}\left(\mathrm{CDCl}_{3}, 500.13 \mathrm{MHz}\right) 7.57\left(\mathrm{~m}, 4 \mathrm{H}, \mathrm{ArH}_{\mathrm{Dipp}}\right)$, 7.35 (dd, $\left.8 \mathrm{H}, J=7.9,7.8 \mathrm{~Hz} \operatorname{ArH}_{\text {Dipp }}\right), 4.59$ (s, 4H, O $\left.\left(\mathrm{CH}_{2}\right)_{2}\right)$, 2.51 (sept, $\left.4 \mathrm{H}, J=6.7 \mathrm{~Hz}, \mathrm{CH}\left(\mathrm{CH}_{3}\right)_{2}\right), 2.22$ (sept, $4 \mathrm{H}, J=6.7$ $\left.\mathrm{Hz}, \mathrm{CH}\left(\mathrm{CH}_{3}\right)_{2}\right), 1.37\left(\mathrm{~d}, 12 \mathrm{H}, J=6.7 \mathrm{~Hz}, \mathrm{CH}\left(\mathrm{CH}_{3}\right)_{2}\right), 1.20$ $\left(\mathrm{d}, 12 \mathrm{H}, J=6.8 \mathrm{~Hz}, \mathrm{CH}\left(\mathrm{CH}_{3}\right)_{2}\right), 1.09(\mathrm{dd}, 24 \mathrm{H}, J=6.8,6.8$ $\left.\mathrm{Hz}, \mathrm{CH}\left(\mathrm{CH}_{3}\right)_{2}\right) .{ }^{13} \mathrm{C}$ NMR: $\delta_{\mathrm{C}}\left(\mathrm{CDCl}_{3}, 125.31 \mathrm{MHz}\right) \delta$ $181.35\left(\mathrm{Ir}-\mathrm{CO}_{\text {trans carbene }}\right), 170.46\left(\mathrm{C}_{\text {carbene }}\right), 168.62$ ( Ir$\left.\mathrm{CO}_{\text {trans } \mathrm{Cl}}\right), 147.16\left(\mathrm{C}_{\mathrm{q} T \mathrm{Trz}}\right), 145.83\left(\mathrm{ArC}_{\mathrm{q}}\right) 145.62\left(\mathrm{ArC}_{\mathrm{q}}\right)$, $135.11\left(\mathrm{ArC}_{\mathrm{q}}\right), 132.46(\mathrm{ArCH}), 131.59(\mathrm{ArCH}), 129.68$ $\left(\mathrm{ArC}_{\mathrm{q}}\right), 124.90(\mathrm{ArCH}), 124.19(\mathrm{ArCH}), 63.10\left(\mathrm{O}\left(\mathrm{CH}_{2}\right)_{2}\right)$, $29.22\left(\mathrm{CH}\left(\mathrm{CH}_{3}\right)_{2}\right), 29.06\left(\mathrm{CH}\left(\mathrm{CH}_{3}\right)_{2}\right), 26.62\left(\mathrm{CH}\left(\mathrm{CH}_{3}\right)_{2}\right)$, $25.82\left(\mathrm{CH}\left(\mathrm{CH}_{3}\right)_{2}\right), 23.31\left(\mathrm{CH}\left(\mathrm{CH}_{3}\right)_{2}\right), 22.98\left(\mathrm{CH}\left(\mathrm{CH}_{3}\right)_{2}\right)$. HRMS (FIA-ESI): calcd for $\mathrm{C}_{56} \mathrm{H}_{73} \mathrm{~N}_{6} \mathrm{O}_{3} \mathrm{Cl}_{2} \mathrm{Ir}_{2}[\mathrm{M}-2 \mathrm{CO}$ $+\mathrm{H}]^{+}:$1333.4357; found: 1333.3364 and also $\mathrm{C}_{56} \mathrm{H}_{72} \mathrm{~N}_{6} \mathrm{O}_{3} \mathrm{Cl}_{2} \mathrm{Ir}_{2}[\mathrm{M}-2 \mathrm{CO}]^{+}:$1332.4279; found: 1332.3394. FTIR $\nu_{\mathrm{CO}}\left(\mathrm{CH}_{2} \mathrm{Cl}_{2}\right): 2063,1978 \mathrm{~cm}^{-1}$.

Synthesis of $5\left[\mathrm{Ag}_{2} \mathrm{Cl}_{2}(\boldsymbol{\mu}-\mathrm{COC})\right]$. To a Schlenk tube loaded with $\left[\mathrm{H}_{2}(\mathrm{COC})\right]\left(\mathrm{PF}_{6}\right)_{2}(496 \mathrm{mg}, 0.45 \mathrm{mmol}), \mathrm{KCl}(74$ $\mathrm{mg}, 1.11 \mathrm{mmol})$, and $\mathrm{Ag}_{2} \mathrm{O}(206 \mathrm{mg}, 0.89 \mathrm{mmol})$ was added acetonitrile (ca. $50 \mathrm{~mL}$ ) and stirred in a dark environment for 3 days. The reaction mixture was filtered. The filtrate was collected and evaporated to dryness under vacuum to perform a cannula filtration with dichloromethane. After cannula filtration and evaporation of the solvent under reduced pressure, compound $5\left[\mathrm{Ag}_{2} \mathrm{Cl}_{2}(\mu\right.$-COC) $]$ (404 mg, 0.36 mmol, $82 \%)$ was obtained as a gray solid. The product was dried under vacuum at $50{ }^{\circ} \mathrm{C}$ overnight for NMR analysis.

${ }^{1} \mathrm{H}$ NMR: $\delta_{\mathrm{H}}\left(\mathrm{CDCl}_{3}, 500.13 \mathrm{MHz}\right) 7.83(\mathrm{t}, 1 \mathrm{H}, J=6.4 \mathrm{~Hz}$, $\left.\operatorname{ArH}_{\text {Dipp }}\right), 7.67\left(\mathrm{t}, 1 \mathrm{H}, J=8.4 \mathrm{~Hz}, \operatorname{ArH}_{\text {Dipp }}\right), 7.56(\mathrm{dd}, 2 \mathrm{H}, J=$ $6.7 \mathrm{~Hz}, \operatorname{ArH}_{\text {Dipp }}$ ), 7.47 (d, 2H, J = 7.5 Hz, ArH Dipp), 7.39 (t, $1 \mathrm{H}, J=8.1 \mathrm{~Hz}, \operatorname{ArH}_{\text {Dipp }}$ ), 7.32 (d, $4 \mathrm{H}, J=7.9 \mathrm{~Hz}, \operatorname{ArH}_{\text {Dipp }}$ ), $7.21\left(\mathrm{t}, 1 \mathrm{H}, \mathrm{J}=8.4 \mathrm{~Hz}, \operatorname{ArH}_{\text {Dipp }}\right), 4.47\left(\mathrm{~m}, 2 \mathrm{H}, \mathrm{O}-\left(\mathrm{CH}_{2}\right)_{2}\right)$, $4.05\left(\mathrm{~s}, 2 \mathrm{H}, \mathrm{O}-\left(\mathrm{CH}_{2}\right)_{2}\right), 2.23$ (sept, $4 \mathrm{H}, J=5.8 \mathrm{~Hz}$, $\left.\mathrm{CH}\left(\mathrm{CH}_{3}\right)_{2}\right), 2.06$ (sept, 4H, $\left.J=6.8 \mathrm{~Hz}, \mathrm{CH}\left(\mathrm{CH}_{3}\right)_{2}\right), 1.30$ (d, $\left.12 \mathrm{H}, J=6.8 \mathrm{~Hz}, \mathrm{CH}\left(\mathrm{CH}_{3}\right)_{2}\right), 1.23\left(\mathrm{~m}, 6 \mathrm{H}, \mathrm{CH}\left(\mathrm{CH}_{3}\right)_{2}\right), 1.14$ $\left(\mathrm{d}, 12 \mathrm{H}, J=6.8 \mathrm{~Hz}, \mathrm{CH}\left(\mathrm{CH}_{3}\right)_{2}\right), 1.08(\mathrm{~d}, 12 \mathrm{H}, J=6.7 \mathrm{~Hz}$, $\left.\mathrm{CH}\left(\mathrm{CH}_{3}\right)_{2}\right), 1.04\left(\mathrm{~d}, 6 \mathrm{H}, J=6.5 \mathrm{~Hz}, \mathrm{CH}\left(\mathrm{CH}_{3}\right)_{2}\right) .{ }^{13} \mathrm{C} \mathrm{NMR}$ : $\delta_{\mathrm{C}}\left(\mathrm{CDCl}_{3}, 125.31 \mathrm{MHz}\right) 172.51\left(\mathrm{C}_{\text {carbene }}\right), 160.12\left(\mathrm{C}_{\mathrm{q} T \mathrm{Tz}}\right)$, $145.22\left(\operatorname{ArC}_{\mathrm{q}}\right), 145.02\left(\operatorname{ArC}_{\mathrm{q}}\right), 144.97\left(\mathrm{ArC}_{\mathrm{q}}\right), 135.35\left(\mathrm{ArC}_{\mathrm{q}}\right)$, $135.29\left(\mathrm{ArC}_{\mathrm{q}}\right), 133.90(\mathrm{ArCH}), 131.81(\mathrm{ArCH}), 129.16$ $\left(\mathrm{ArC}_{\mathrm{q}}\right) 125.55(\mathrm{ArCH}), 125.06(\mathrm{ArCH}), 124.97(\mathrm{ArCH})$, $124.54(\mathrm{ArCH}), 63.54\left(\mathrm{O}-\left(\mathrm{CH}_{2}\right)_{2}\right), 29.50\left(\mathrm{CH}\left(\mathrm{CH}_{3}\right)_{2}\right)$, $29.22\left(\mathrm{CH}\left(\mathrm{CH}_{3}\right)_{2}\right), 28.99\left(\mathrm{CH}\left(\mathrm{CH}_{3}\right)_{2}\right), 28.73\left(\mathrm{CH}\left(\mathrm{CH}_{3}\right)_{2}\right)$, $25.97\left(\mathrm{CH}\left(\mathrm{CH}_{3}\right)_{2}\right), 25.91\left(\mathrm{CH}\left(\mathrm{CH}_{3}\right)_{2}\right), 25.77\left(\mathrm{CH}\left(\mathrm{CH}_{3}\right)_{2}\right)$, $25.70\left(\mathrm{CH}\left(\mathrm{CH}_{3}\right)_{2}\right), 24.62\left(\mathrm{CH}\left(\mathrm{CH}_{3}\right)_{2}\right), 24.56\left(\mathrm{CH}\left(\mathrm{CH}_{3}\right)_{2}\right)$, $24.43\left(\mathrm{CH}\left(\mathrm{CH}_{3}\right)_{2}\right), 22.80\left(\mathrm{CH}\left(\mathrm{CH}_{3}\right)_{2}\right)$. HRMS (FIA-ESI): calcd for $\left[\mathrm{C}_{54} \mathrm{H}_{75} \mathrm{~N}_{6} \mathrm{OCl}_{2} \mathrm{Ag}_{2}\right] ; 1107.3481$; found: 1107.3492 .

Synthesis of $6\left[R_{2}(\operatorname{cod})_{2}(\mu-C N C)\right]\left(P_{6}\right)$. An oven-dried Schlenk tube was loaded with $\left[\mathrm{H}_{2}\left(\mathbf{C}^{\mathrm{H}} \mathbf{N C}\right)\right]\left(\mathrm{PF}_{6}\right)(206 \mathrm{mg}$, $0.19 \mathrm{mmol}), \mathrm{KO}^{t} \mathrm{Bu}(72 \mathrm{mg}, 0.65 \mathrm{mmol})$, and $[\mathrm{Rh}(\mathrm{cod}) \mathrm{Cl}]_{2}$ $(82 \mathrm{mg}, 0.17 \mathrm{mmol})$ and submerged in a cold bath at $-78^{\circ} \mathrm{C}$ under stirring. Anhydrous THF (ca. $50 \mathrm{~mL}$ ) was transferred via a cannula to the Schlenk tube under stirring for $30 \mathrm{~min}$ in an inert atmosphere before the septum was removed, and the Schlenk tube was sealed. The reaction mixture was stirred overnight while gradually warming to RT. The reaction mixture turned from light yellow to light brown. After solvent evaporation, the residue was washed with hexanes, followed by DEE. Extraction with dichloromethane afforded compound 6 $\left[\mathrm{Rh}_{2}(\mathrm{cod})_{2}(\mu-\mathrm{CNC})\right]\left(\mathrm{PF}_{6}\right)(150 \mathrm{mg}, 0.11 \mathrm{mmol}, 58 \%)$ as a deep orange solid. Crystallization from a toluene/dichloro- 
methane mixture yielded single crystals suitable for XRD analysis.

${ }^{1} \mathrm{H}$ NMR: $\delta_{\mathrm{H}}\left(\mathrm{CD}_{2} \mathrm{Cl}_{2}, 400.21 \mathrm{MHz}\right) 7.54(\mathrm{~m}, 4 \mathrm{H}$, $\left.\operatorname{ArH}_{\text {Dipp }}\right), 7.34\left(\mathrm{t}, 4 \mathrm{H}, J=7.6 \mathrm{~Hz}, \operatorname{ArH}_{\text {Dipp }}\right), 7.27(\mathrm{t}, 4 \mathrm{H}, J=$ $\left.8.9 \mathrm{~Hz}, \operatorname{ArH}_{\text {Dipp }}\right), 6.28$ (d, $2 \mathrm{H}, J=6.5 \mathrm{~Hz}$, cod-CH), 4.76 (d, $\left.2 \mathrm{H}, J=18.1 \mathrm{~Hz}, \mathrm{~N}\left(\mathrm{CH}_{2}\right)_{2}\right), 3.74(\mathrm{~s}, 1 \mathrm{H}$, cod- $\mathrm{CH}), 3.68$ (d, $\left.2 \mathrm{H}, J=12.4 \mathrm{~Hz}, \mathrm{~N}\left(\mathrm{CH}_{2}\right)_{2}\right), 3.53$ (br s, $2 \mathrm{H}$, cod-CH), 3.45 (br s, $2 \mathrm{H}$, cod- $\mathrm{CH}), 2.46\left(\mathrm{~m}, 4 \mathrm{H}, \mathrm{CH}\left(\mathrm{CH}_{3}\right)_{2}\right), 2.32$ (br s, $2 \mathrm{H}$, cod- $\left.\mathrm{CH}_{2}\right), 2.13\left(\mathrm{~m}, 12 \mathrm{H}, \mathrm{CH}\left(\mathrm{CH}_{3}\right)[4 \mathrm{H}]\right.$, cod- $\left.\mathrm{CH}_{2}[8 \mathrm{H}]\right)$, $1.76\left(\mathrm{~m}, 2 \mathrm{H}\right.$, cod- $\left.\mathrm{CH}_{2}\right), 1.53\left(\mathrm{br} \mathrm{s}, 3 \mathrm{H}\right.$, cod- $\left.\mathrm{CH}_{2}\right), 1.36-0.97$ (overlapping d, $49 \mathrm{H}, J=5.5 \mathrm{~Hz}, \mathrm{CH}\left(\mathrm{CH}_{3}\right)[48 \mathrm{H}]$, underlying cod-CH $\left.\mathrm{CH}_{2}[1 \mathrm{H}]\right) .{ }^{13} \mathrm{C}$ NMR: $\delta_{\mathrm{C}}\left(\mathrm{CD}_{2} \mathrm{Cl}_{2}, 100.64 \mathrm{MHz}\right) 161.54$ $\left(\mathrm{C}_{\text {carbene }}\right), 156.29\left(\mathrm{C}_{\mathrm{q} T r z}\right), 145.27\left(\operatorname{ArC}_{\mathrm{q}}\right), 145.12\left(\mathrm{ArC}_{\mathrm{q}}\right)$, $144.78\left(\mathrm{ArC}_{\mathrm{q}}\right), 144.71\left(\mathrm{ArC}_{\mathrm{q}}\right), 133.78\left(\mathrm{ArC}_{\mathrm{q}}\right), 132.29$ $(\mathrm{ArCH}), 131.67(\mathrm{ArCH}), 129.69\left(\mathrm{ArC}_{\mathrm{q}}\right), 125.27(\mathrm{ArCH})$, $125.20(\mathrm{ArCH}), 124.12(\mathrm{ArCH}), 123.95(\mathrm{ArCH}), 97.02(\mathrm{~d}, J$ $=9.4 \mathrm{~Hz}, \operatorname{cod}-\mathrm{CH}), 89.01(\mathrm{~d}, J=6.9 \mathrm{~Hz}, \operatorname{cod}-\mathrm{CH}), 68.12(\mathrm{~d}, J$ $=11.8 \mathrm{~Hz}$, cod-CH), $67.83(\mathrm{~d}, J=13.0 \mathrm{~Hz}$, cod-CH), 61.99 $\left(\mathrm{N}\left(\mathrm{CH}_{2}\right)_{2}\right), 35.01\left(\operatorname{cod}-\mathrm{CH}_{2}\right), 32.27\left(\operatorname{cod}-\mathrm{CH}_{2}\right), 29.35$ $\left(\mathrm{CH}\left(\mathrm{CH}_{3}\right)_{2}\right), 29.20\left(\mathrm{CH}\left(\mathrm{CH}_{3}\right)_{2}\right), 29.03\left(\mathrm{CH}\left(\mathrm{CH}_{3}\right)_{2}\right), 28.85$ $\left(\mathrm{CH}\left(\mathrm{CH}_{3}\right)_{2}\right), 28.31$ (cod- $\left.\mathrm{CH}_{2}\right), 28.01\left(\right.$ cod- $\left.\mathrm{CH}_{2}\right), 26.81$ $\left(\mathrm{CH}\left(\mathrm{CH}_{3}\right)_{2}\right), 26.63\left(\mathrm{CH}\left(\mathrm{CH}_{3}\right)_{2}\right), 26.45\left(\mathrm{CH}\left(\mathrm{CH}_{3}\right)_{2}\right), 25.93$ $\left(\mathrm{CH}\left(\mathrm{CH}_{3}\right)_{2}\right), 24.04\left(\mathrm{CH}\left(\mathrm{CH}_{3}\right)_{2}\right), 23.48\left(\mathrm{CH}\left(\mathrm{CH}_{3}\right)_{2}\right), 22.59$ $\left(\mathrm{CH}\left(\mathrm{CH}_{3}\right)_{2}\right), 22.17\left(\mathrm{CH}\left(\mathrm{CH}_{3}\right)_{2}\right) .{ }^{19} \mathrm{~F}$ NMR: $\delta_{\mathrm{F}}\left(\mathrm{CD}_{2} \mathrm{Cl}_{2}\right.$, $376.57 \mathrm{MHz})-73.28$ (d, $\left.J=711.0 \mathrm{~Hz}, \mathrm{PF}_{6}\right) .{ }^{31} \mathrm{P}$ NMR: $\delta_{\mathrm{P}}$ $\left(\mathrm{CD}_{2} \mathrm{Cl}_{2}, 162.01 \mathrm{MHz}\right)-144.71$ (sept, $J=710.9 \mathrm{~Hz}, \mathrm{PF}_{6}$ ). HRMS (FIA-ESI): calcd for $\left[\mathrm{C}_{70} \mathrm{H}_{96} \mathrm{~N}_{7} \mathrm{Rh}_{2}\right]^{+}\left[\mathrm{M}-\mathrm{PF}_{6}\right]$ : 1240.5837; found: 1240.4195 .

Synthesis of $7 \mathrm{a}[\mathrm{Ir}(\mathrm{COd})(\mathrm{HCNC})]\left(\mathrm{PF}_{6}\right)$. An oven-dried Schlenk tube was loaded with $\left[\mathrm{H}_{2}\left(\mathrm{C}^{\mathrm{H}} \mathrm{NC}\right)\right]\left(\mathrm{PF}_{6}\right)(179 \mathrm{mg}$, $0.16 \mathrm{mmol}), \mathrm{KO}^{t} \mathrm{Bu}(72 \mathrm{mg}, 0.64 \mathrm{mmol})$, and $[\operatorname{Ir}(\operatorname{cod}) \mathrm{Cl}]_{2}$ $(129 \mathrm{mg}, 0.19 \mathrm{mmol})$ and submerged in a cold bath at $-78{ }^{\circ} \mathrm{C}$ under stirring. Anhydrous THF (ca. $50 \mathrm{~mL}$ ) was transferred via a cannula to the Schlenk tube under stirring for $30 \mathrm{~min}$ in an inert atmosphere before the septum was removed, and the Schlenk tube was sealed. The reaction mixture was stirred overnight under gradual warming to RT. The reaction mixture turned from bright orange to deeper red-orange. After solvent evaporation, the residue was washed with hexanes, followed by diethyl ether. Extraction with dichloromethane afforded compound $7 \mathbf{a}[\operatorname{Ir}(\mathrm{cod})(\mathrm{HCNC})]\left(\mathrm{PF}_{6}\right)(124 \mathrm{mg}, 0.09 \mathrm{mmol}$, $62 \%)$ as an orange solid.

${ }^{1} \mathrm{H}$ NMR: $\delta_{\mathrm{H}}\left(\mathrm{CD}_{2} \mathrm{Cl}_{2}, 500.13 \mathrm{MHz}\right) 8.54\left(\mathrm{~s}, 1 \mathrm{H}, \mathrm{CH}_{\mathrm{Trz}}\right)$, $7.71\left(\mathrm{dt}, 2 \mathrm{H}, J=7.8 \mathrm{~Hz}, \operatorname{ArH}_{\text {Dipp }}\right), 7.60(\mathrm{t}, 1 \mathrm{H}, J=7.8 \mathrm{~Hz}$, $\left.\operatorname{ArH}_{\text {Dipp }}\right), 7.54$ (t, 1H, J = 7.8 Hz, ArH $\left.\operatorname{Dipp}_{\text {) }}\right), 7.47$ (d, 2H, J = 7.8 $\left.\mathrm{Hz}, \operatorname{ArH}_{\text {Dipp }}\right), 7.43$ (t, 2H, J = 8.0 Hz, ArH $\left.{ }_{\text {Dipp }}\right), 7.39$ (d, 2H, $J$ $\left.=7.9 \mathrm{~Hz}, \operatorname{ArH}_{\text {Dipp }}\right), 7.29\left(\mathrm{~d}, 2 \mathrm{H}, J=7.8 \mathrm{~Hz}, \operatorname{ArH}_{\text {Dipp }}\right), 4.42(\mathrm{~s}$, $\left.2 \mathrm{H}, \mathrm{N}\left(\mathrm{CH}_{2}\right)_{2}\right), 3.72\left(\mathrm{~s}, 2 \mathrm{H}, \mathrm{N}\left(\mathrm{CH}_{2}\right)_{2}\right), 3.22$ (br s, $2 \mathrm{H}, J=7.8$, cod-CH), 2.55 (br s, $2 \mathrm{H}$, cod-CH), 2.46 (hept, $2 \mathrm{H}, J=6.7 \mathrm{~Hz}$, $\left.\mathrm{CH}\left(\mathrm{CH}_{3}\right)_{2}\right), 2.32$ (hept, $\left.2 \mathrm{H}, J=6.8 \mathrm{~Hz}, \mathrm{CH}\left(\mathrm{CH}_{3}\right)_{2}\right), 2.09$ (hept, $\left.2 \mathrm{H}, J=6.7 \mathrm{~Hz}, \mathrm{CH}\left(\mathrm{CH}_{3}\right)_{2}\right), 1.98$ (hept, $2 \mathrm{H}, J=6.7 \mathrm{~Hz}$, $\left.\mathrm{CH}\left(\mathrm{CH}_{3}\right)_{2}\right), 1.79$ (br t, $3 \mathrm{H}, \mathrm{J}=11.3 \mathrm{~Hz}$, cod- $\left.\mathrm{CH}_{2}\right), 1.54$ (br s, $1 \mathrm{H}$, cod- $\left.\mathrm{CH}_{2}\right), 1.42\left(\mathrm{~m}, 4 \mathrm{H}\right.$, cod- $\left.\mathrm{CH}_{2}\right), 1.33(\mathrm{dd}, 10 \mathrm{H}, \mathrm{J}=6.7$ $\left.\mathrm{Hz}, \mathrm{CH}\left(\mathrm{CH}_{3}\right)\right), 1.28\left(\mathrm{dd}, 3 \mathrm{H}, \mathrm{J}=6.6 \mathrm{~Hz}, \mathrm{CH}\left(\mathrm{CH}_{3}\right)\right), 1.22(\mathrm{~d}$, $\left.6 \mathrm{H}, J=6.8 \mathrm{~Hz}, \mathrm{CH}\left(\mathrm{CH}_{3}\right)\right), 1.15\left(\mathrm{~m}, 17 \mathrm{H}, \mathrm{CH}\left(\mathrm{CH}_{3}\right)\right), 1.10$ $\left(\mathrm{d}, 6 \mathrm{H}, J=6.8 \mathrm{~Hz}, \mathrm{CH}\left(\mathrm{CH}_{3}\right)\right), 1.07(\mathrm{~d}, 6 \mathrm{H}, J=6.9 \mathrm{~Hz}$, $\left.\mathrm{CH}\left(\mathrm{CH}_{3}\right)\right){ }^{13} \mathrm{C}$ NMR: $\delta_{\mathrm{C}}\left(\mathrm{CD}_{2} \mathrm{Cl}_{2}, 125.31 \mathrm{MHz}\right) 166.45$ $\left(\mathrm{C}_{\text {carbene }}\right), 162.07\left(\mathrm{C}_{\mathrm{q} \text { Trz-Ir }}\right), 150.23\left(\mathrm{C}_{\mathrm{q} \text { Trz-H }}\right), 146.31\left(\mathrm{ArC}_{\mathrm{q}}\right)$, $146.29\left(\mathrm{ArC}_{\mathrm{q}}\right), 146.18\left(\mathrm{ArC}_{\mathrm{q}}\right), 145.80\left(\mathrm{ArC}_{\mathrm{q}}\right), 145.71\left(\mathrm{ArC}_{\mathrm{q}}\right)$, $145.60\left(\operatorname{ArC}_{\mathrm{q}}\right), 145.47\left(\mathrm{ArC}_{\mathrm{q}}\right), 135.14\left(\mathrm{ArC}_{\mathrm{q}}\right), 134.13$ $(\mathrm{ArCH}), 133.98(\mathrm{ArCH}), 133.59(\mathrm{ArCH}), 133.21(\mathrm{ArCH})$, 132.78 ( $\mathrm{ArCH}), 132.33(\mathrm{Trz}-\mathrm{CH}), 131.94(\mathrm{ArCH}), 130.99$ $\left(\operatorname{ArC}_{\mathrm{q}}\right), 130.84\left(\operatorname{ArC}_{\mathrm{q}}\right), 128.93\left(\operatorname{ArC}_{\mathrm{q}}\right), 128.65\left(\operatorname{ArC}_{\mathrm{q}}\right), 125.82$
$(\mathrm{ArCH}), 125.64(\mathrm{ArCH}), 125.57(\mathrm{ArCH}), 125.46(\mathrm{ArCH})$, $125.32(\mathrm{ArCH}), 124.27(\mathrm{ArCH}), 75.45(\mathrm{cod}-\mathrm{CH}), 56.68$ $\left(\mathrm{N}\left(\mathrm{CH}_{2}\right)_{2}\right), 49.99\left(\mathrm{~N}\left(\mathrm{CH}_{2}\right)_{2}\right), 46.33($ cod- $\mathrm{CH}), 33.48$ (cod$\left.\mathrm{CH}_{2}\right), 31.17\left(\mathrm{CH}\left(\mathrm{CH}_{3}\right)_{2}\right), 30.81\left(\operatorname{cod}-\mathrm{CH}_{2}\right), 30.23(\mathrm{CH}-$ $\left.\left(\mathrm{CH}_{3}\right)_{2}\right), \quad 30.09\left(\mathrm{CH}\left(\mathrm{CH}_{3}\right)_{2}\right), 29.88\left(\mathrm{CH}\left(\mathrm{CH}_{3}\right)_{2}\right), 29.72$ $\left(\mathrm{CH}\left(\mathrm{CH}_{3}\right)_{2}\right), 29.60\left(\mathrm{CH}\left(\mathrm{CH}_{3}\right)_{2}\right), 29,43\left(\mathrm{CH}\left(\mathrm{CH}_{3}\right)_{2}\right), 29.24$ $\left(\mathrm{CH}\left(\mathrm{CH}_{3}\right)_{2}\right), 26.61\left(\mathrm{CH}\left(\mathrm{CH}_{3}\right)_{2}\right), 25.70\left(\mathrm{CH}\left(\mathrm{CH}_{3}\right)_{2}\right), 25.64$ $\left(\mathrm{CH}\left(\mathrm{CH}_{3}\right)_{2}\right), 25.57\left(\mathrm{CH}\left(\mathrm{CH}_{3}\right)_{2}\right), 25.26\left(\mathrm{CH}\left(\mathrm{CH}_{3}\right)_{2}\right), 25.22$ $\left(\mathrm{CH}\left(\mathrm{CH}_{3}\right)_{2}\right), 24.87\left(\mathrm{CH}\left(\mathrm{CH}_{3}\right)_{2}\right), 24.82\left(\mathrm{CH}\left(\mathrm{CH}_{3}\right)_{2}\right), 24.38$ $\left(\mathrm{CH}\left(\mathrm{CH}_{3}\right)_{2}\right), 24.08\left(\mathrm{CH}\left(\mathrm{CH}_{3}\right)_{2}\right), 24.02\left(\mathrm{CH}\left(\mathrm{CH}_{3}\right)_{2}\right), 23.80$ $\left(\mathrm{CH}\left(\mathrm{CH}_{3}\right)_{2}\right), 23.66\left(\mathrm{CH}\left(\mathrm{CH}_{3}\right)_{2}\right), 23.41\left(\mathrm{CH}\left(\mathrm{CH}_{3}\right)_{2}\right), 23.16$ $\left(\mathrm{CH}\left(\mathrm{CH}_{3}\right)_{2}\right), 22.55\left(\mathrm{CH}\left(\mathrm{CH}_{3}\right)_{2}\right){ }^{19} \mathrm{~F}$ NMR: $\delta_{\mathrm{F}}\left(\mathrm{CD}_{2} \mathrm{Cl}_{2}\right.$, $470.59 \mathrm{MHz})-73.07\left(\mathrm{~d}, J=711.1 \mathrm{~Hz}, \mathrm{PF}_{6}\right) .{ }^{31} \mathrm{P}$ NMR: $\delta_{\mathrm{P}}$ $\left(\mathrm{CD}_{2} \mathrm{Cl}_{2}, 202.46 \mathrm{MHz}\right)-144.50$ (sept, $J=711.0 \mathrm{~Hz}, \mathrm{PF}_{6}$ ). HRMS (FIA-ESI): calcd for $\left[\mathrm{C}_{62} \mathrm{H}_{85} \mathrm{~N}_{7} \mathrm{Ir}\right]^{+}\left[\mathrm{M}-\mathrm{PF}_{6}\right]$ : 1120.6495; found: 1120.6492 .

Synthesis of $7 \mathrm{~b}\left[\operatorname{Ir}(\mathrm{CO})_{2}(\mathrm{HCNC})\right]\left(\mathrm{PF}_{6}\right)$. Compound $7 \mathrm{~b}$ was obtained by substitution of the 1,5-cyclooctadiene ligand (cod) of $7 \mathbf{a}[\operatorname{Ir}(\operatorname{cod})(\mathrm{HCNC})]\left(\mathrm{PF}_{6}\right)$. A dichloromethane solution of compound $7 \mathrm{a}(124 \mathrm{mg}, 0.09 \mathrm{mmol})$ was treated with $\mathrm{CO}(\mathrm{g})$ for $1 \mathrm{~h}$, resulting in no observable color change. After solvent removal, product $7 \mathbf{b}\left[\operatorname{Ir}(\mathrm{CO})_{2}(\mathrm{HCNC})\right]\left(\mathrm{PF}_{6}\right)$ $(118 \mathrm{~g}, 0.09 \mathrm{mmol}, 100 \%)$ was obtained as a dark orangebrown solid. The product was dried under vacuum at $50{ }^{\circ} \mathrm{C}$ overnight for NMR analysis. Single crystals suitable for XRD analysis were obtained from dichloromethane/hexane by slow vapor diffusion.

${ }^{1} \mathrm{H}$ NMR: $\delta_{\mathrm{H}}\left(\mathrm{CD}_{2} \mathrm{Cl}_{2}, 500.13 \mathrm{MHz}\right) 8.75\left(\mathrm{~s}, 1 \mathrm{H}, \mathrm{CH}_{\mathrm{Trz}}\right)$, $7.72\left(\mathrm{dt}, 2 \mathrm{H}, J=7.8 \mathrm{~Hz}, \operatorname{ArH}_{\text {Dipp }}\right), 7.65(\mathrm{t}, 1 \mathrm{H}, J=7.6 \mathrm{~Hz}$, $\left.\operatorname{ArH}_{\text {Dipp }}\right), 7.59$ (t, $1 \mathrm{H}, J=7.6 \mathrm{~Hz}, \operatorname{ArH}_{\text {Dipp }}$ ), 7.47 (d, 2H, $J=8.0$ $\mathrm{Hz}, \operatorname{ArH}_{\text {Dipp }}$ ), 7.43 (dd, $\left.4 \mathrm{H}, J=7.9 \mathrm{~Hz}, \operatorname{ArH}_{\text {Dipp }}\right), 7.37$ (d, 2H, $\left.J=7.8 \mathrm{~Hz}, \operatorname{ArH}_{\text {Dipp }}\right), 5.01\left(\mathrm{~s}, 2 \mathrm{H}, \mathrm{N}\left(\mathrm{CH}_{2}\right)_{2}\right), 3.95(\mathrm{~s}, 2 \mathrm{H}$, $\left.\mathrm{N}\left(\mathrm{CH}_{2}\right)_{2}\right), 2.35$ (hept, $\left.2 \mathrm{H}, J=6.7 \mathrm{~Hz}, \mathrm{CH}\left(\mathrm{CH}_{3}\right)_{2}\right), 2.28$ (hept, $\left.2 \mathrm{H}, J=6.7 \mathrm{~Hz}, \mathrm{CH}\left(\mathrm{CH}_{3}\right)_{2}\right), 2.13$ (hept, $2 \mathrm{H}, J=6.5 \mathrm{~Hz}$, $\left.\mathrm{CH}\left(\mathrm{CH}_{3}\right)_{2}\right), 2.05$ (hept, $\left.2 \mathrm{H}, \mathrm{J}=6.7 \mathrm{~Hz}, \mathrm{CH}\left(\mathrm{CH}_{3}\right)_{2}\right), 1.33$ $\left(\mathrm{dd}, 12 \mathrm{H}, J=8.3 \mathrm{~Hz}, \mathrm{CH}\left(\mathrm{CH}_{3}\right)\right), 1.29(\mathrm{~d}, 2 \mathrm{H}, J=6.7 \mathrm{~Hz}$, $\left.\mathrm{CH}\left(\mathrm{CH}_{3}\right)\right), 1.26\left(\mathrm{~d}, 4 \mathrm{H}, J=6.8 \mathrm{~Hz}, \mathrm{CH}\left(\mathrm{CH}_{3}\right)\right), 1.23(\mathrm{~d}, 2 \mathrm{H}, J$ $\left.=7.0 \mathrm{~Hz}, \mathrm{CH}\left(\mathrm{CH}_{3}\right)\right), 1.18\left(\mathrm{dd}, 12 \mathrm{H}, \mathrm{J}=5.7 \mathrm{~Hz}, \mathrm{CH}\left(\mathrm{CH}_{3}\right)\right)$, $1.15\left(\mathrm{~d}, 8 \mathrm{H}, J=6.9 \mathrm{~Hz}, \mathrm{CH}\left(\mathrm{CH}_{3}\right)\right), 1.12(\mathrm{~d}, 6 \mathrm{H}, J=6.8 \mathrm{~Hz}$, $\left.\mathrm{CH}\left(\mathrm{CH}_{3}\right)\right), 1.08\left(\mathrm{~d}, 2 \mathrm{H}, J=7.2 \mathrm{~Hz}, \mathrm{CH}\left(\mathrm{CH}_{3}\right)\right){ }^{13} \mathrm{C} \mathrm{NMR}: \delta_{\mathrm{C}}$ $\left(\mathrm{CD}_{2} \mathrm{Cl}_{2}, 125.31 \mathrm{MHz}\right)$ 186.55.45 ( $\left.\mathrm{Ir}-\mathrm{CO}_{\text {trans carbene }}\right), 178.85$ $\left(\mathrm{Ir}-\mathrm{CO}_{\text {trans N }}\right), 174.07\left(\mathrm{C}_{\text {carbene }}\right), 161.97\left(\mathrm{C}_{\mathrm{q} \text { Trz-Ir }}\right), 155.28$ $\left(\mathrm{C}_{\mathrm{q} \operatorname{Trz}-\mathrm{H}}\right), 149.36\left(\mathrm{ArC}_{\mathrm{q}}\right), 145.99\left(\mathrm{ArC}_{\mathrm{q}}\right), 145.92\left(\mathrm{ArC}_{\mathrm{q}}\right)$, $145.52\left(\operatorname{ArC}_{\mathrm{q}}\right), 145.42\left(\operatorname{ArC}_{\mathrm{q}}\right), 135.29\left(\operatorname{ArC}_{\mathrm{q}}\right), 134.44\left(\operatorname{ArC}_{\mathrm{q}}\right)$, $134.09(\mathrm{ArCH}), 134.02(\mathrm{ArCH}), 133.96(\mathrm{ArCH}), 133.58$ $(\mathrm{ArCH}), 133.18(\mathrm{ArCH}), 132.95\left(\mathrm{ArC}_{\mathrm{q}}\right), 132.55(\mathrm{ArCH})$, $132.30(\mathrm{Trz}-\mathrm{CH}), 131.57\left(\mathrm{ArC}_{\mathrm{q}}\right), 130.80\left(\mathrm{ArC}_{\mathrm{q}}\right), 130.65$ $\left(\mathrm{ArC}_{\mathrm{q}}\right), 129.02\left(\mathrm{ArC}_{\mathrm{q}}\right), 126.11(\mathrm{ArCH}), 125.81(\mathrm{ArCH})$, $125.58(\mathrm{ArCH}), 125.44(\mathrm{ArCH}), 125.32(\mathrm{ArCH}), 124.81$ $(\mathrm{ArCH}), 58.55\left(\mathrm{~N}\left(\mathrm{CH}_{2}\right)_{2}\right), 55.66\left(\mathrm{~N}\left(\mathrm{CH}_{2}\right)_{2}\right), 30.23(\mathrm{CH}-$ $\left.\left(\mathrm{CH}_{3}\right)_{2}\right), 30.04\left(\mathrm{CH}\left(\mathrm{CH}_{3}\right)_{2}\right), 29.91\left(\mathrm{CH}\left(\mathrm{CH}_{3}\right)_{2}\right), 29.84$ $\left(\mathrm{CH}\left(\mathrm{CH}_{3}\right)_{2}\right), 29.77\left(\mathrm{CH}\left(\mathrm{CH}_{3}\right)_{2}\right), 29.71\left(\mathrm{CH}\left(\mathrm{CH}_{3}\right)_{2}\right), 29.63$ $\left(\mathrm{CH}\left(\mathrm{CH}_{3}\right)_{2}\right), 29.44\left(\mathrm{CH}\left(\mathrm{CH}_{3}\right)_{2}\right), 25.89\left(\mathrm{CH}\left(\mathrm{CH}_{3}\right)_{2}\right), 25.70$ $\left(\mathrm{CH}\left(\mathrm{CH}_{3}\right)_{2}\right), 25.64\left(\mathrm{CH}\left(\mathrm{CH}_{3}\right)_{2}\right), 25.52\left(\mathrm{CH}\left(\mathrm{CH}_{3}\right)_{2}\right), 25.22$ $\left(\mathrm{CH}\left(\mathrm{CH}_{3}\right)_{2}\right), 25.14\left(\mathrm{CH}\left(\mathrm{CH}_{3}\right)_{2}\right), 25.10\left(\mathrm{CH}\left(\mathrm{CH}_{3}\right)_{2}\right), 24.87$ $\left(\mathrm{CH}\left(\mathrm{CH}_{3}\right)_{2}\right), 24.60\left(\mathrm{CH}\left(\mathrm{CH}_{3}\right)_{2}\right), 24.43\left(\mathrm{CH}\left(\mathrm{CH}_{3}\right)_{2}\right), 24.12$ $\left(\mathrm{CH}\left(\mathrm{CH}_{3}\right)_{2}\right), 24.04\left(\mathrm{CH}\left(\mathrm{CH}_{3}\right)_{2}\right), 23.81\left(\mathrm{CH}\left(\mathrm{CH}_{3}\right)_{2}\right), 23.65$ $\left(\mathrm{CH}\left(\mathrm{CH}_{3}\right)_{2}\right), 23.16\left(\mathrm{CH}\left(\mathrm{CH}_{3}\right)_{2}\right), 23.10\left(\mathrm{CH}\left(\mathrm{CH}_{3}\right)_{2}\right) .{ }^{19} \mathrm{~F}$ NMR: $\delta_{\mathrm{F}}\left(\mathrm{CD}_{2} \mathrm{Cl}_{2}, 470.59 \mathrm{MHz}\right)-70.86(\mathrm{~d}, J=711.4 \mathrm{~Hz}$, PF $\left.{ }_{6}\right) .{ }^{31}$ P NMR: $\delta_{\mathrm{P}}\left(\mathrm{CD}_{2} \mathrm{Cl}_{2}, 202.46 \mathrm{MHz}\right)-143.44$ (sept, $J=$ $711.3 \mathrm{~Hz}, \mathrm{PF}_{6}$ ). HRMS (FIA-ESI): calcd for $\left[\mathrm{C}_{56} \mathrm{H}_{73} \mathrm{~N}_{7} \mathrm{O}_{2} \mathrm{Ir}\right]^{+}$ $\left[\mathrm{M}-\mathrm{PF}_{6}\right]$ : 1068.5454; found: 1068.5450. FTIR $\nu_{\mathrm{CO}}$ $\left(\mathrm{CH}_{2} \mathrm{Cl}_{2}\right): 2035,1964 \mathrm{~cm}^{-1}$. 
Synthesis of $8 \mathrm{a}\left[\mathrm{Rh}_{2}(\mathrm{CO})_{3} \mathrm{Cl}(\mu-\mathrm{CNC})\right]$. Addition of THF (ca. $50 \mathrm{~mL}$ ) at $-78{ }^{\circ} \mathrm{C}$ to a Schlenk tube loaded with $\left[\mathrm{H}_{2}\left(\mathbf{C}^{\mathrm{H}} \mathbf{N C}\right)\right]\left(\mathrm{PF}_{6}\right)(208 \mathrm{mg}, 0.19 \mathrm{mmol}), \mathrm{KO}^{t} \mathrm{Bu}(67 \mathrm{mg}$, $0.60 \mathrm{mmol})$, and $\left[\mathrm{Rh}(\mathrm{CO})_{2} \mathrm{Cl}\right]_{2}(65 \mathrm{mg}, 0.17 \mathrm{mmol})$ was followed by stirring the reaction mixture for $30 \mathrm{~min}$ at low temperature, whereafter the septum was removed and the reaction vessel was sealed. The reaction mixture was stirred overnight while warming up to RT. The reaction mixture turned from orange-brown to yellow-brown upon overnight reaction. The solvent was evaporated and the reaction mixture was washed with hexane. Cannula extraction with diethyl ether, followed by extraction with dichloromethane ensued. Both fractions were evaporated and combined to afford compound 8a $\left[\mathrm{Rh}_{2}(\mathrm{CO})_{3} \mathrm{Cl}(\mu\right.$-CNC $\left.)\right]$ as a yellow solid $(165 \mathrm{mg}, 0.14$ mmol, 77\%). Crystallization from toluene yielded single crystals suitable for XRD analysis.

${ }^{1} \mathrm{H}$ NMR: $\delta_{\mathrm{H}}\left(\mathrm{C}_{6} \mathrm{D}_{6}, 400.21 \mathrm{MHz}\right) 7.16\left(\mathrm{~m}, 6 \mathrm{H}, \mathrm{ArH}_{\text {Dipp }}\right)$, 7.09 (dd, $\left.2 \mathrm{H}, J=7.6,7.5 \mathrm{~Hz}, \mathrm{ArH}_{\text {Dipp }}\right), 7.06$ (dd, $2 \mathrm{H}, J=7.4$, $\left.7.5 \mathrm{~Hz}, \operatorname{ArH}_{\text {Dipp }}\right), 6.95$ (dd, $\left.2 \mathrm{H}, J=7.6,7.6 \mathrm{~Hz}, \operatorname{ArH}_{\text {Dipp }}\right), 5.29$ $\left(\mathrm{d}, 1 \mathrm{H}, J=2.2 \mathrm{~Hz}, \mathrm{~N}\left(\mathrm{CH}_{2}\right)_{2}\right), 5.25(\mathrm{~d}, 1 \mathrm{H}, J=2.2 \mathrm{~Hz}$, $\left.\mathrm{N}\left(\mathrm{CH}_{2}\right)_{2}\right), 3.82\left(\mathrm{~s}, 1 \mathrm{H}, \mathrm{N}\left(\mathrm{CH}_{2}\right)_{2}\right), 3.78\left(\mathrm{~s}, 1 \mathrm{H}, \mathrm{N}\left(\mathrm{CH}_{2}\right)_{2}\right)$ 3.21 (hept, $\left.2 \mathrm{H}, J=6.7 \mathrm{~Hz}, \mathrm{CH}\left(\mathrm{CH}_{3}\right)_{2}\right), 3.03$ (hept, $2 \mathrm{H}, J=$ $\left.6.8 \mathrm{~Hz}, \mathrm{CH}\left(\mathrm{CH}_{3}\right)_{2}\right), 2.86$ (hept, $\left.2 \mathrm{H}, J=6.8 \mathrm{~Hz}, \mathrm{CH}\left(\mathrm{CH}_{3}\right)_{2}\right)$, 2.39 (hept, $\left.2 \mathrm{H}, J=6.8 \mathrm{~Hz}, \mathrm{CH}\left(\mathrm{CH}_{3}\right)_{2}\right), 1.74(\mathrm{~d}, 6 \mathrm{H}, J=6.7$ $\left.\mathrm{Hz}, \mathrm{CH}\left(\mathrm{CH}_{3}\right)_{2}\right), 1.52\left(\mathrm{~d}, 6 \mathrm{H}, J=6.7 \mathrm{~Hz}, \mathrm{CH}\left(\mathrm{CH}_{3}\right)_{2}\right), 1.28(\mathrm{~d}$, $\left.6 \mathrm{H}, J=6.8 \mathrm{~Hz}, \mathrm{CH}\left(\mathrm{CH}_{3}\right)_{2}\right), 1.21(\mathrm{~d}, 6 \mathrm{H}, J=6.9 \mathrm{~Hz}$, $\left.\mathrm{CH}\left(\mathrm{CH}_{3}\right)_{2}\right), 1.12\left(\mathrm{~d}, 6 \mathrm{H}, J=6.8 \mathrm{~Hz}, \mathrm{CH}\left(\mathrm{CH}_{3}\right)_{2}\right), 1.01(\mathrm{~d}$, $\left.6 \mathrm{H}, J=6.9 \mathrm{~Hz}, \mathrm{CH}\left(\mathrm{CH}_{3}\right)_{2}\right), 0.99(\mathrm{~d}, 6 \mathrm{H}, J=6.8 \mathrm{~Hz}$, $\left.\mathrm{CH}\left(\mathrm{CH}_{3}\right)_{2}\right), 0.88\left(\mathrm{~d}, 6 \mathrm{H}, J=6.8 \mathrm{~Hz}, \mathrm{CH}\left(\mathrm{CH}_{3}\right)_{2}\right) .{ }^{13} \mathrm{C} \mathrm{NMR}$ : $\delta_{\mathrm{C}}\left(\mathrm{C}_{6} \mathrm{D}_{6}, 100.64 \mathrm{MHz}\right) 193.70(\mathrm{~d}, J=71.7 \mathrm{~Hz}, \mathrm{Rh}-\mathrm{CO})$, $187.40(\mathrm{~d}, J=75.7 \mathrm{~Hz}, \mathrm{Rh}-\mathrm{CO}), 173.74(\mathrm{~d}, J=44.5 \mathrm{~Hz}$, $\left.\mathrm{C}_{\text {carbene }}\right), 155.68\left(\mathrm{C}_{\mathrm{q} T \mathrm{Tr}}\right), 146.84\left(\mathrm{ArC}_{\mathrm{q}}\right), 146.77\left(\mathrm{ArC}_{\mathrm{q}}\right)$ $145.23\left(\mathrm{ArC}_{\mathrm{q}}\right), 144.29\left(\mathrm{ArC}_{\mathrm{q}}\right), 135.71\left(\mathrm{ArC}_{\mathrm{q}}\right), 132.06$ $(\mathrm{ArCH}), 131.51\left(\mathrm{ArC}_{\mathrm{q}}\right), 131.22(\mathrm{ArCH}), 125.42(\mathrm{ArCH})$, $124.54(\mathrm{ArCH}), 123.96(\mathrm{ArCH}), 123.87(\mathrm{ArCH}), 57.65$ $\left(\mathrm{N}\left(\mathrm{CH}_{2}\right)_{2}\right), 29.26\left(\mathrm{CH}\left(\mathrm{CH}_{3}\right)_{2}\right), 29.29\left(\mathrm{CH}\left(\mathrm{CH}_{3}\right)_{2}\right), 29.08$ $\left(\mathrm{CH}\left(\mathrm{CH}_{3}\right)_{2}\right), 28.99\left(\mathrm{CH}\left(\mathrm{CH}_{3}\right)_{2}\right), 26.91\left(\mathrm{CH}\left(\mathrm{CH}_{3}\right)_{2}\right), 25.97$ $\left(\mathrm{CH}\left(\mathrm{CH}_{3}\right)_{2}\right), 25.56\left(\mathrm{CH}\left(\mathrm{CH}_{3}\right)_{2}\right), 25.50\left(\mathrm{CH}\left(\mathrm{CH}_{3}\right)_{2}\right), 24.55$ $\left(\mathrm{CH}\left(\mathrm{CH}_{3}\right)_{2}\right), 23.38\left(\mathrm{CH}\left(\mathrm{CH}_{3}\right)_{2}\right), 22.77\left(\mathrm{CH}\left(\mathrm{CH}_{3}\right)_{2}\right), 22.73$ $\left(\mathrm{CH}\left(\mathrm{CH}_{3}\right)_{2}\right)$. HRMS (FIA-ESI): calcd for $\mathrm{C}_{57} \mathrm{H}_{72} \mathrm{~N}_{7} \mathrm{O}_{3} \mathrm{Rh}_{2}$ $[\mathrm{M}-\mathrm{Cl}]^{+}: 1108.3801$; found: 1108.3755 and also $\mathrm{C}_{56} \mathrm{H}_{72} \mathrm{~N}_{7} \mathrm{O}_{2} \mathrm{Rh}_{2}[\mathrm{M}-\mathrm{Cl}-\mathrm{CO}]^{+}:$1080.3852; found: 1080.5378 and also $\mathrm{C}_{55} \mathrm{H}_{72} \mathrm{~N}_{7} \mathrm{ORh}[\mathrm{M}-\mathrm{Cl}-2 \mathrm{CO}-$ $\mathrm{Rh}]^{+}$: 949.4847; found: 949.4938. FTIR $\nu_{\mathrm{CO}}\left(\mathrm{CH}_{2} \mathrm{Cl}_{2}\right): 2019$, $1981 \mathrm{~cm}^{-1}$.

Synthesis of $8 \mathrm{~b}\left[\mathrm{Rh}(\mathrm{CO})\left(\mathrm{C}^{\mathrm{H}} \mathrm{NC}\right)\right]\left(\mathrm{PF}_{6}\right)$ (via in Situ Deprotonation). To a Schlenk tube loaded with $\left[\mathrm{H}_{2}\left(\mathbf{C}^{\mathrm{H}} \mathrm{NC}\right)\right]\left(\mathrm{PF}_{6}\right)(185 \mathrm{mg}, 0.17 \mathrm{mmol}), \mathrm{KHMDS}(65 \mathrm{mg}$, $0.33 \mathrm{mmol})$, and $\left[\mathrm{Rh}(\mathrm{CO})_{2} \mathrm{Cl}\right]_{2}(58 \mathrm{mg}, 0.15 \mathrm{mmol}),-78{ }^{\circ} \mathrm{C}$ anhydrous THF (ca. $50 \mathrm{~mL}$ ) was added, followed by stirring the reaction mixture for $30 \mathrm{~min}$ at the same temperature. The septum was removed and the reaction vessel was sealed. The reaction mixture was stirred overnight while warming up to RT. The reaction mixture turned from dark brown to yelloworange upon overnight reaction. The solvent was removed under reduced pressure, and the reaction mixture was washed with hexane. Extraction with diethyl ether and dichloromethane followed. NMR analysis showed that both fractions contained a mixture of complexes $8 \mathbf{a}\left[\mathrm{Rh}_{2}(\mathrm{CO})_{3} \mathrm{Cl}(\mu\right.$-CNC $\left.)\right]$ and $\mathbf{8 b}\left[\mathrm{Rh}(\mathrm{CO})\left(\mathbf{C}^{\mathrm{H}} \mathbf{N C}\right)\right]\left(\mathrm{PF}_{6}\right)$, with $\mathbf{8 a}$ being the major product (ca. $70 \%$ ) and $\mathbf{8 b}$ the minor product (ca. 30\%), based on NMR intensity (see Figures S31 and S32). Attempts to separate the two complexes were unsuccessful.
${ }^{1} \mathrm{H}$ NMR: $\delta_{\mathrm{H}}\left(\mathrm{C}_{6} \mathrm{D}_{6}, 500.13 \mathrm{MHz}\right) 7.14\left(\mathrm{~m}, 4 \mathrm{H}, \mathrm{ArH}_{\text {Dipp }}\right)$, 6.99 (d, $4 \mathrm{H}, J=7.2,7.5 \mathrm{~Hz}, \mathrm{ArH}_{\text {Dipp }}$ ), 6.95 (d, $4 \mathrm{H}, J=7.6,7.6$ $\left.\mathrm{Hz}, \mathrm{ArH}_{\text {Dipp }}\right), 6.52$ (pent, $\left.1 \mathrm{H}, J=6.4 \mathrm{~Hz}, \mathrm{NH}\left(\mathrm{CH}_{2}\right)_{2}\right), 3.94$ (d, $\left.1 \mathrm{H}, J=5.8 \mathrm{~Hz}, \mathrm{NH}\left(\mathrm{CH}_{2}\right)_{2}\right), 3.91(\mathrm{~d}, 1 \mathrm{H}, J=5.6 \mathrm{~Hz}$, $\left.\mathrm{NH}\left(\mathrm{CH}_{2}\right)_{2}\right), 3.27\left(\mathrm{~s}, 1 \mathrm{H}, \mathrm{NH}\left(\mathrm{CH}_{2}\right)_{2}\right), 3.26(\mathrm{~s}, 1 \mathrm{H}, \mathrm{NH}-$ $\left.\left(\mathrm{CH}_{2}\right)_{2}\right), 3.28$ (hept, $\left.2 \mathrm{H}, J=7.0 \mathrm{~Hz}, \mathrm{CH}\left(\mathrm{CH}_{3}\right)_{2}\right), 2.92$ (hept, $\left.2 \mathrm{H}, J=6.8 \mathrm{~Hz}, \mathrm{CH}\left(\mathrm{CH}_{3}\right)_{2}\right), 2.76($ hept, $2 \mathrm{H}, J=6.9 \mathrm{~Hz}$, $\left.\mathrm{CH}\left(\mathrm{CH}_{3}\right)_{2}\right), 2.24$ (hept, $\left.2 \mathrm{H}, \mathrm{J}=6.7 \mathrm{~Hz}, \mathrm{CH}\left(\mathrm{CH}_{3}\right)_{2}\right), 1.70(\mathrm{~d}$, $\left.12 \mathrm{H}, J=6.5 \mathrm{~Hz}, \mathrm{CH}\left(\mathrm{CH}_{3}\right)_{2}\right), 1.20(\mathrm{dd}, 24 \mathrm{H}, J=6.8,6.6 \mathrm{~Hz}$, $\left.\mathrm{CH}\left(\mathrm{CH}_{3}\right)_{2}\right), 1.08\left(\mathrm{~d}, 12 \mathrm{H}, J=6.9 \mathrm{~Hz}, \mathrm{CH}\left(\mathrm{CH}_{3}\right)_{2}\right) .{ }^{13} \mathrm{C} \mathrm{NMR}$ : $\delta_{\mathrm{C}}\left(\mathrm{C}_{6} \mathrm{D}_{6}, 125.31 \mathrm{MHz}\right) 194.94(\mathrm{~d}, J=68.1 \mathrm{~Hz}, \mathrm{Rh}-\mathrm{CO})$, $178.73\left(\mathrm{~d}, J=44.1 \mathrm{~Hz}, \mathrm{C}_{\text {carbene }}\right), 152.15\left(\mathrm{C}_{\mathrm{q} T \mathrm{rz}}\right), 147.31$ $\left(\operatorname{ArC}_{\mathrm{q}}\right), 147.29\left(\operatorname{ArC}_{\mathrm{q}}\right) 144.89\left(\operatorname{ArC}_{\mathrm{q}}\right), 144.34\left(\operatorname{ArC}_{\mathrm{q}}\right), 135.51$ $\left(\mathrm{ArC}_{\mathrm{q}}\right), 132.33(\mathrm{ArCH}), 131.26\left(\mathrm{ArC}_{\mathrm{q}}\right), 131.07(\mathrm{ArCH})$, $125.60(\mathrm{ArCH}), 124.86(\mathrm{ArCH}), 123.90(\mathrm{ArCH}), 123.43$ $(\mathrm{ArCH}), 49.88\left(\mathrm{~N}\left(\mathrm{CH}_{2}\right)_{2}\right), 29.36\left(\mathrm{CH}\left(\mathrm{CH}_{3}\right)_{2}\right), 29.25(\mathrm{CH}-$ $\left.\left(\mathrm{CH}_{3}\right)_{2}\right), 29.20\left(\mathrm{CH}\left(\mathrm{CH}_{3}\right)_{2}\right), 28.08\left(\mathrm{CH}\left(\mathrm{CH}_{3}\right)_{2}\right), 26.27$ $\left(\mathrm{CH}\left(\mathrm{CH}_{3}\right)_{2}\right), 25.32\left(\mathrm{CH}\left(\mathrm{CH}_{3}\right)_{2}\right), 24.85\left(\mathrm{CH}\left(\mathrm{CH}_{3}\right)_{2}\right), 24.56$ $\left(\mathrm{CH}\left(\mathrm{CH}_{3}\right)_{2}\right), 24.25\left(\mathrm{CH}\left(\mathrm{CH}_{3}\right)_{2}\right), 23.51\left(\mathrm{CH}\left(\mathrm{CH}_{3}\right)_{2}\right), 23.24$ $\left(\mathrm{CH}\left(\mathrm{CH}_{3}\right)_{2}\right), 23.10\left(\mathrm{CH}\left(\mathrm{CH}_{3}\right)_{2}\right) .{ }^{19} \mathrm{~F}$ NMR: $\delta_{\mathrm{F}}\left(\mathrm{C}_{6} \mathrm{D}_{6}\right.$, $470.59 \mathrm{MHz})-71.59\left(\mathrm{~d}, J=714.3 \mathrm{~Hz}, \mathrm{PF}_{6}\right) \cdot{ }^{31} \mathrm{P}$ NMR: $\delta_{\mathrm{P}}$ $\left(\mathrm{C}_{6} \mathrm{D}_{6}, 202.46 \mathrm{MHz}\right)-141.46$ (sept, $J=713.7 \mathrm{~Hz}, \mathbf{P F}_{6}$ ). HRMS (FIA-ESI): calcd for $\mathrm{C}_{54} \mathrm{H}_{73} \mathrm{~N}_{7} \mathrm{Rh}\left[\mathrm{M}-\mathrm{CO}-\mathrm{PF}_{6}\right]^{+}$: 950.4926; found: 950.3512. FTIR $\nu_{\mathrm{CO}}\left(\mathrm{CH}_{2} \mathrm{Cl}_{2}\right): 2019$ or $1981 \mathrm{~cm}^{-1}$ (overlapping with $\nu_{\mathrm{CO}}$ of $\mathbf{8 a}$ ).

Synthesis of $8 \mathrm{~b}\left[\mathrm{Rh}(\mathrm{CO})\left(\mathrm{C}^{\mathrm{H}} \mathrm{NC}\right)\right]\left(\mathrm{PF}_{6}\right)$ (via Transmetallation from Silver). The entitled compound was obtained in two steps via transmetallation reaction from its corresponding bimetallic silver derivative $9\left[\mathrm{Ag}_{2} \mathrm{Cl}_{2}(\mu\right.$-CNC)$]$ (see vida infra), which was prepared following a reported method. ${ }^{9 \mathrm{c}}$ To a Schlenk tube loaded with $\left[\mathrm{H}_{2}\left(\mathbf{C}^{\mathrm{H}} \mathbf{N C}\right)\right]\left(\mathrm{PF}_{6}\right)$ (731 mg, $0.66 \mathrm{mmol}), \mathrm{KCl}(122 \mathrm{mg}, 1.64 \mathrm{mmol})$, and $\mathrm{Ag}_{2} \mathrm{O}$ $(305 \mathrm{mg}, 1.32 \mathrm{mmol})$ was added acetonitrile (ca. $50 \mathrm{~mL}$ ) and stirred in a dark environment for 3 days. The reaction mixture was filtered. The filtrate was collected and evaporated to dryness under vacuum to perform a cannula filtration with dichloromethane. After cannula filtration and evaporation of the solvent under reduced pressure, compound $9\left[\mathrm{Ag}_{2} \mathrm{Cl}_{2}(\mu\right.$ $\mathrm{CNC})](619 \mathrm{mg}, 0.56 \mathrm{mmol}, 85 \%)$ was obtained as a pure white solid.

${ }^{1} \mathrm{H}$ NMR: $\delta_{\mathrm{H}}\left(\mathrm{CD}_{2} \mathrm{Cl}_{2}, 500.13 \mathrm{MHz}\right) 7.56(\mathrm{~m}, 4 \mathrm{H}$, $\left.\operatorname{ArH}_{\text {Dipp }}\right), 7.34\left(\mathrm{~m}, 8 \mathrm{H}, \operatorname{ArH}_{\text {Dipp }}\right), 3.75(\mathrm{~d}, 4 \mathrm{H}, J=6.9 \mathrm{~Hz}$, $\left.\mathrm{NH}\left(\mathrm{CH}_{2}\right)_{2}\right), 2.71\left(\mathrm{~s}, 1 \mathrm{H}, \mathrm{NH}\left(\mathrm{CH}_{2}\right)_{2}\right), 2.35$ (sept, $4 \mathrm{H}, J=6.6$ $\left.\mathrm{Hz}, \mathrm{CH}\left(\mathrm{CH}_{3}\right)_{2}\right), 2.26$ (sept, $\left.4 \mathrm{H}, J=6.3 \mathrm{~Hz}, \mathrm{CH}\left(\mathrm{CH}_{3}\right)_{2}\right), 1.39$ $\left(\mathrm{d}, 3 \mathrm{H}, J=6.7 \mathrm{~Hz}, \mathrm{CH}\left(\mathrm{CH}_{3}\right)_{2}\right), 1.34(\mathrm{~d}, 3 \mathrm{H}, J=6.6 \mathrm{~Hz}$, $\left.\mathrm{CH}\left(\mathrm{CH}_{3}\right)_{2}\right), 1.15\left(\mathrm{~m}, 42 \mathrm{H}, \mathrm{CH}\left(\mathrm{CH}_{3}\right)_{2}\right) .{ }^{13} \mathrm{C}$ NMR: $\delta_{\mathrm{C}}$ $\left(\mathrm{CD}_{2} \mathrm{Cl}_{2}, 125.31 \mathrm{MHz}\right) 149.82\left(\mathrm{C}_{\text {carbene }}\right), 149.68\left(\mathrm{C}_{\text {carbene }}\right)$, $145.99\left(\mathrm{C}_{\mathrm{q} T \mathrm{Tr}}\right), 145.85\left(\mathrm{C}_{\mathrm{q} T \mathrm{Trz}}\right), 145.34\left(\mathrm{ArC}_{\mathrm{q}}\right), 145.12$ $\left(\mathrm{ArC}_{\mathrm{q}}\right), 145.01\left(\mathrm{ArC}_{\mathrm{q}}\right), 135.84\left(\mathrm{ArC}_{\mathrm{q}}\right), 132.34(\mathrm{ArCH})$, $131.65(\mathrm{ArCH}), 131.53(\mathrm{ArCH}), 129.66\left(\mathrm{ArC}_{\mathrm{q}}\right), 125.11$ $(\mathrm{ArCH}), 124.79\left(\mathrm{ArC}_{\mathrm{q}}\right), 124.48(\mathrm{ArCH}), 124.27(\mathrm{ArCH})$, $45.64\left(\mathrm{NH}\left(\mathrm{CH}_{2}\right)_{2}\right), 29.28\left(\mathrm{CH}\left(\mathrm{CH}_{3}\right)_{2}\right), 29.06\left(\mathrm{CH}\left(\mathrm{CH}_{3}\right)_{2}\right)$, $28.93\left(\mathrm{CH}\left(\mathrm{CH}_{3}\right)_{2}\right), 28.58\left(\mathrm{CH}\left(\mathrm{CH}_{3}\right)_{2}\right), 25.74\left(\mathrm{CH}\left(\mathrm{CH}_{3}\right)_{2}\right)$, $25.67\left(\mathrm{CH}\left(\mathrm{CH}_{3}\right)_{2}\right), 25.66\left(\mathrm{CH}\left(\mathrm{CH}_{3}\right)_{2}\right), 24.69\left(\mathrm{CH}\left(\mathrm{CH}_{3}\right)_{2}\right)$, $24.63\left(\mathrm{CH}\left(\mathrm{CH}_{3}\right)_{2}\right), 24.52\left(\mathrm{CH}\left(\mathrm{CH}_{3}\right)_{2}\right), 23.91\left(\mathrm{CH}\left(\mathrm{CH}_{3}\right)_{2}\right)$, $23.10\left(\mathrm{CH}\left(\mathrm{CH}_{3}\right)_{2}\right)$. HRMS (FIA-ESI): calcd for $\left[\mathrm{C}_{54} \mathrm{H}_{76} \mathrm{~N}_{7} \mathrm{Cl}_{2} \mathrm{Ag}_{2}\right]$ 1106.3403; found: 1106.3446 .

To a Schlenk tube loaded with $9\left[\mathrm{Ag}_{2} \mathrm{Cl}_{2}(\mu\right.$-CNC) $]$ (135 $\mathrm{mg}, 0.12 \mathrm{mmol}), \mathrm{KPF}_{6}(45 \mathrm{mg}, 0.24 \mathrm{mmol})$, and [Rh$\left.(\mathrm{CO})_{2} \mathrm{Cl}\right]_{2}(38 \mathrm{mg}, 0.10 \mathrm{mmol})$, dichloromethane $(\mathrm{ca} .50 \mathrm{~mL})$ was added. The reaction vessel was capped and the reaction was stirred overnight. The reaction mixture turned from brown to a murky khaki color upon overnight reaction. The solvent 
was removed under reduced pressure, and the reaction mixture was washed with cold hexane. Washing was continued with RT hexane, followed by extraction with diethyl ether, which resulted in the isolation of compound $\mathbf{8 b}\left[\mathrm{Rh}(\mathrm{CO})\left(\mathrm{C}^{\mathrm{H}} \mathrm{NC}\right)\right]$ $\left(\mathrm{PF}_{6}\right)$ as a yellow solid $(118 \mathrm{mg}, 0.11 \mathrm{mmol}, 88 \%)$.

${ }^{1} \mathrm{H}$ NMR: $\delta_{\mathrm{H}}\left(\mathrm{C}_{6} \mathrm{D}_{6}, 500.13 \mathrm{MHz}\right) 7.16\left(\mathrm{~m}, 6 \mathrm{H}, \mathrm{ArH}_{\text {Dipp }}\right)$, $7.10\left(\mathrm{dd}, 2 \mathrm{H}, J=7.8,7.8 \mathrm{~Hz}, \operatorname{ArH}_{\text {Dipp }}\right), 6.99$ (dd, 2H, $J=7.7$, $\left.7.7 \mathrm{~Hz}, \operatorname{ArH}_{\text {Dipp }}\right), 6.96\left(\mathrm{dd}, 2 \mathrm{H}, J=7.5,7.5 \mathrm{~Hz}, \mathrm{ArH}_{\text {Dipp }}\right), 6.51$ (pent, $\left.1 \mathrm{H}, J=7.4 \mathrm{~Hz}, \mathrm{NH}\left(\mathrm{CH}_{2}\right)_{2}\right), 3.94(\mathrm{dd}, 1 \mathrm{H}, J=6.0,6.0$ $\left.\mathrm{Hz}, \mathrm{NH}\left(\mathrm{CH}_{2}\right)_{2}\right), 3.91\left(\mathrm{dd}, 1 \mathrm{H}, J=6.0,5.8 \mathrm{~Hz}, \mathrm{NH}\left(\mathrm{CH}_{2}\right)_{2}\right)$, $3.29\left(\mathrm{~d}, 1 \mathrm{H}, J=9.2 \mathrm{~Hz}, \mathrm{NH}\left(\mathrm{CH}_{2}\right)_{2}\right), 3.26(\mathrm{~d}, 1 \mathrm{H}, J=9.2 \mathrm{~Hz}$, $\left.\mathrm{NH}\left(\mathrm{CH}_{2}\right)_{2}\right), 2.90$ (hept, $\left.2 \mathrm{H}, J=6.7 \mathrm{~Hz}, \mathrm{CH}\left(\mathrm{CH}_{3}\right)_{2}\right), 2.83$ (hept, $\left.2 \mathrm{H}, J=6.8 \mathrm{~Hz}, \mathrm{CH}\left(\mathrm{CH}_{3}\right)_{2}\right), 2.76$ (hept, $2 \mathrm{H}, J=6.9 \mathrm{~Hz}$, $\left.\mathrm{CH}\left(\mathrm{CH}_{3}\right)_{2}\right), 2.25$ (hept, $\left.2 \mathrm{H}, J=6.8 \mathrm{~Hz}, \mathrm{CH}\left(\mathrm{CH}_{3}\right)_{2}\right), 1.67$ $\left(\mathrm{dd}, 12 \mathrm{H}, J=6.6,6.7 \mathrm{~Hz}, \mathrm{CH}\left(\mathrm{CH}_{3}\right)_{2}\right), 1.29(\mathrm{~d}, 6 \mathrm{H}, J=6.8 \mathrm{~Hz}$, $\left.\mathrm{CH}\left(\mathrm{CH}_{3}\right)_{2}\right), 1.18\left(\mathrm{dd}, 12 \mathrm{H}, J=6.9,6.8 \mathrm{~Hz}, \mathrm{CH}\left(\mathrm{CH}_{3}\right)_{2}\right), 1.06$ $\left(\mathrm{d}, 6 \mathrm{H}, J=6.9 \mathrm{~Hz}, \mathrm{CH}\left(\mathrm{CH}_{3}\right)_{2}\right), 0.98(\mathrm{dd}, 12 \mathrm{H}, J=6.8,6.8 \mathrm{~Hz}$, $\left.\mathrm{CH}\left(\mathrm{CH}_{3}\right)_{2}\right) .{ }^{13} \mathrm{C}$ NMR: $\delta_{\mathrm{C}}\left(\mathrm{C}_{6} \mathrm{D}_{6}, 125.31 \mathrm{MHz}\right) 192.33$ (d, $J$ $=81.5 \mathrm{~Hz}, \mathrm{Rh}-\mathrm{CO}), 178.67\left(\mathrm{~d}, J=44.2 \mathrm{~Hz}, \mathrm{C}_{\text {carbene }}\right), 152.19$ $\left(\mathrm{C}_{\mathrm{q} \text { Trz }}\right), 147.22\left(\operatorname{ArC}_{\mathrm{q}}\right), 147.18\left(\operatorname{ArC}_{\mathrm{q}}\right) 144.92\left(\operatorname{ArC}_{\mathrm{q}}\right), 144.39$ $\left(\mathrm{ArC}_{\mathrm{q}}\right), 135.50\left(\mathrm{ArC}_{\mathrm{q}}\right), 132.38(\mathrm{ArCH}), 131.26(\mathrm{ArCH})$, $131.04\left(\mathrm{ArC}_{\mathrm{q}}\right), 125.57(\mathrm{ArCH}), 124.83(\mathrm{ArCH}), 123.98$ $(\mathrm{ArCH}), 123.46(\mathrm{ArCH}), 49.88\left(\mathrm{~N}\left(\mathrm{CH}_{2}\right)_{2}\right), 29.35(\mathrm{CH}-$ $\left.\left(\mathrm{CH}_{3}\right)_{2}\right), 29.23\left(\mathrm{CH}\left(\mathrm{CH}_{3}\right)_{2}\right), 29.09\left(\mathrm{CH}\left(\mathrm{CH}_{3}\right)_{2}\right), 29.09$ $\left(\mathrm{CH}\left(\mathrm{CH}_{3}\right)_{2}\right), 26.26\left(\mathrm{CH}\left(\mathrm{CH}_{3}\right)_{2}\right), 25.33\left(\mathrm{CH}\left(\mathrm{CH}_{3}\right)_{2}\right), 24.87$ $\left(\mathrm{CH}\left(\mathrm{CH}_{3}\right)_{2}\right), 24.56\left(\mathrm{CH}\left(\mathrm{CH}_{3}\right)_{2}\right), 24.26\left(\mathrm{CH}\left(\mathrm{CH}_{3}\right)_{2}\right), 23.51$ $\left(\mathrm{CH}\left(\mathrm{CH}_{3}\right)_{2}\right), 23.23\left(\mathrm{CH}\left(\mathrm{CH}_{3}\right)_{2}\right), 23.12\left(\mathrm{CH}\left(\mathrm{CH}_{3}\right)_{2}\right) .{ }^{19} \mathrm{~F}$ NMR: $\delta_{\mathrm{F}}\left(\mathrm{C}_{6} \mathrm{D}_{6}, 470.59 \mathrm{MHz}\right)-71.23\left(\mathrm{~d}, J=713.0 \mathrm{~Hz}, \mathrm{PF}_{6}\right)$. ${ }^{31} \mathrm{P}$ NMR: $\delta_{\mathrm{P}}\left(\mathrm{C}_{6} \mathrm{D}_{6}, 202.46 \mathrm{MHz}\right)-143.27$ (sept, $J=713.0$ $\mathrm{Hz}, \mathrm{PF}_{6}$ ). HRMS (FIA-ESI): calcd for $\mathrm{C}_{55} \mathrm{H}_{73} \mathrm{~N}_{7} \mathrm{ORh}[\mathrm{M}-$ $\left.\mathrm{PF}_{6}\right]^{+}$: 950.4931; found: 950.4931. FTIR $\nu_{\mathrm{CO}}\left(\mathrm{CH}_{2} \mathrm{Cl}_{2}\right): 1974$ $\mathrm{cm}^{-1}$. FTIR $\nu_{\mathrm{NH}}\left(\mathrm{CH}_{2} \mathrm{Cl}_{2}\right): 3256 \mathrm{~cm}^{-1}$.

\section{ASSOCIATED CONTENT}

\section{S Supporting Information}

The Supporting Information is available free of charge on the ACS Publications website at DOI: 10.1021/acsomega.9b00514.

Synthesis and characterization of $\left[\mathrm{H}_{2}(\mathbf{C O C})\right]\left(\mathrm{PF}_{6}\right)_{2}$, $\left[\mathrm{H}_{2}\left(\mathbf{C}^{\mathrm{Boc}} \mathbf{N C}\right)\right]\left(\mathrm{PF}_{6}\right)_{2}$, and $\left[\mathrm{H}_{2}\left(\mathbf{C}^{\mathrm{H}} \mathbf{N C}\right)\right]\left(\mathrm{PF}_{6}\right)_{2} ; \mathrm{NMR}$ spectra of ligand precursor salts: $\left[\mathrm{H}_{2}(\mathbf{C O C})\right]\left(\mathrm{PF}_{6}\right)_{2}$, $\left[\mathrm{H}_{2}\left(\mathbf{C}^{\mathrm{Boc}} \mathbf{N C}\right)\right]\left(\mathrm{PF}_{6}\right)_{2}$, and $\left[\mathrm{H}_{2}\left(\mathbf{C}^{\mathrm{H}} \mathbf{N C}\right)\right]\left(\mathrm{PF}_{6}\right)_{2} ;$ and details of complexes 1a, 1b, 2a, 2b, 3a, 4a, 4b, 5, 6, $7 a, 7 b, 8 a, 8 b$, and 9 for the crystal structure determinations of $\left[\mathrm{H}_{2}(\mathbf{C O C})\right]\left(\mathrm{PF}_{6}\right)_{2},\left[\mathrm{H}_{2}\left(\mathbf{C}^{\mathbf{B o c}} \mathbf{N C}\right)\right]$ $\left(\mathrm{PF}_{6}\right)_{2},\left[\mathrm{H}_{2}\left(\mathrm{C}^{\mathrm{H}} \mathrm{NC}\right)\right]\left(\mathrm{PF}_{6}\right)_{2}, \mathbf{1 b}, \mathbf{2 a}, \mathbf{2 b}, \mathbf{3 a}, \mathbf{4 a}, \mathbf{6}, \mathbf{7 b}$, and $8 \mathbf{a}$ (PDF)

Crystallographic data (CIF)

\section{Accession Codes}

CCDC numbers $1874026-1874035$ and 1890712 contain the supporting crystallographic data for this paper. These data can be obtained free of charge via www.ccdc.cam.ac.uk/data request/cif, by emailing data_request@ccdc.cam.ac.uk, or by contacting The Cambridge Crystallographic Data Centre, 12 Union Road, Cambridge CB2 1EZ, U.K.; fax: +44 1223 336033.

\section{AUTHOR INFORMATION}

\section{Corresponding Authors}

*E-mail: daniela.bezuidenhout@wits.ac.za (D.I.B.).

*E-mail: guisado@uji.es (G.G.-B.).

\section{ORCID}

Daniela I. Bezuidenhout: 0000-0001-7776-8227 Gregorio Guisado-Barrios: 0000-0002-0154-9682 Notes

The authors declare no competing financial interest.

\section{ACKNOWLEDGMENTS}

The authors sincerely thank Dr. Hendrik Henning, University of the Witwatersrand, for recording of the low-temperature NMR experiments. L.C.T., I.S., W.J.L., D.I.B., and M.A.F. acknowledge the National Research Foundation, South Africa (NRF 115642; NRF 94784; NRF 100119; NRF 111705), and Sasol Technology R\&D Pty. Ltd. (South Africa), for financial support (D.I.B.). G.G.-B. acknowledges MINECO for a "Juan de la Cierva Fellowship" (G.G.-B., IJCI-2015-23407)

\section{REFERENCES}

(1) For selected reviews on NHCs: (a) Cheng, J.; Wang, L.; Wang, P.; Deng, L. High-Oxidation-State 3d Metal ( $\mathrm{Ti}-\mathrm{Cu})$ Complexes with N-Heterocyclic Carbene Ligation. Chem. Rev. 2018, 118, 99309987. (b) Gan, M.-M.; Liu, J.-Q.; Zhang, L.; Wang, Y.-Y.; Hahn, F. E.; Han, Y.-F. Preparation and Post-Assembly Modification of Metallosupramolecular Assemblies from Poly(N-Heterocyclic Carbene) Ligands. Chem. Rev. 2018, 118, 9587-9641. (c) Peris, E. Smart NHeterocyclic Carbene Ligands in Catalysis. Chem. Rev. 2018, 118, 9988-10031. (d) Hopkinson, M. N.; Richter, C.; Schedler, M.; Glorius, F. An overview of N-heterocyclic carbenes. Nature 2014, 485-496. (e) Arduengo, A. J.; Bertrand, G. Carbenes Introduction. Chem. Rev. 2009, 109, 3209-3210. (f) Kunz, D.; Flaig, K. S. The coordinative flexibility of rigid phenanthroline-analogous di(NHC)ligands. Coord. Chem. Rev. 2018, 377, 73-85.

(2) (a) Melaimi, M.; Jazzar, R.; Soleilhavoup, M.; Bertrand, G. Cyclic (Alkyl)(amino)carbenes (CAACs): Recent Developments. Angew. Chem., Int. Ed. 2017, 56, 10046-10068. (b) Soleilhavoup, M.; Bertrand, G. Cyclic (alkyl)(amino)carbenes (CAACs): stable carbenes on the rise. Acc. Chem. Res. 2015, 48, 256-266.

(3) (a) Aldeco-Perez, E.; Rosenthal, A. J.; Donnadieu, B.; Parameswaran, P.; Frenking, G.; Bertrand, G. Isolation of a C5deprotonated imidazolium, a crystalline "abnormal" N-heterocyclic carbene. Science 2009, 326, 556-559. (b) Mathew, P.; Neels, A.; Albrecht, M. 1,2,3-Triazolylidenes as Versatile Abnormal Carbene Ligands for Late Transition Metals. J. Am. Chem. Soc. 2008, 130, 13534-13535. (c) Guisado-Barrios, G.; Bouffard, J.; Donnadieu, B.; Bertrand, G. Crystalline 1H-1,2,3-Triazol-5-ylidenes: New Stable Mesoionic Carbenes. Angew. Chem., Int. Ed. 2010, 49, 4759-4762. (d) Bouffard, J.; Keitz, B. K.; Tonner, R.; Guisado-Barrios, G.; Frenking, G.; Grubbs, R. H.; Bertrand, G. Synthesis of Highly Stable 1,3-Diaryl-1H-1,2,3-triazol-5-ylidenes and Their Applications in Ruthenium-Catalyzed Olefin Metathesis. Organometallics 2011, 30, 2617-2627. (e) Fernández, I.; Dyker, C. A.; DeHope, A.; Donnadieu, B.; Frenking, G.; Bertrand, G. Exocyclic delocalization at the expense of aromaticity in 3,5-bis(pi-donor) substituted pyrazolium ions and corresponding cyclic bent allenes. J. Am. Chem. Soc. 2009, 131, $11875-11881$.

(4) For selected reviews on Mesoionic 1,2,3-triazol-5-ylidenes (MICs): (a) Guisado-Barrios, G.; Soleilhavoup, M.; Bertrand, G. 1H-1,2,3-Triazol-5-ylidenes: Readily Available Mesoionic Carbenes. Acc. Chem. Res. 2018, 51, 3236-3244. (b) Vivancos, Á.; Segarra, C.; Albrecht, M. Mesoionic and Related Less Heteroatom-Stabilized NHeterocyclic Carbene Complexes: Synthesis, Catalysis, and Other Applications. Chem. Rev. 2018, 118, 9493-9586. (c) Marichev, K. O.; Patil, S. A.; Bugarin, A. Recent advances in the synthesis, structural diversity, and applications of mesoionic 1,2,3-triazol-5-ylidene metal complexes. Tetrahedron 2018, 74, 2523-2546. (d) Schweinfurth, D.; Hettmanczyk, L.; Suntrup, L.; Sarkar, B. Metal Complexes of ClickDerived Triazoles and Mesoionic Carbenes: Electron Transfer, Photochemistry, Magnetic Bistability, and Catalysis. Z. Anorg. Allg. 
Chem. 2017, 643, 554-584. (e) Donnelly, K. F.; Petronilho, A.; Albrecht, M. Application of 1,2,3-triazolylidenes as versatile NHCtype ligands: synthesis, properties, and application in catalysis and beyond. Chem. Commun. 2013, 49, 1145-1159.

(5) Guisado-Barrios, G.; Bouffard, J.; Donnadieu, B.; Bertrand, G. Bis(1,2,3-triazol-5-ylidenes) (i-bitz) as Stable 1,4-Bidentate Ligands Based on Mesoionic Carbenes (MICs). Organometallics 2011, 30, 6017-6021.

(6) (a) Huang, W.; Zhang, Y.-C.; Jin, R.; Chen, B.-L.; Chen, Z. Synthesis of Axially Chiral 1,2,3-Triazol-5-ylidene-Au(I) Complex and Its Application in Enantioselective [2 + 2] Cycloaddition of Alleneamides with Alkenes. Organometallics 2018, 37, 3196-3209. (b) Chábera, P.; Liu, Y.; Prakash, O.; Thyrhaug, E.; El Nahhas, A.; Honarfar, A.; Essén, S.; Fredin, L. A.; Harlang, T. C. B.; Kjær, K. S.; Handrup, K.; Ericson, F.; Tatsuno, H.; Morgan, K.; Schnadt, J.; Häggström, L.; Ericsson, T.; Sobkowiak, A.; Lidin, S.; Huang, P.; Styring, S.; Uhlig, J.; Bendix, J.; Lomoth, R.; Sundström, V.; Persson, P.; Wärnmark, K. A low-spin Fe(III) complex with 100-ps ligand- tometal charge transfer photoluminescence. Nature 2017, 543, 695699. (c) Schulze, B.; Escudero, D.; Friebe, C.; Siebert, R.; Görls, H.; Köhn, U.; Altuntas, E.; Baumgaertel, A.; Hager, M. D.; Winter, A.; Dietzek, B.; Popp, J.; Gonzalez, L.; Schubert, U. S. A Heteroleptic Bis(tridentate) Ruthenium(II) Complex of a Click-Derived Abnormal Carbene Pincer Ligand with Potential for Photosensitzer Application. Chem. - Eur. J. 2011, 17, 5494-5498. (d) Keske, E. C.; Zenkina, O. V.; Wang, R.; Crudden, C. M. Synthesis and structure of palladium 1,2,3-triazol-5-ylidene mesoionic carbene PEPPSI complexes and their catalytic applications in the mizoroki-heck reaction. Organometallics 2012, 31, 6215-6221. (e) Hohloch, S.; Suntrup, L.; Sarkar, B. Synthesis of Axially Chiral 1,2,3-Triazol-5-ylidene-Au(I) Complex and Its Application in Enantioselective [2 + 2] Cycloaddition of Alleneamides with Alkenes. Organometallics 2013, 32, 7376-7385. (f) Zamora, M. T.; Ferguson, M. J.; Cowie, M. Di-Mesoionic Carbene-Bridged Complexes of $\mathrm{Rh}_{2}, \mathrm{Ir}_{2}$, and $\mathrm{RhIr}$ : A Stepwise Metalation Strategy for the Synthesis of di-MIC-Bridged Mixed-Metal Systems. Organometallics 2012, 31, 5384-5395. (g) Kleinhans, G.; Hansmann, M. M.; Guisado-Barrios, G.; Liles, D. C.; Bertrand, G.; Bezuidenhout, D. I. Nucleophilic T-Shaped (LXL)Au(I)-Pincer Complexes: Protonation and Alkylation. J. Am. Chem. Soc. 2016, 138, 15873-15876. (h) Kleinhans, G.; Guisado-Barrios, G.; Peris, E.; Bezuidenhout, D. I. Ruthenium(II) pincer complexes featuring an anionic CNC bis(1,2,3-triazol-5-ylidene)carbazolide ligand coordinated in a meridional fashion. Polyhedron 2017, DOI: 10.1016/ j.poly.2017.07.010. (i) Kleinhans, G.; Guisado-Barrios, G.; Liles, D. C.; Bertrand, G.; Bezuidenhout, D. I. Chem. Commun. 2016, 52, 3504-3507. (j) Bezuidenhout, D. I.; Kleinhans, G.; Guisado-Barrios, G.; Liles, D. C.; Ung, G.; Bertrand, G. Isolation of a potassium bis(1,2,3-triazol-5-ylidene)carbazolide: A stabilizing pincer ligand for reactive late transition metal complexes. Chem. Commun. 2014, 50, 2431-2433. (k) Bezuidenhout, D. I.; Kleinhans, G.; Guisado-Barrios, G.; Liles, D. C.; Ung, G.; Bertrand, G. Isolation of a potassium bis(1,2,3-triazol-5-ylidene)carbazolide: a stabilizing pincer ligand for reactive late transition metal complexes. Chem. Commun. 2014, 50, 2431-2433.

(7) (a) Mejuto, C.; Guisado-Barrios, G.; Gusev, D.; Peris, E. First homoleptic MIC and heteroleptic NHC-MIC coordination cages from 1,3,5-triphenylbenzene-bridged tris-MIC and tris-NHC ligands. Chem. Commun. 2015, 51, 13914-13917. (b) Mejuto, C.; Royo, B.; Guisado-Barrios, G.; Peris, E. Rhodium, iridium and nickel complexes with a 1,3,5-triphenylbenzene tris-MIC ligand. Study of the electronic properties and catalytic activities. Beilstein J. Org. Chem. 2015, 11, 2584-2590. (c) Mendoza-Espinosa, D.; González-Olvera, R.; Negrón-Silva, G. E.; Angeles-Beltrán, D.; Suárez-Castillo, O. R.; Alvarez-Hernández, A.; Santillan, R. Phenoxy-Linked Mesoionic Triazol-5-ylidenes as Platforms for Multinuclear Transition Metal Complexes. Organometallics 2015, 34, 4529-4542. (d) Maity, R.; van der Meer, M.; Sarkar, B. Redox-active multinuclear Pd(II) complexes with bis- and tris-mesoionic carbenes. Dalton Trans. 2014, 44, 46-49. (e) Maity, R.; Mekic, A.; van der Meer, M.; Verma, A.; Sarkar, B.
Triply cyclometalated trinuclear iridium(III) and trinuclear palladium(II) complexes with a tri-mesoionic carbene ligand. Chem. Commun. 2015, 51, 15106-15109. (f) Petronilho, A.; Woods, J. A.; Bernhard, S.; Albrecht, M. Bimetallic iridium-carbene complexes with mesoionic triazolylidene ligands for water oxidation catalysis. Eur. J. Inorg. Chem. 2014, 4, 708-714.

(8) (a) Alig, L.; Fritz, M.; Schneider, S. First-Row Transition Metal (De)Hydrogenation Catalysis Based on Functional Pincer Ligands. Chem. Rev. 2019, 119, 2681-2751. (b) Kaithal, A.; Hölscher, M.; Leitner, W. Catalytic Hydrogenation of Cyclic Carbonates using Manganese Complexes. Angew. Chem., Int. Ed. 2018, 57, 1344913453. (c) Han, Z.; Rong, L.; Wu, J.; Zhang, L.; Wang, Z.; Ding, K. Catalytic Hydrogenation of Cyclic Carbonates: A Practical Approach from $\mathrm{CO}_{2}$ and Epoxides to Methanol and Diols. Angew. Chem., Int. Ed. 2012, 51, 13041-13045. (d) Gusev, D. G. Rethinking the Dehydrogenative Amide Synthesis. ACS Catal. 2017, 7, 6656-6662.

(9) (a) Vivancos, Á.; Albrecht, M. Influence of the Linker Length and Coordination Mode of (Di)Triazolylidene Ligands on the Structure and Catalytic Transfer Hydrogenation Activity of Iridium(III) Centers. Organometallics 2017, 36, 1580-1590. (b) Petronilho, A.; Woods, J. A.; Bernhard, S.; Albrecht, M. Bimetallic iridiumcarbene complexes with mesoionic triazolylidene ligands for water oxidation catalysis. Eur. J. Inorg. Chem. 2014, 2014, 708-714. (c) Andrew, R. E.; González-Sebastián, L.; Chaplin, A. B. NHC-based pincer ligands: carbenes with a bite. Dalton Trans. 2016, 45, 12991305. (d) Nguyen, T. V. Q.; Yoo, W.-J.; Kobayashi, S. Effective Formylation of Amines with Carbon Dioxide and Diphenylsilane Catalyzed by Chelating bis(tzNHC) Rhodium Complexes. Angew. Chem. 2015, 127, 9341-9344. (e) Li, L.; Cao, L.; Yan, X. Synthesis and Characterization of Palladium(II) CNC Pincer Complexes with Novel Bis(1,2,3-triazolylidene)amine Ligands. ChemistrySelect 2018, 3, 10706-10710 During our first submission of this report we became aware of an independent report of the synthesis of $\mathbf{L 2}$, prepared via an alternative route; and the pincer palladium complex thereof via transmetallation from silver .

(10) Mata, J. A.; Chianese, A. R.; Miecznikowski, J. R.; Poyatos, M.; Peris, E.; Faller, J. W.; Crabtree, R. H. Reactivity Differences in the Syntheses of Chelating N-Heterocyclic Carbene Complexes of Rhodium Are Ascribed to Ligand Anisotropy. Organometallics 2004, 23, 1253-1263.

(11) Sluijter, S. N.; Elsevier, C. J. Synthesis and Reactivity of Heteroditopic Dicarbene Rhodium(I) and Iridium(I) Complexes Bearing Chelating 1,2,3-Triazolylidene-Imidazolylidene Ligands. Organometallics 2014, 33, 6389-6397.

(12) (a) Zamora, M. T.; Ferguson, M. J.; Cowie, M. Di-Mesoionic Carbene-Bridged Complexes of $\mathrm{Rh}_{2}, \mathrm{Ir}_{2}$, and RhIr: A Stepwise Metalation Strategy for the Synthesis of di-MIC-Bridged Mixed-Metal Systems. Organometallics 2012, 31, 5384-5395. (b) Zamora, M. T.; Ferguson, M. J.; McDonald, R.; Cowie, M. Unsymmetrical Dicarbenes Based on N-Heterocyclic/Mesoionic Carbene Frameworks: A Stepwise Metalation Strategy for the Generation of a DicarbeneBridged Mixed-Metal Pd/Rh Complex. Organometallics 2012, 31, 5463-5477.

(13) Wang, H. M. J.; Lin, I. J. B. Facile Synthesis of Silver(I)Carbene Complexes. Useful Carbene Transfer Agents. Organometallics 1998, 17, 972-975.

(14) Tejel, C.; Ciriano, M. A.; Bordonaba, M.; López, J. A.; Lahoz, F. J.; Oro, L. A. Structural and Dynamic Studies on Amido-Bridged Rhodium and Iridium Complexes. Chem. - Eur. J. 2002, 8, 31283138.

(15) Yan, X.; Bouffard, J.; Guisado-Barrios, G.; Donnadieu, B.; Bertrand, G. Anionic 1,2,3-triazole-4,5-diylidene: a 1,2-dihapto ligand for the construction of bimetallic complexes. Chem. - Eur. J. 2012, 18, 14627-14631.

(16) (a) Nimitsiriwat, N.; Gibson, V. C.; Marshall, E. L.; Takolpuckdee, P.; Tomov, A. K.; White, A. J. P.; Williams, D. J.; Elsegood, M. R. J.; Dale, S. H. Mono- versus bis-chelate formation in triazenide and amidinate complexes of magnesium and zinc. Inorg. Chem. 2007, 46, 9988-9997. (b) Barrett, A. G. M.; Crimmin, M. R.; 
Hill, M. S.; Hitchcock, P. B.; Kociok-Kohn, G.; Procopiou, P. A. Triazenide complexes of the heavier alkaline earths: Synthesis, characterization, and suitability for hydroamination catalysis. Inorg Chem. 2008, 47, 7366-7376.

(17) (a) Mintz, C.; Walling, M. t-Butyl Hypochlorite. Org. Synth. 1969, 49, 9. (b) Wirschun, W.; Winkler, M.; Lutz, K.; Jochims, J. C. 1,3-Diaza-2-azoniaallene salts: Cycloadditions to alkynes, carbodiimides and cyanamides. J. Chem. Soc., Perkin Trans. 1 1998, 17551762.

(18) Strydom, I.; Guisado-Barrios, G.; Fernández, I.; Liles, D. C.; Peris, E.; Bezuidenhout, D. I. A hemilabile and cooperative N-Donorfunctionalised 1,2,3-Triazol-5-ylidene ligand for alkyne hydrothiolation reactions. Chem. - Eur. J. 2017, 23, 1393-1401 (Using an adapted method) .

(19) Giordano, G.; Crabtree, R. H. et al. Inorganic Syntheses: Reagents for Transition metal complex and Organometallic Syntheses; John Wiley \& Sons: Hoboken, 1991; Vol. 28, pp 88-90.

(20) McCleverty, J. A.; Wilkinson, G. et al. Inorganic Syntheses: Reagents for Transition metal complex and Organometallic Syntheses; John Wiley \& Sons: Hoboken, 1990; Vol. 28, pp 84-86.

(21) (a) Angelici, R. J., Ed.; Inorganic Syntheses: Reagents for Transition Metal Complex and Organometallic Syntheses; John Wiley \& Sons: Hoboken, 1990; Vol. 28. (b) Choudhury, J.; Poddler, S.; Roy, S. Cooperative Friedel-Crafts Catalysis in Heterobimetallic Regime: Alkylation of Aromatics by $\pi$-Activated Alcohols. J. Am. Chem. Soc. 2005, 127, 6162-6163. 